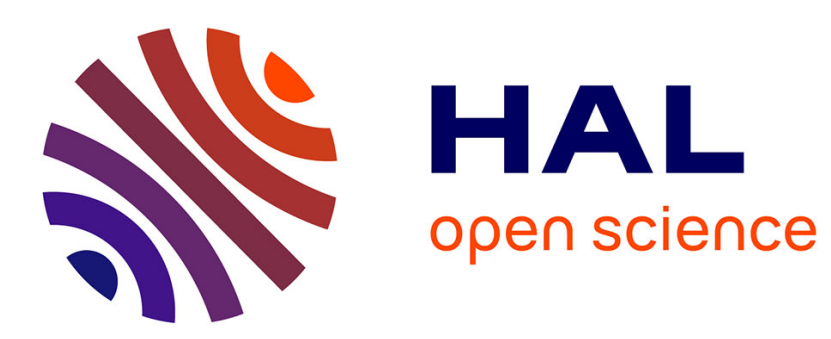

\title{
The Role of Monoanionic Aryl Pincer Ligands in the Stabilization of Group 14 Metallylenes
}

\author{
Noémi Deak, David Madec, Gabriela Nemes
}

\section{To cite this version:}

Noémi Deak, David Madec, Gabriela Nemes. The Role of Monoanionic Aryl Pincer Ligands in the Stabilization of Group 14 Metallylenes. European Journal of Inorganic Chemistry, 2020, 2020 (29), pp.2769-2790. 10.1002/ejic.202000409 . hal-02971229

\section{HAL Id: hal-02971229 \\ https://hal.science/hal-02971229}

Submitted on 21 Oct 2020

HAL is a multi-disciplinary open access archive for the deposit and dissemination of scientific research documents, whether they are published or not. The documents may come from teaching and research institutions in France or abroad, or from public or private research centers.
L'archive ouverte pluridisciplinaire HAL, est destinée au dépôt et à la diffusion de documents scientifiques de niveau recherche, publiés ou non, émanant des établissements d'enseignement et de recherche français ou étrangers, des laboratoires publics ou privés. 
The role of monoanionic aryl pincer ligands in the stabilization of group 14 metallylenes

\author{
Noémi Deak ${ }^{1,2}$, David Madec ${ }^{1 *}$, Gabriela Nemes ${ }^{2 *}$
}

${ }^{1}$ Dr. Noémi Deak, Dr. David Madec

Laboratoire Hétérochimie Fondamentale et Appliquée (UMR 5069), Université de Toulouse, CNRS, 118 Route de Narbonne, 31062 Toulouse Cedex 9 (France)

E-mail: madec@chimie.ups-tlse.fr

Website: www.lhfa.cnrs.fr

${ }^{2}$ Dr. Noémi Deak, Assoc. Prof. Dr. Gabriela Nemes

Universitatea Babeş-Bolyai, Facultatea de Chimie şi Inginerie Chimică, Departamentul de Chimie, str. Arany Janos, nr. 11, 400028, Cluj-Napoca (Romania)

E-mail: gabriela.nemes@ubbcluj.ro

Website: http://www.chem.ubbcluj.ro/pagini/anorganica/clcpe/

\title{
Table of content
}

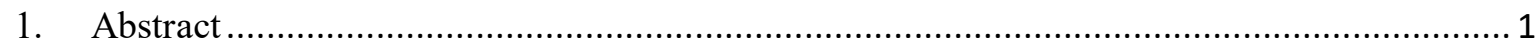

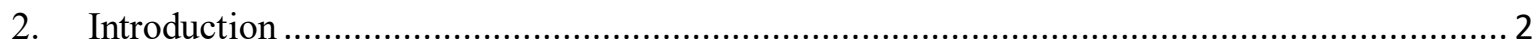

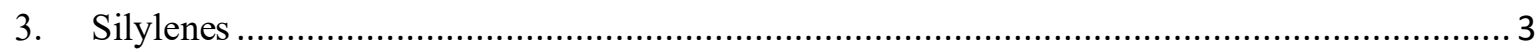

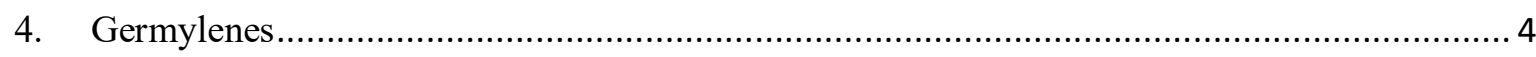

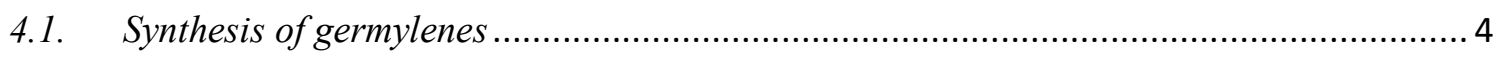

4.2. Physical-chemical and structural characterization of germylenes ................................. 5

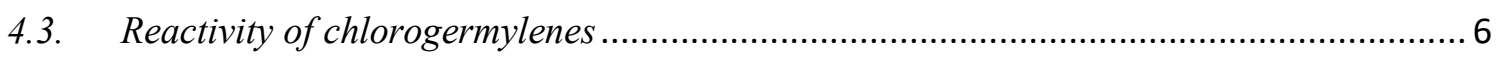

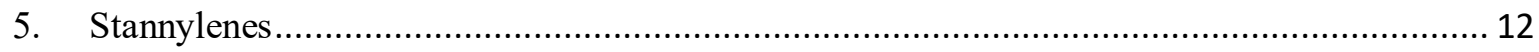

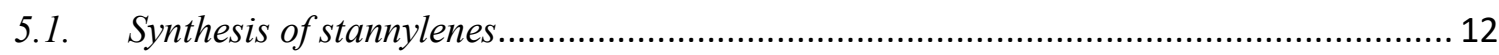

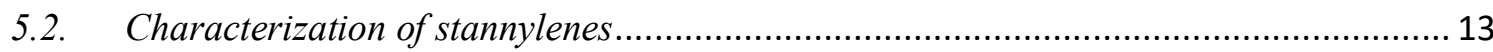

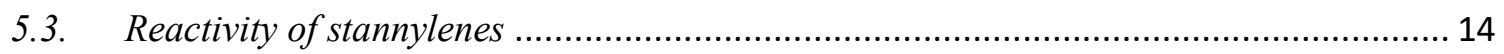

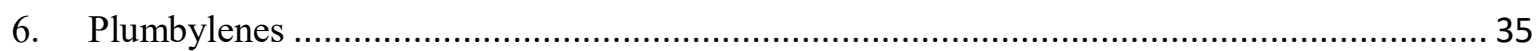

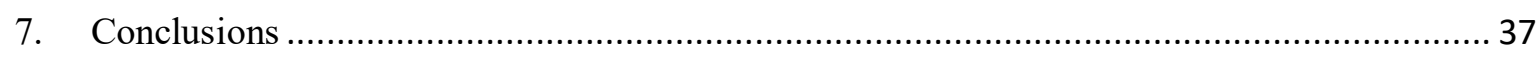

\section{Abstract}

Pincer ligands have an important role in stabilizing group 14 metallylenes. The particular structure of the aryl pincer ligands makes them a unique ligand platform. This review is focused on presenting the monoanionic aryl pincer-type ligand stabilized metallylenes, described so far in the literature, with focus on their synthesis, structural features and reactivity. Throughout this work, the close correlation between structure and reactivity is highlighted, as well as the manner in which this influences the stability of the compounds and their potential applications. 


\section{Introduction}

Metallylenes, the heavier analogues of carbene, represent a versatile class of compounds with a vast number of applications. Along the years of the development of these derivatives, a large number of ligands were developed in order to stabilize these highly reactive divalent species and to control their reactivity, ${ }^{[1-4]}$ special attention being paid to monoanionic aryl pincer-type. Aryl pincer ligands are widely used in organometallic chemistry for obtaining transition metal complexes. Their utility and importance in catalysis and material sciences was highlighted multiple times, being the subject of several reviews. ${ }^{[5-8]}$ Most of these reviews however, focus on pincer ligand stabilized transition metal complexes and their applications. ${ }^{[5-9]}$ Among the few data published on monoanionic aryl pincer ligand stabilized metallylenes, we would like to mention two book chapters dealing with group 13-15 elements. ${ }^{[10,11]}$ Therefore, the review of the latest results in the field is required.

In this work, monoanionic aryl pincer ligand (further referred to as pincer ligands) stabilized group 14 metallylenes will be reviewed.

The tridentate, monoanionic ligands, containing an aryl backbone, binding thorough a $\sigma$-bond to the metal or metalloid, and two flanking side arms with the donor groups, are known as pincer ligands. These are very attractive ligand platforms because of the possibility of fine-tuning the properties of the stabilized compounds by bringing modifications to the structure of the ligand. ${ }^{[6]}$ This property of the pincer-type ligand is well proven in the literature for transition metal complexes, hence the interest to apply them in the chemistry of low valent group 14 elements.

The first records of metallylenes stabilized by the intramolecular coordinations of a tridentate ligand appeared in the literature in 1981, when $\left[\mathrm{C}_{6} \mathrm{H}_{3}-2,6-\left(\mathrm{CH}_{2} \mathrm{NMe}_{2}\right)_{2}-\right] \mathrm{SnCl}, 2-\mathrm{CH}_{3} \mathrm{OC}_{6} \mathrm{H}_{4} \mathrm{SnCl}$, 2- $i-$ $\mathrm{C}_{3} \mathrm{H}_{7} \mathrm{OC}_{6} \mathrm{H}_{4} \mathrm{SnCl}$ and 2,4,6- $\left(\mathrm{CH}_{3} \mathrm{O}\right)_{3} \mathrm{C}_{6} \mathrm{H}_{2} \mathrm{SnCl}$ species were obatined. On the basis of Mossbauer and IR spectroscopy data, the authors concluded that divalent tin species are present, where the stabilization is achieved through the intramolecular coordination of the oxygen and nitrogen atoms. ${ }^{[12]}$ In 1989 van Koten and co-workers reported the first fully characterized tin(II) derivative stabilized by the tridentate, monoanionic 2,6-bis[(dimethylamino)methyl]phenyl $\left[\mathrm{C}_{6} \mathrm{H}_{3}-2,6-\left(\mathrm{CH}_{2} \mathrm{NMe}_{2}\right)_{2-}\right]$ group, ${ }^{[13]}$ opening the road for other classes of derivatives, including the pincer ligand stabilized metallylenes.

Even though in the chemistry of transition metal complexes the variety of pincer ligands employed is very large, in the case of the metallylenes there are only a few types of ligands that are used. Scheme 1 presents the pincer type ligands used for obtaining such species. 

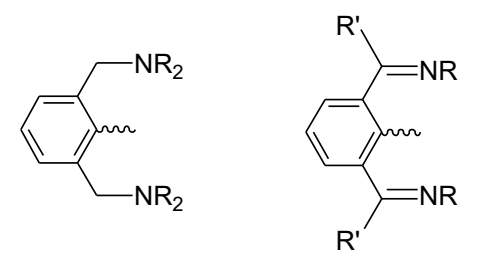

$\mathbf{L}^{\prime}$

$\mathrm{R}=\mathrm{Me}, \mathrm{Et}, i-\mathrm{Pr}$

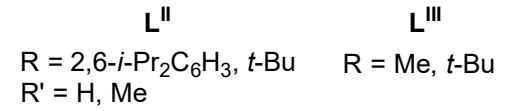

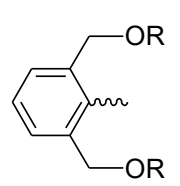

-Bu<smiles>[R6]P(=O)([O-])c1cc(C(C)(C)C)cc(P([R9])(=O)[O-])c1C</smiles>

LIV

$\mathrm{R}=\mathrm{Et}, i-\mathrm{Pr}$<smiles>[R]c1cc(S([O])(=O)=O)c(C)c(S([O])(=O)=O)c1</smiles>

$L^{v}$

$\mathrm{R}=\mathrm{H}, \mathrm{t}-\mathrm{Bu}$

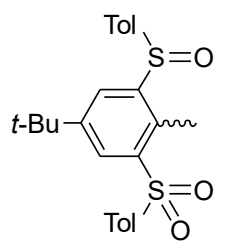

$\mathbf{L}^{\mathbf{V}}$

Scheme 1. Monoanionic aryl pincer ligands used for obtaining metallylenes

The synthesis of the metallylenes is usually realized by deprotonation of the ligand with a lithium derivative, in most cases $n$-BuLi or LDA, followed by reaction with dichlorometallylene moieties $\left(\mathrm{SnCl}_{2}, \mathrm{GeCl}_{2} \cdot\right.$ dioxane, $\left.\mathrm{PbCl}_{2}\right)$, as illustrated in Scheme 2 .

It is also important to mention that group 14 metallylenes are generally very unstable towards air and moisture, requiring the use of extremely dry and oxygen-free solvents and protective atmosphere.

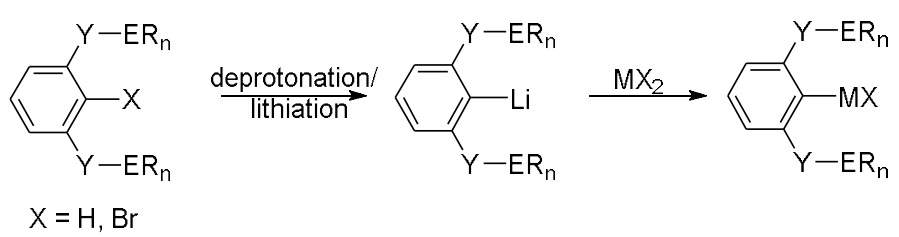

Scheme 2. General synthetic pathway of the pincer ligand stabilized metallylenes

As the chemistry of stannylenes displays numerous examples presented in the literature, significantly fewer data are available for germylenes and plumbylenes, and lack in the case of silylenes.

\section{Silylenes}

Even though there are several examples of tetravalent silicon species with pincer type ligands, ${ }^{[14-16]}$ up to date there are no examples of divalent silicon derivatives stabilized by these ligands. 


\section{Germylenes}

\subsection{Synthesis of germylenes}

Among the few examples of pincer stabilized halogermylenes presented in the literature, the majority are obtained with the use of $\mathrm{N}, \mathrm{C}, \mathrm{N}$-pincer ligands and there are only two examples for O,C,O-pincer supported chlorogermylenes.

The first examples for N,C,N-pincer ligand stabilized divalent germanium derivatives were presented by Bibal et al., with diethylaminomethyl groups as ortho substituents $\left(\mathrm{L}^{\mathrm{I}}\right)$, obtained through the reaction of 2,6-bis(dialkylaminomethyl)-phenyl bromide (alkyl $=\mathrm{Et}, i$-Pr) with $n$-BuLi then reaction with $\mathrm{GeCl}_{2}$.dioxane, as shown in Scheme 3. ${ }^{[17,18]}$ Similar methods were used to obtain the imino-based N,C,N-pincer ligand $\left(\mathrm{L}^{\mathrm{II}}\right)$ stabilized chlorogermylenes too, starting from N,N'-bis-(2,6diisopropylphenyl)-2-bromo-isophthalaldimine, ${ }^{[19]} \quad$ 2,6-bis[N-(2',6'-diisopropylphenyl)ketimino]phenyl-1-bromide ${ }^{[20]}$ or bis(N-tert-butyl)-2-bromoisophthalaldimine. ${ }^{[21]}$
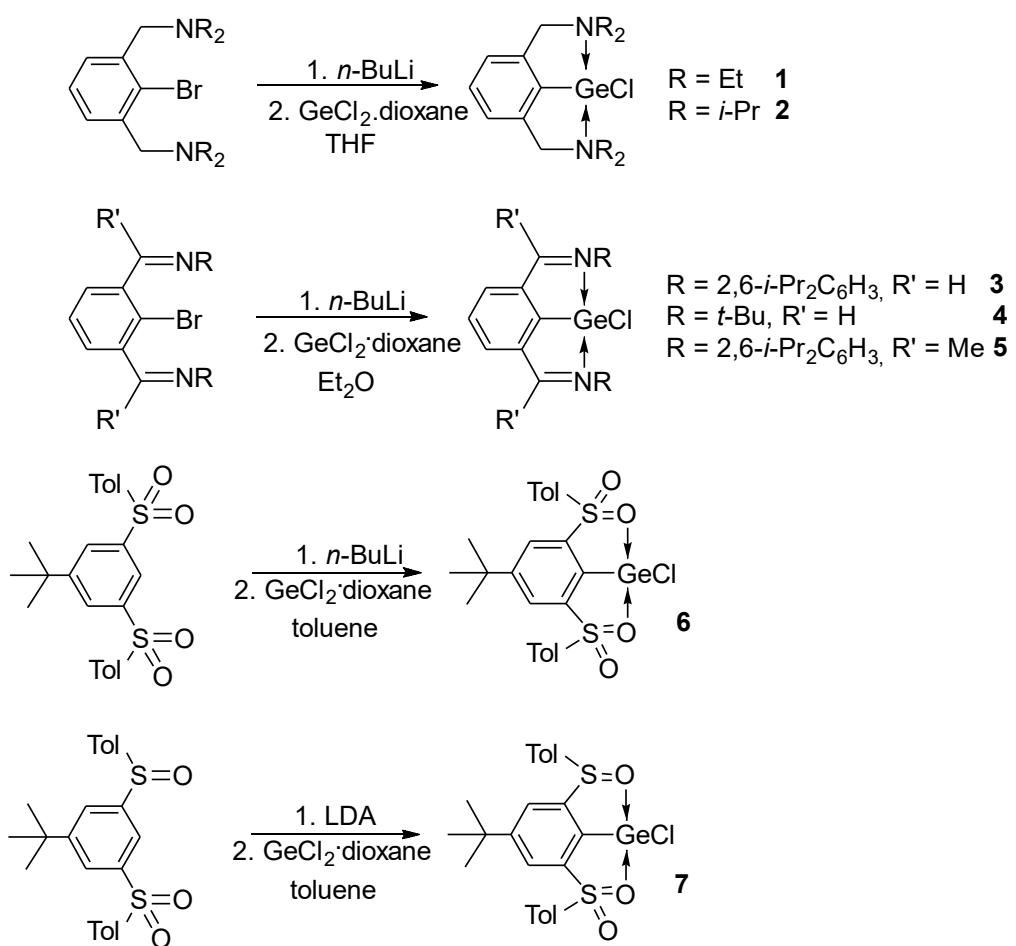

Scheme 3. Synthetic pathway for obtaining the N,C,N- and O,C,O-pincer stabilized chlorogermylenes

The only two fully characterized O,C,O-pincer ligand supported halogenogermylenes presented in the literature were synthesized by adding $n$-BuLi to 1,3-bis $\{(4$-methylphenyl)sulfonyl $\}$ 5-tert-butylbenzene $\left(\mathrm{L}^{\mathrm{V}}\right)^{[22]}$ or LDA to 1-(p-tolylsulfinyl)-3-tosyl-5-tert-butyl-benzene $\left(\mathrm{L}^{\mathrm{VI}}\right)^{[23]}$ in order 
to obtain the corresponding carbanions, which in reaction with $\mathrm{GeCl}_{2} \cdot \mathrm{dioxane}$ led to the desired germylenes 6 and 7, as shown in Scheme 3.

\subsection{Physical-chemical and structural characterization of germylenes}

The N,C,N- and O,C,O-pincer ligand stabilized germylenes 1-7 were characterized by the usual physical-chemical methods, both in solution and solid state. Some significant data are summarized in Table 1.

Table 1. Selection of physical-chemical data of germylenes

\begin{tabular}{|c|c|c|c|c|c|c|}
\hline & $\begin{array}{l}\text { Cipso-Ge bond } \\
\text { length }(\AA)\end{array}$ & $\begin{array}{l}\text { Ge-Cl bond length } \\
(\AA)\end{array}$ & $\begin{array}{l}\mathrm{E} \rightarrow \text { Ge bond length } \\
(\AA)\end{array}$ & $\begin{array}{l}\mathrm{C}_{\text {ipso-Ge-Cl }}-\mathrm{Cl} \text { bond } \\
\text { angle }\left({ }^{\circ}\right)\end{array}$ & $\begin{array}{l}{ }^{13} \mathrm{C} \text { NMR } \\
\delta \text { Cipso (ppm) }\end{array}$ & Ref. \\
\hline 1 & $1.941(11)$ & $2.309(4)$ & $\begin{array}{l}2.337(11) \\
2.570(10)\end{array}$ & $97.2(4)$ & $\begin{array}{l}157.48 \\
\text { (Tol-D } 8 \text { ) }\end{array}$ & {$[18]$} \\
\hline 2 & No RX data & & & & $\begin{array}{l}158.86 \\
\left(\mathrm{C}_{6} \mathrm{D}_{6}\right)\end{array}$ & {$[18]$} \\
\hline 3 & $2.028(3)$ & $2.3288(8)$ & $\begin{array}{l}2.247(3) \\
2.62(1)\end{array}$ & $100.61(8)$ & $\begin{array}{l}132.29 \\
\left(\mathrm{C}_{6} \mathrm{D}_{6}\right)\end{array}$ & [19] \\
\hline 4 & $2.0004(19)$ & $2.3477(5)$ & $\begin{array}{l}2.2981(17) \\
2.57(1)\end{array}$ & $93.95(5)$ & & {$[21]$} \\
\hline 5 & No RX data & & & & $\begin{array}{l}171.19\left(\mathbf{C}_{\text {ipso }}\right) \\
\left(\mathrm{THF}-\mathrm{D}_{8}\right)\end{array}$ & [20] \\
\hline 6 & $2.030(3)$ & $2.287(2)$ & $2.359(2)$ & $93.78(5)$ & $\begin{array}{l}159.9 \\
\left(\mathrm{CDCl}_{3}\right)\end{array}$ & {$[22]$} \\
\hline 7 & $2.027(2)$ & $2.308(1)$ & $2.069(2)$ & $95.45(5)$ & $\begin{array}{l}155.3 \\
\left(\mathrm{CDCl}_{3}\right)\end{array}$ & {$[23]$} \\
\hline
\end{tabular}

The ${ }^{1} \mathrm{H}$ and ${ }^{13} \mathrm{C}$ NMR analysis of germylenes 1-7 showed the characteristic signals for the ligand backbone and the donor side-chains. The ${ }^{1} \mathrm{H}$ NMR showed that the chelating side-chains were equivalent in the case of germylenes 1-2 with the exchange of the coordination sites. ${ }^{[18]}$ In the case of germylene 5 the ${ }^{1} \mathrm{H}$ NMR analysis indicated nonequivalent $\mathrm{H}$ atoms on the ortho side-chains. ${ }^{[19]}$ In the ${ }^{13} \mathrm{C}$ NMR spectra the signal for the $\mathbf{C}_{i p s o}$ carbon atom in each case appears deshielded compared to the one in the corresponding ligands. This chemical shift is characteristic for the formation of the germylenes. ${ }^{[18,19]}$

In case of the germylenes stabilized with O,C,O-pincer type ligands, for both derivatives $\mathbf{6}$ and 7, the specific signals in the ${ }^{1} \mathrm{H}$ and ${ }^{13} \mathrm{C}$ NMR spectra showed the formations of the desired compounds. The disappearance of the characteristic triplet signal for the ipso proton in the ${ }^{1} \mathrm{H}$ NMR spectrum (8.23 ppm in bis-sulfoxide $\mathrm{L}^{\mathrm{V}}$ and $7.87 \mathrm{ppm}$ in sulfone-sulfoxide $\mathrm{L}^{\mathrm{VI}}$ ), highlights the formation of the targeted germylenes. Furthermore, in ${ }^{13} \mathrm{C}$ NMR spectra the upfield-shifted signals of the $\mathbf{C}_{i p s o}$ of the central aromatic ring were observed. In the case of germylene $\mathbf{6}$ stabilized with bissulfone ligand the signal shift to $154.9 \mathrm{ppm}$ in bis-sulfone from 159.9 in germylene while in the case 
of germylene 7 stabilized with sulfone-sulfoxide O,C,O-pincer type ligand the signal for $\mathbf{C}_{i p s o}$ shift from 126.5 to 162.5 ppm. $^{[22,23]}$

The X-ray analyses realized on the germylenes, revealed that the ligands are bonded tridentately to the germanium atoms, through a $\mathrm{C}-\mathrm{Ge} \sigma$ chemical bond and by two intramolecular $\mathrm{N} \rightarrow \mathrm{Ge}$ or $\mathrm{O} \rightarrow \mathrm{Ge}$ coordinative bonds. In the case of the N,C,N-pincer ligand supported germylenes, it was observed, that one of the $\mathrm{N} \rightarrow \mathrm{Ge}$ distances is significantly larger than the other one, showing that one of the interactions is usually stronger. Even though the second $\mathrm{N} \rightarrow \mathrm{Ge}$ distance is longer, the values are shorter than the sum of the van der Waals radii ( $3.70 \AA),{ }^{[24,25]}$ thus the authors consider them rather weak N-Ge coordination bond (see Table 1). ${ }^{[18-21]}$ Taking into account that both nitrogengermanium distances in each case are considered interactions, in the schemes presented in this review they will be marked as coordinations. In the case of the bis-sulfone O,C,O-pincer supported germylene (Scheme 3) the $\mathrm{O} \rightarrow$ Ge distances $(2.359(2) \AA)^{[22]}$ are equal in the case of the bis-sulfone type ligand while in the case of sulfone-sulfoxide pincer ligand, the distance $\mathrm{O}_{\text {sulfoxide }} \rightarrow \mathrm{Ge}(2.069$ (2) $\AA)$ is significantly shorter that the distance $\mathrm{O}_{\text {sulfone }} \rightarrow \mathrm{Ge}$ one $(2.689(2) \AA) .{ }^{[23]}$ The $\mathrm{Ge}-\mathrm{Cl}$ bond is situated in an almost orthogonal position to the plane of the aryl ring, with the $\mathbf{C}_{i p s o}-\mathrm{Ge}-\mathrm{Cl}$ angle varying between $93.78(5)$ and $100.61(8)^{\circ}$. The geometrical parameters around the germanium atom suggest in each case a low hybridization degree, the coordination of the $\mathrm{N}$ or the $\mathrm{O}$ atom involving probably the vacant p-orbitals of the Ge atom and the lone pair being situated in an orbital with $s$ character.

Furthermore, the short Ge-C bond length in germylene 1 (1.941(11) $\AA$ ) compared to other chlorogermylenes described in the literature (1.989(5)-2.402(3) $\AA),{ }^{[18]}$ suggests the presence of a germanium - ipso-carbon back bonding. This can be the result of the electronic effects of the $\mathrm{N} \rightarrow \mathrm{Ge}$ donation and the increased electrophilic character of the ipso-carbon through the withdrawing inductive effect of the ortho $\mathrm{CH}_{2} \mathrm{NEt}_{2}$ moieties. Ge atoms adopt a distorted trigonal-pyramidal geometry.

The intramolecular coordination of the $\mathrm{N}$ or $\mathrm{O}$ atom from the functional groups of the pincer ligand toward the $\mathrm{Ge}(\mathrm{II})$, weakens drastically the $\mathrm{Ge}-\mathrm{Cl}$ bond and the distances between the two atoms increase. Accordingly, such derivatives are suitable for easy nucleophilic substitutions at the divalent metal centre to access different compounds.

\subsection{Reactivity of chlorogermylenes}

The reactivity of the halogermylenes was tested towards several different reagents, with the aim of obtaining and stabilizing a series of new species. Due to its particular geometry, given by the chlorine atom and the lone pair of electron of the germanium(II) species, both substitution and 
coordination reactions are possible. Yet, the substitution of the chlorine atom is the most common, representing an easy method of obtaining new, functionalized germylenes.

The substitution of the chlorine atom in the $\mathrm{L}^{\mathrm{I}} \mathrm{GeCl}\left(\mathrm{L}^{\mathrm{I}}=2,6\right.$-bis-((diethylamino) methyl)phenyl, $\mathrm{C}_{6} \mathrm{H}_{3}\left(\mathrm{CH}_{2} \mathrm{NMe}_{2}\right)_{2}$-2,6) germylene 1 proves its utility in obtaining functionalized germylenes. Reaction with LiNR ${ }_{2}\left(\mathrm{R}^{\prime}=\mathrm{SiMe}_{3}, i\right.$-Pr) led to aminogermylenes $\mathrm{L}^{\mathrm{I}} \mathrm{GeNR}{ }_{2} \mathbf{8}$ and 9. ${ }^{[26]} \mathrm{In}$ these species, the high reactivity of the Ge-N bond led to new compounds, L ${ }^{\mathrm{I}} \mathrm{GeOMes} \mathbf{1 0}$ was obtained by substitution of the $\mathrm{N}(i-\mathrm{Pr})_{2}$ group. A transition metal complex of the $\mathrm{L}^{\mathrm{I}} \mathrm{GeNR}{ }_{2}$ was synthesized with $\mathrm{W}(\mathrm{CO})_{5}$, then hydrolysed to obtain stable hydroxygermylene 11. In complex $\mathbf{1 1}$ an enhanced germanium-nitrogen interaction can be observed between the diethylamino groups and the central atom, owing to the presence of the germanium-tungsten coordination, the Ge- $\mathrm{N}$ distance of 2.113(3) $\AA$ being much shorter than in the starting germylene 8 (2.390(3) $\AA$ ). ${ }^{[26]}$ Through the hydrolysis of the aminogermylene $\mathrm{L}^{\mathrm{I}} \mathrm{GeNR}$, a siloxygermylene-tungsten complex $\mathbf{1 2}$ was also achieved, its formation being explained through the monosilylated aminogermylene intermediate, as shown in Scheme 4. ${ }^{[26]}$

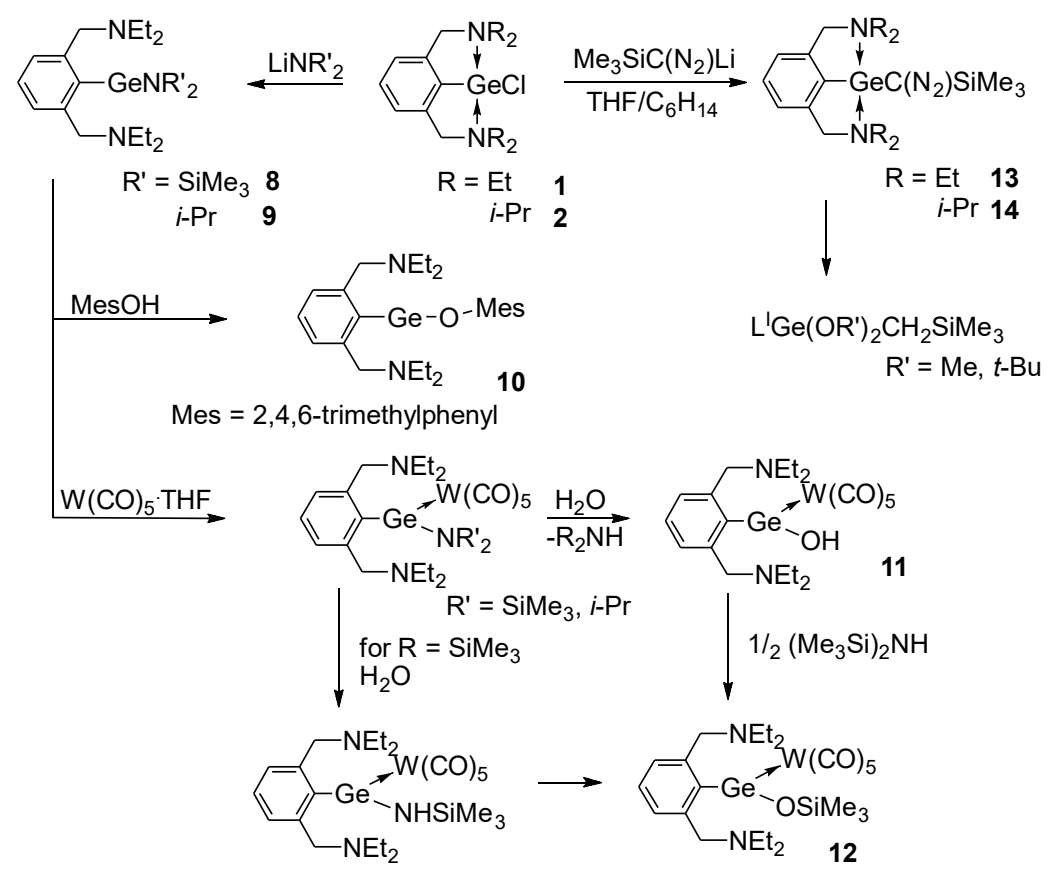

Scheme 4. Reactivity of the amine N,C,N-pincer chlorogermylenes

In the case of the tungsten complex 11, both NMR and X-Ray analysis emphasized the absence of the back bonding seen in the germylene 1 due to the complexation of the Ge, evidenced by the lengthening of the $\mathbf{C}_{i p s o}-\mathrm{Ge}$ bond from 1.941(11) in germylene $\mathbf{1}$ to $1.975(3) \AA$ in complex 11, ${ }^{[18,26]}$ and the shift of the signal of the $\mathbf{C}_{i p s o}$ carbon atom in the ${ }^{13} \mathrm{C}$ NMR spectrum, becoming more shielded in derivative $\mathbf{1 1}$ (153.44 ppm) than in germylenes $\mathbf{1}$ and $\mathbf{2}$ (157.48 and $158.86 \mathrm{ppm}$ ) (see Tables 1 and 2). ${ }^{[18,26]}$ 
Table 2. Selection of physical-chemical data of functionalized germylenes

\begin{tabular}{|c|c|c|c|c|c|c|c|}
\hline & $\begin{array}{l}\text { Cipso-Ge bond }- \text { bon }(\AA) \\
\text { length }\end{array}$ & $\begin{array}{l}\text { Ge-R bond } \\
\text { length }(\AA)\end{array}$ & $\begin{array}{l}\text { Ge-M bond } \\
\text { length }(\AA ̊)\end{array}$ & $\begin{array}{l}\mathrm{E} \rightarrow \text { Ge bond } \\
\text { length }(\AA)\end{array}$ & $\begin{array}{l}\mathrm{C}_{i p s o}-\mathrm{Ge}-\mathrm{R} \\
\text { bond angle } \\
\left({ }^{\circ}\right)\end{array}$ & $\begin{array}{l}{ }^{13} \text { C NMR } \delta \\
\text { Cipso }(p p m)\end{array}$ & Ref \\
\hline 8 & $2.022(5)$ & $\begin{array}{l}\mathrm{Ge}-\mathrm{N} \\
1.956(0)\end{array}$ & & $\begin{array}{l}2.390(3) \\
2.699(1) \\
\end{array}$ & & $158.99\left(\mathrm{C}_{6} \mathrm{D}_{6}\right)$ & {$[26]$} \\
\hline 9 & No RX data & & & & & $158.32\left(\mathrm{C}_{6} \mathrm{D}_{6}\right)$ & {$[26]$} \\
\hline 10 & No RX data & & & & & $158.78\left(\mathrm{C}_{6} \mathrm{D}_{6}\right)$ & {$[26]$} \\
\hline 11 & $1.975(3)$ & $\begin{array}{l}\mathrm{Ge}-\mathrm{O} \\
1.787(2)\end{array}$ & $\begin{array}{l}\text { Ge-W } \\
2.595(0)\end{array}$ & $2.113(3)$ & & $\begin{array}{l}153.44 \\
\left(\mathrm{C}_{6} \mathrm{D}_{6}\right)\end{array}$ & {$[26]$} \\
\hline 12 & No RX data & & & & & $\begin{array}{l}148.75 \\
\left(\mathrm{C}_{6} \mathrm{D}_{6}\right)\end{array}$ & {$[26]$} \\
\hline 13 & No Rx data & & & & & $\begin{array}{l}156.85 \\
\left(\text { Tol-D }_{8}\right)\end{array}$ & {$[17]$} \\
\hline 14 & $2.006(5)$ & $\begin{array}{l}\mathrm{Ge}-\mathrm{C} \\
2.02(1)\end{array}$ & & $\begin{array}{l}2.35(9) \\
3.05(3)\end{array}$ & $\begin{array}{l}\text { C }_{\text {ipso-Ge-C }}-\mathrm{C} \\
96.84(7)\end{array}$ & $\begin{array}{l}158.39 \\
\left(\text { Tol-D }_{8}\right)\end{array}$ & {$[17]$} \\
\hline 15 & $\begin{array}{l}1.967(3) \\
1.990(3)\end{array}$ & $\begin{array}{l}\text { Ge-Ge } \\
2.5059(5)\end{array}$ & & $\begin{array}{l}1.986(3) \\
2.036(3)\end{array}$ & $\begin{array}{l}89.10(9) \\
116.11(10)\end{array}$ & & [19] \\
\hline 16 & $1.909(4)$ & & & $1.925(3)$ & & & [19] \\
\hline 17 & $1.957(4)$ & & $2.6068(15)$ & $1.905(3)$ & & & {$[19]$} \\
\hline 18 & $1.947(4)$ & & $\begin{array}{l}\text { Ge-Ca } \\
3.2292(10)\end{array}$ & $1.911(3)$ & & Not assigned* & [19] \\
\hline 19 & $2.000(4)$ & $\begin{array}{l}\mathrm{Ge}-\mathrm{N} \\
1.971(3) \\
\end{array}$ & & $\begin{array}{l}2.370(3) \\
2.465(3) \\
\end{array}$ & & & [27] \\
\hline 20 & $2.010(12)$ & $\begin{array}{l}\mathrm{Ge}-\mathrm{O} \\
1.906(7)\end{array}$ & & $\begin{array}{l}2.325(10) \\
2.493(11) \\
\end{array}$ & & & [27] \\
\hline 21 & $\begin{array}{l}1.991(3) \\
1.995(3)\end{array}$ & & & $\begin{array}{l}2.081(2)- \\
2.127(2)\end{array}$ & & & [21] \\
\hline 22 & $1.946(4)$ & & $\begin{array}{l}\mathrm{Li}-\mathrm{Ge} \\
2.680(7)\end{array}$ & $1.939(3)$ & & & [21] \\
\hline 23 & $1.9483(18)$ & $\begin{array}{l}\text { Calculated } \\
\text { Ge-H 1.583- } \\
1.588 \\
\end{array}$ & & $\begin{array}{l}2.2722(15) \\
2.2746(15)\end{array}$ & & $\begin{array}{l}176.48\left(\mathbf{C}_{\text {ipso }}\right) \\
\left(\mathrm{THF}_{8} \mathrm{D}_{8}\right)\end{array}$ & [20] \\
\hline 24 & $1.958(4)$ & $\begin{array}{l}\mathrm{Ge}-\mathrm{Cl} \\
2.108(1)\end{array}$ & & $\begin{array}{l}2.568(3) \\
2.841(3)\end{array}$ & $118.06(11)$ & Not seen** & {$[28]$} \\
\hline 25 & $1.968(10)$ & $\begin{array}{l}\mathrm{Ge}-\mathrm{Cl} \\
2.138(4) \\
\end{array}$ & $\begin{array}{l}\mathrm{Ge}-\mathrm{Fe} \\
2.296(2)\end{array}$ & $\begin{array}{l}2.257(7) \\
2.329(6) \\
\end{array}$ & $105.9(3)$ & No data*** & {$[22]$} \\
\hline 26 & $1.983(4)$ & $\begin{array}{l}\mathrm{Ge}-\mathrm{Cl} \\
2.191(1)\end{array}$ & $\begin{array}{l}\text { Ge-W } \\
2.550(8)\end{array}$ & $\begin{array}{l}2.287(3) \\
2.318(3)\end{array}$ & 105.79(13) & $\begin{array}{l}147.9 \\
\left(\mathrm{CDCl}_{3}\right)\end{array}$ & {$[22]$} \\
\hline
\end{tabular}

The $\mathrm{L}^{\mathrm{I}} \mathrm{GeCl}$ chlorogermylene was also used to bring evidence for the first germyne, containing a germanium-carbon triple bond. ${ }^{[17]}$ Reaction of chlorogermylenes $\mathbf{1}$ and $\mathbf{2}$ with $\mathrm{Li}\left(\mathrm{N}_{2}\right) \mathrm{CSiMe}_{3}$ (lithiotrimethylsilyldiazomethane) led to diazogermenes 13 and 14. ${ }^{[17]}$ The X-ray analysis of compound $\mathbf{1 4}$ showed that only one N-Ge intramolecular coordination is still present

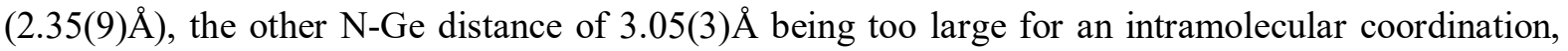
thus was considered only a weak interaction. After irradiation of compound $\mathbf{1 4}$ in the presence of a trapping agent, $\mathrm{L}^{\mathrm{I}} \mathrm{Ge}\left(\mathrm{OR}^{\prime}\right)_{2} \mathrm{CH}_{2} \mathrm{SiMe}_{3}\left(\mathrm{R}^{\prime}=\mathrm{Me}, t\right.$-Bu) was evidenced, its formation explained through a germyne intermediate. ${ }^{[17]}$ 


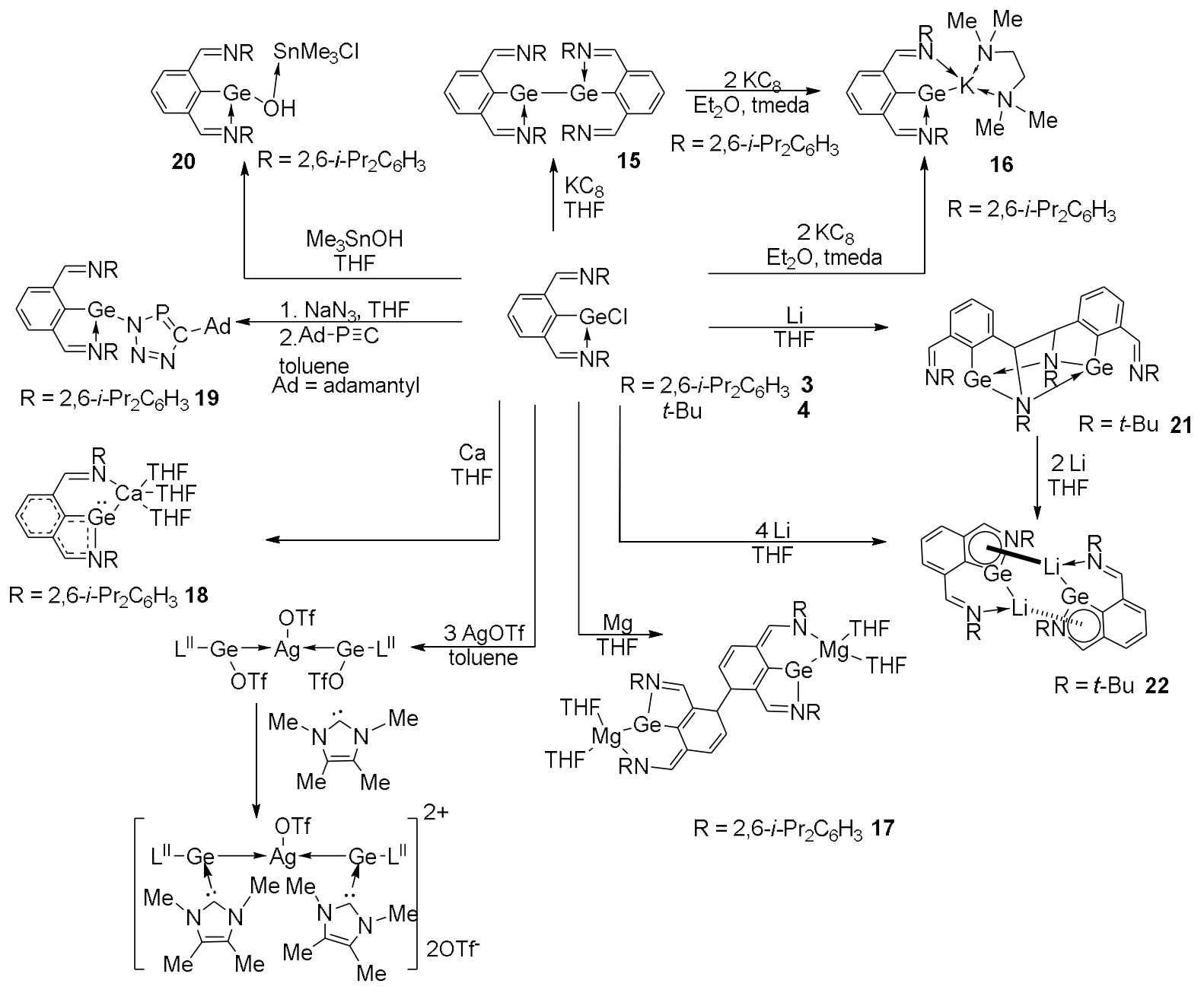

Scheme 5. Reactivity of imino-N,C,N-pincer based germylenes

In the case of $\mathrm{L}^{\mathrm{II}} \mathrm{GeCl} 3\left(\mathrm{~L}^{\mathrm{II}}=2,6-(\mathrm{CH}=\mathrm{NR})_{2} \mathrm{C}_{6} \mathrm{H}_{3}, \mathrm{R}=2,6-i-\mathrm{Pr}_{2} \mathrm{C}_{6} \mathrm{H}_{3}\right)$, where the N-donor side-chain is an imino group, the reactivity study of the chlorogermylene was focused on obtaining germylidenide anions and radicals through reduction with different reactives (Scheme 5). ${ }^{[19,29]}$ Reaction of chlorogermylene 3 with $\mathrm{KC}_{8}$ in THF led to digermylene 15, containing a Ge-Ge single bond (2.5059(5) $\AA$ ) (Scheme ). The formation of this species is presumed to involve a Ge(I) radical intermediate. ${ }^{[19]}$ The ${ }^{1} \mathrm{H}$ NMR analysis showed non-equivalent imino groups that present fluxional behaviour in solution. The X-ray solid state molecular structure revealed that the Ge atoms are in a distorted trigonal-pyramidal geometry as in the starting germylenes suggesting that the lone pair of electrons are still situated on the germanium atoms. ${ }^{[19]}$ The $\mathbf{C}_{i p s o}-\mathrm{Ge}$ and $\mathrm{N}-\mathrm{Ge}$ bonds in the digermylene are shorter than in the parent germylene. The digermene $\mathbf{1 5}$ reacted with $\mathrm{KC}_{8}$ in the presence of tetramethylethylenediamine (TMEDA) to form a germylidene anion (16) containing $\mathrm{L}^{\mathrm{II}} \mathrm{GeK} \cdot \mathrm{TMEDA}$ complex, where the stabilization of the species was suggested to be realized through electron delocalization on the GeCCCN heterocycles. This compound was obtained also by adding excess of $\mathrm{KC}_{8}$ to chlorogermylene 3 . The molecular structure showed that the $\mathrm{K}$ atom is $\eta^{1}$-coordinated to the Ge atom. ${ }^{[19]}$ 
Chlorogermylene 3 in the presence of $\mathrm{Ca}$ in THF formed the germylidendiide dianion radical 18 while with $\mathrm{Mg}$ a germylidenide complex 17 was obtained (Scheme 5). ${ }^{[29]}$ The authors showed that the formation of the calcium derivative is realized through a germanium(I) radical reduced by the calcium, thus the same compound could be obtained starting from the digermylene $\mathbf{1 5}$. Compound $\mathbf{1 8}$ contains a germanium atom with two lone pairs of electrons and an unpaired electron delocalized on the heterocycle. The $\mathrm{Ca}$ atom is $\eta^{5}$-coordinated to the heterocycle comprising the $\mathbf{C}_{i p s o}$-Ge bond and an imine side-chain. The geometrical parameters obtained from the solid state molecular structure suggest that the Ge-Ca bond is ionic, with the distance of 3.2292(10) $\AA$, longer than the sum of the covalent radii ( $2.95 \AA$ ). In the reaction of $\mathbf{3}$ with magnesium, dimerization and dearomatization of the ligand took place, forming a germylidenide 17 (Scheme 5), the authors proposing that the germylidendiide dianion radical is unstable, leading to the obtained derivative. The molecular structure shows that the $\mathrm{Mg}$ atom is coordinated with the Ge atom and a $\mathrm{N}$ atom of the imine sidechain, with the Ge-Mg bond of 2.6068(15) $\AA$ and the Mg-N one of 2.001(3) $\AA$. The geometrical parameters suggest that an electron delocalization on the $\mathrm{GeC}_{i p s o} \mathrm{CCN}$ heterocycle is stabilizing the lone pair of electrons of the germanium atom. ${ }^{[29]}$

Chlorogermylene 3 reacted with $\mathrm{Me}_{3} \mathrm{SnOH}$ to form germylene hydroxide 20, that cocrystallyzes with $\mathrm{Me}_{3} \mathrm{SnCl}$. The solid state molecular structure shows, that the Ge-N distances are of $2.325(10) \AA$ and 2.493(11) $\AA$, displaying thus one strong and one weak interaction. ${ }^{[27]}$ With $\mathrm{NaN}_{3}$ chlorogermylene 3 gave germanium(II) azide $\mathrm{L}^{\mathrm{II}} \mathrm{GeN}_{3}$, identified by NMR and IR spectroscopy. The azide reacted with 1-adamantylphosphaalkyne through a 1,3-dipolar cycloaddition, giving 19, as shown in Scheme 5, characterized by NMR spectroscopy and X-ray crystallography. ${ }^{[27]}$

When the substituents on the nitrogen atoms of the ortho-imino moieties of the $\mathrm{L}^{\mathrm{II}} 2,6$ bis(imino)phenyl ligand are changed from 2,6-diisopropylphenyl to tert-butyl groups, the formation of the germylidenide anion was described in the reaction of chlorogermylene 4 with lithium. With addition of lithium to $\mathbf{4}$, a bis-germylene was formed and for the reaction mechanism it was suggested by the authors, that the imine moiety of the ligand's ortho side-chain is reduced to an imine radical anion, then through a $\mathrm{C}-\mathrm{C}$ coupling reaction the bis-germylene $\mathbf{2 1}$ is formed (Scheme 5 ). ${ }^{[21]} \mathrm{With} \mathrm{Li}$ added to the bis-germylene $\mathbf{2 1}$ or in excess to germylene $\mathbf{4}$, the formation of a lithium germylidenide 22 was observed, as shown in Scheme 5. It was proposed, that the divalent germanium centres undergo reduction, then through the homolytic cleavage of the $\mathrm{C}-\mathrm{C}$ bond, compound $\mathbf{2 2}$ is observed. ${ }^{[21]}$ The solid state molecular structures of compounds $\mathbf{2 1}$ and $\mathbf{2 2}$ were determined by X-ray diffraction. For the bis-germylene, the Ge-N bonds display values in-between 2.081(2) and 2.127(2) $\AA$, being thus regarded as coordinative bonds and suggesting two resonance structures. Within germylene 22, both $\mathrm{N}$ and Ge atoms coordinate to the Li atoms in a $\eta^{1}$ fashion, whereas the $\mathrm{GeC}_{\mathrm{ipso}} \mathrm{CCN}$ heterocycles display a $\eta^{5}$ coordination, as depicted in Scheme 5. ${ }^{[21]}$

Chlorogermylene 4 in reaction with AgOTf and 1,3-dimethyl-4,5-dimethylimidazol-2-ylidene (2 equivalents) led to the first bis(germyliumylidene)silver(I) complex. ${ }^{[30]}$ This compound, extremely air- 
and moisture sensitive, was completely characterized, including the solid structure determined by Xray diffraction.

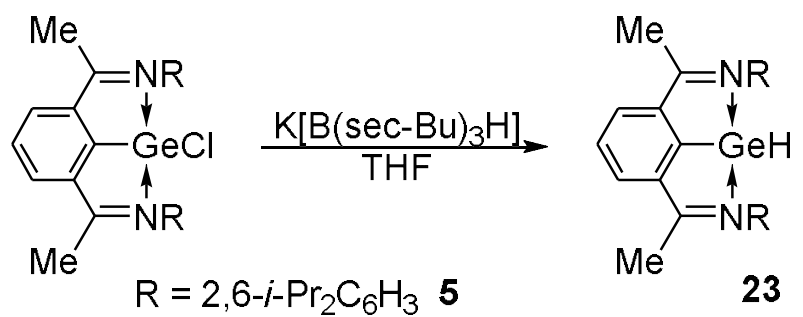

Scheme 6. Reactivity of an imino-N,C,N-pincer ligand based germylene

Chlorogermylene $\mathbf{5}$, with the slightly modified imino-based N,C,N-type pincer ligand $\left(\mathrm{L}^{\mathrm{II}}=\right.$ 2,6- $\left.(\mathrm{CMe}=\mathrm{NR})_{2} \mathrm{C}_{6} \mathrm{H}_{3}, \mathrm{R}=2,6-i-\mathrm{Pr}_{2} \mathrm{C}_{6} \mathrm{H}_{3}\right)$ in reaction with $\mathrm{K}\left[\mathrm{B}(\mathrm{sec}-\mathrm{Bu})_{3} \mathrm{H}\right]$ (Scheme 6) formed $\mathrm{Ge}(\mathrm{II})$ hydride 23. The solid state structure shows Ge-N lengths of 2.2722(15) $\AA$ and of 2.2746(15) $\AA$, these coordinate bond stabilizing the compound by electron donation into the empty $p$ orbital of the germanium atom. ${ }^{[20]}$

The reactivity of bis-sulfone O,C,O-pincer supported germylene $\mathbf{6}$ was studied in cycloaddition and coordination reactions (Scheme 7). ${ }^{[22,28]}$

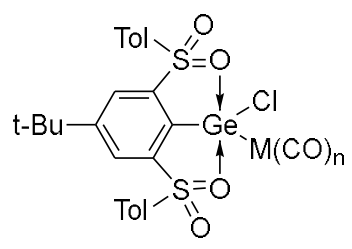

$M=F e, n=4 \quad 25$ $M=W, n=5 \quad 26$

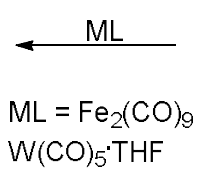
$\mathrm{W}(\mathrm{CO})_{5} \cdot \mathrm{THF}$

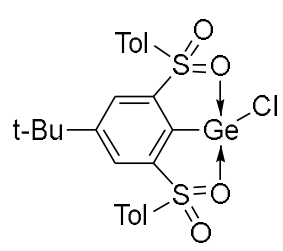

6<smiles>CC(C)(C)C1=CC([13C](F)(F)C(C)(C)C)=CC(=O)C1=O</smiles><smiles>CC(C)(C)c1cc(C(C)(C)C)c(OC(Cl)(Cl)c2c(S(=O)(=O)O)cc(C(C)(C)C)cc2S(=O)(=O)O)c(C(C)(C)C)c1</smiles>

Scheme 7. Reactivity of the bis-sulfone O,C,O-chlorogermylene

In the presence of ortho-benzoquinone, germylene $\mathbf{6}$ formed cycloadduct $\mathbf{2 4}$, with a tetravalent germanium atom. The $\mathrm{O}-\mathrm{Ge}$ distances of 2.568(3) and 2.841(3) are too large to consider them coordinative interactions. ${ }^{[28]}$ Transition metal complexes of germylene 6 were obtained with iron and tungsten carbonyls, as shown in Scheme 7. Complexes 25 and 26 were characterized by NMR spectroscopy and X-ray diffraction, the solid state structures showing strong O-Ge coordinations in both cases (See Table 2). ${ }^{[22]}$

The reactivity of germylene 7 stabilized with sulfone-sulfoxide O,C,O-pincer ligand towards iron and tungsten complexes was also investigated, ${ }^{[23]}$ but the reaction with pentacarbonyl tungsten or diironnonacarbonyl could not be proven so far. 


\section{Stannylenes}

\subsection{Synthesis of stannylenes}

The literature reports several examples of stannylenes stabilized by different type of monoanionic aryl pincer ligands which will be briefly presented. The synthesis of the divalent tin derivatives is realized in a similar manner to the germylenes; $n$-BuLi or LDA is added at low temperature to the ligand in order to obtain the corresponding lithium derivative, followed by a transmetallation with $\mathrm{SnCl}_{2}$.

The first stannylene stabilized with a monoanionic aryl pincer ligand reported in the literature, contained a $\mathrm{L}^{\mathrm{I}} \mathrm{SnCl}$ ligand type $\left(\mathrm{L}^{\mathrm{I}}=2,6-\left(\mathrm{R}_{2} \mathrm{NCH}_{2}\right)_{2} \mathrm{C}_{6} \mathrm{H}_{3}, \mathrm{R}=\mathrm{Me}\right)$, with amino groups as ortho substituents. This compound was first mentioned in 1981 by Zuckerman, ${ }^{[12]}$ then described and characterized by van Koten in 1989. ${ }^{[13]}$
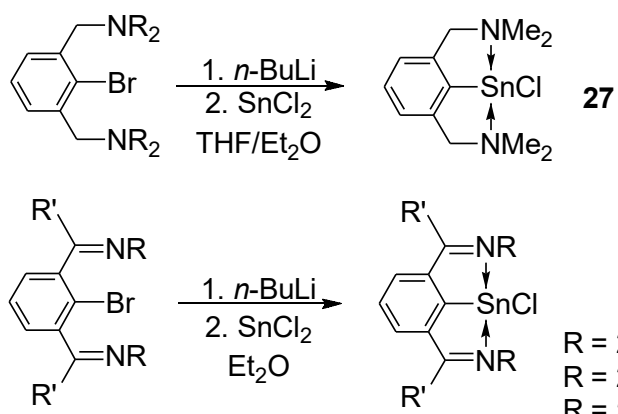<smiles>[R]C1=CC=CC2=C([R])C([R])=[R17](Cl)[Si]12Cl</smiles>

$\mathrm{R}=2,6-i-\mathrm{Pr}_{2} \mathrm{C}_{6} \mathrm{H}_{3}, \mathrm{R}^{\prime}=\mathrm{Me} 28$

$\begin{array}{ll}\mathrm{R}=2,6-\mathrm{Me}_{2}-\mathrm{C}_{6} \mathrm{H}_{3}, \mathrm{R}^{\prime}=\mathrm{H} & \mathbf{2 9} \\ \mathrm{R}=t-\mathrm{Bu}, \mathrm{R}^{\prime}=\mathrm{H} & \mathbf{3 0}\end{array}$
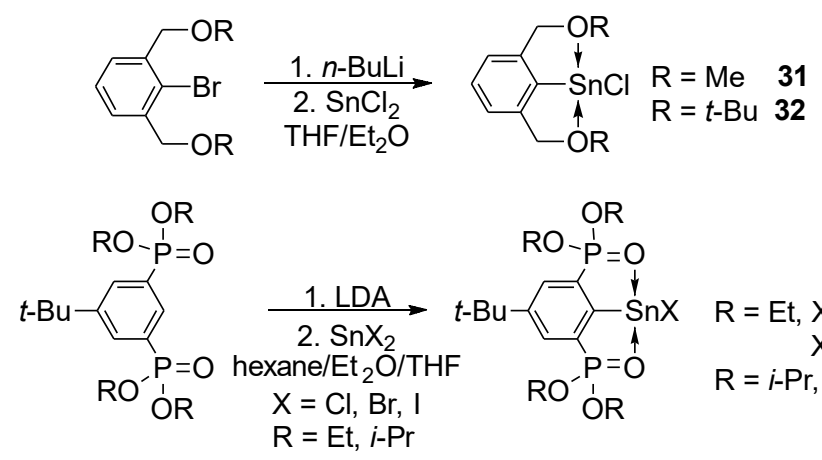

$$
\begin{array}{rl}
\mathrm{R}=\mathrm{Et}, \mathrm{X}=\mathrm{Cl} & 33 \\
\mathrm{X}=\mathrm{Br} & 34 \\
\mathrm{R}=i-\mathrm{Pr}, \mathrm{X}=\mathrm{Cl} & \mathbf{3 5} \\
\mathrm{X}=\mathrm{Br} & \mathbf{3 6} \\
\mathrm{X}=\mathrm{I} & \mathbf{3 7}
\end{array}
$$<smiles></smiles>

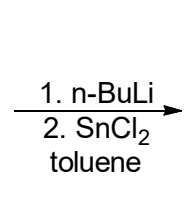<smiles>[R]c1ccc2c(c1)S(=O)(=O)O[Sn]2Cl</smiles><smiles>[R][R]([R])=[As][As]</smiles>

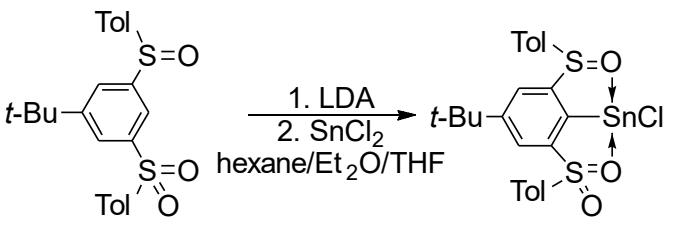

Scheme 8. Synthesis of stannylenes 
It was obtained by adding, in the first step, $n$-BuLi to 2,6-bis(methylaminomethyl)-phenyl bromide; the lithium intermediate then reacted with $\mathrm{SnCl}_{2}$ in the second step to obtain the desired stannylene. ${ }^{[13]}$ For the synthesis of the other stannylenes similar methods were employed, as shown in Scheme 8 .

\subsection{Characterization of stannylenes}

The divalent tin derivatives were characterized by the usual physical-chemical methods in solution and in solid state: NMR spectroscopy, mass analysis, elemental analysis, IR and Mossbauer spectroscopy and single crystal X-ray diffraction. The most important geometrical parameters (bond lengths and angles) determined by X-ray diffraction, as well as the characteristic chemical shift resulting from NMR analysis, are summarized in Table 3.

Table 3. Selected geometrical and NMR parameters of stannylenes

\begin{tabular}{|c|c|c|c|c|c|c|c|}
\hline & $\begin{array}{c}\text { Cipso-Sn bond }_{\text {ingth }(\AA)} \\
\text { lengt }\end{array}$ & $\begin{array}{l}\text { Sn-X bond } \\
\text { length }(\AA)\end{array}$ & $\begin{array}{c}\mathbf{E} \rightarrow \text { Sn bond } \\
\text { length }(\AA)\end{array}$ & $\begin{array}{c}C_{i p s o}-\mathrm{Sn}-\mathrm{X} \text { bond } \\
\text { angle }\left({ }^{\circ}\right)\end{array}$ & $\begin{array}{c}{ }^{13} \text { C NMR } \\
\delta C_{\text {ipso }}(\mathrm{ppm}) \\
J(\mathrm{~Hz}) \\
\end{array}$ & ${ }^{119}$ Sn NMR (ppm) & Ref. \\
\hline 27 & $2.158(8)$ & $\begin{array}{c}\mathrm{X}=\mathrm{Cl} \\
2.488(3)\end{array}$ & $\begin{array}{c}E=N \\
2.525(8) \\
2.602(8)\end{array}$ & $95.0(3)$ & $\begin{array}{c}170.7 \\
{ }^{1} \mathrm{~J}_{\mathrm{C}-\mathrm{Sn}}=350 \mathrm{~Hz} \\
\left(\mathrm{Tol}-\mathrm{D}_{8}\right)\end{array}$ & $\begin{array}{c}155.6 \\
(\text { Tol-D8) }\end{array}$ & {$[12,13]$} \\
\hline 28 & No RX data & & & & Not given & $\begin{array}{c}-20 \\
\left(\mathrm{C}_{6} \mathrm{D}_{6}\right)\end{array}$ & [31] \\
\hline 29 & No RX data & & & & Not given & $\begin{array}{c}25.5 \\
\left(\mathrm{C}_{6} \mathrm{D}_{6}\right)\end{array}$ & [32] \\
\hline 30 & $2.177(2)$ & $\begin{array}{c}\mathrm{X}=\mathrm{Cl} \\
2.5625(5)\end{array}$ & $\begin{array}{c}\mathrm{E}=\mathrm{N} \\
2.507(2) \\
2.597(2)\end{array}$ & $90.99(6)$ & Not given & $\begin{array}{c}0.14 \\
\left(\mathrm{C}_{6} \mathrm{D}_{6}\right)\end{array}$ & [33] \\
\hline 31 & No RX data & & & & $\begin{array}{c}169.6 \\
{ }^{1} \mathrm{~J}_{\mathrm{C}-\mathrm{Sn}}=409 \mathrm{~Hz}\end{array}$ & $\begin{array}{c}231 \\
\left(\mathrm{C}_{6} \mathrm{D}_{6}\right)\end{array}$ & [33] \\
\hline 32 & No RX data & & & & $\begin{array}{c}167.2 \\
{ }^{1} \mathrm{~J}_{\mathrm{C}-\mathrm{Sn}}=441 \mathrm{~Hz}\end{array}$ & $\begin{array}{c}206 \\
\left(\mathrm{C}_{6} \mathrm{D}_{6}\right) \\
\end{array}$ & [33] \\
\hline 33 & No RX data & & & & $\begin{array}{c}188.2, \mathrm{t} \\
\mathrm{t},{ }^{2} \mathrm{~J}_{\mathrm{C}-\mathrm{P}}=37\end{array}$ & $\begin{array}{c}-100, \mathrm{t} \\
\mathrm{J}_{\mathrm{Sn}-\mathrm{P}}=116 \mathrm{~Hz} \\
\left(\mathrm{Tol}-\mathrm{D}_{8}\right)\end{array}$ & [34] \\
\hline 34 & No RX data & & & & $\begin{array}{c}185.8, t \\
{ }^{2} J_{C-P}=36\end{array}$ & $\begin{array}{c}-68, \mathrm{t} \\
\mathrm{J}_{\mathrm{Sn}-\mathrm{P}}=116 \mathrm{~Hz} \\
\left(\mathrm{Tol}-\mathrm{D}_{8}\right)\end{array}$ & [34] \\
\hline 35 & $2.244(2)$ & $\begin{array}{c}\mathrm{X}=\mathrm{Cl} \\
2.4708(8)\end{array}$ & $\begin{array}{c}\mathrm{E}=\mathrm{O} \\
2.430(2) \\
2.427(2)\end{array}$ & $94.23(3)$ & $\begin{array}{c}186.7, \mathrm{t} \\
{ }^{2} \mathrm{~J}_{\mathrm{C}-\mathrm{P}}=36.3 \\
\end{array}$ & $\begin{array}{c}-99 \\
\mathrm{~J}_{\mathrm{Sn}-\mathrm{P}}=119 \mathrm{~Hz} \\
\left(\mathrm{C}_{6} \mathrm{D}_{6}\right)\end{array}$ & [35] \\
\hline 36 & $2.237(2)$ & $\begin{array}{c}\mathrm{X}=\mathrm{Br} \\
2.6286(3)\end{array}$ & $\begin{array}{c}\mathrm{E}=\mathrm{O} \\
2.463(2) \\
2.420(2)\end{array}$ & 93.73 & $\begin{array}{c}184.6, t \\
{ }^{2} \mathrm{~J}_{\mathrm{C}-\mathrm{P}}=35.3\end{array}$ & $\begin{array}{c}-69 \\
\mathrm{~J}_{\mathrm{Sn}-\mathrm{P}}=118 \mathrm{~Hz} \\
\left(\mathrm{C}_{6} \mathrm{D}_{6}\right)\end{array}$ & [35] \\
\hline 37 & $2.233(2)$ & $\begin{array}{c}X=I \\
2.8544(3)\end{array}$ & $\begin{array}{c}\mathrm{E}=\mathrm{O} \\
2.473(2) \\
2.408(2)\end{array}$ & $94.92(6)$ & $\begin{array}{c}182.6, \mathrm{t} \\
{ }^{2} \mathrm{~J}_{\mathrm{C}-\mathrm{P}}=35.5\end{array}$ & $\begin{array}{c}-22 \\
\mathrm{~J}_{\mathrm{Sn}-\mathrm{P}}=117 \mathrm{~Hz} \\
\left(\mathrm{C}_{6} \mathrm{D}_{6}\right)\end{array}$ & [35] \\
\hline 38 & 2.245 & $\begin{array}{c}\mathrm{X}=\mathrm{Cl} \\
2.454(3)\end{array}$ & $\begin{array}{c}E=O \\
2.458(7) \\
2.543(7)\end{array}$ & $91.1(2)$ & $\begin{array}{c}173.0 \\
\left(\mathrm{CDCl}_{3}\right)\end{array}$ & $\begin{array}{c}-25.6 \\
\left(\mathrm{CDCl}_{3}\right)\end{array}$ & [36] \\
\hline 39 & $2.214(2)$ & $\begin{array}{c}\mathrm{X}=\mathrm{Cl} \\
2.359(13)\end{array}$ & $\begin{array}{c}E=O \\
2.451(12)\end{array}$ & $95.22(3)$ & $\begin{array}{c}169.8 \\
\left(\mathrm{CDCl}_{3}\right) \\
\end{array}$ & $\begin{array}{l}-14.95\left(\mathrm{CDCl}_{3}\right) \\
-33.3\left(\mathrm{THF}-\mathrm{D}_{8}\right)\end{array}$ & [22] \\
\hline 40 & $2.219(2)$ & $\mathrm{X}=\mathrm{Cl}$ & $\mathrm{E}=\mathrm{O}$ & $93.24(4)$ & 171.6 & Two isomers, 49.3 & {$[23]$} \\
\hline
\end{tabular}




\begin{tabular}{|l|c|c|c|l|c|c|c|}
\hline & $2.482(1)$ & Sn1-O sulfoxide & & (THF-D8 $)$ & and $72.5\left(\mathrm{CDCl}_{3}\right)$ & \\
& & & $2.269(2)$ & & & \\
& & & Sn1-O sulfone & & & & \\
\hline
\end{tabular}

The data gathered from the ${ }^{1} \mathrm{H}$ and ${ }^{13} \mathrm{C}$ NMR spectra are in each case characteristic for the ligand backbone. The shift for the $\mathbf{C}_{\text {ipso }}$ carbon atom in the ${ }^{13} \mathrm{C}$ NMR is characteristic for a tin atom linked to an aryl ligand. The ${ }^{119} \mathrm{Sn}$ NMR shows signals varying from 231 to $-100 \mathrm{ppm}$, depending on the nature of the ligand. (Table 3) The solid state structures show similar geometries for both stannylenes and germylenes. In the case of the stannylenes also, the ligands are bonded tridentately to the tin atom, through one $\sigma$ bond to the $\mathbf{C}_{i p s o}$ carbon atom and through intramolecular coordinations between the heteroatoms of the ortho substituents.

The molecular structures determined by X-ray diffraction show that the length of the $\mathrm{N} \rightarrow \mathrm{Sn}$ coordination in the N,C,N-chelating pincer ligand supported stannylenes vary from 2.507(2) to $2.602(8) \AA$ (see Table 3), while in the case of the O,C,O-type pincer ligand stabilized derivatives the $\mathrm{O} \rightarrow \mathrm{Sn}$ bond takes values from 2.269(2) to 2.656(1) $\AA$ (see Table 3). The Sn-Cl bond is orthogonal with respect to the aryl ring $\left(90.99(6)-95.22(3)^{\circ}\right)$, similar to the case of the germylenes.

\subsection{Reactivity of stannylenes}

The reactivity of the pincer-stannylene derivatives is similar to those of the germylenes. It is thus a general characteristic of metallylenes to undergo substitution reactions at the halogen atom, coordination reactions through the lone pair electrons, and oxidative additions as well.

Chlorostannylene $\mathrm{L}^{\mathrm{I}} \mathrm{SnCl} 27\left(\mathrm{~L}^{\mathrm{I}}=2,6-\left(\mathrm{Me}_{2} \mathrm{NCH}_{2}\right)_{2} \mathrm{C}_{6} \mathrm{H}_{3}\right)$ presents a vast reactivity. By reaction with 4-tolyl-lithium, substitution of the chlorine atom took place, leading to diaryltin(II) derivative 41 (Scheme 9). This further reacted with methyl-iodide, where through an oxidative addition forms ionic tin(IV) iodide 42. When iodine was added to the diaryl stannylene, heaxacoordinate $\mathrm{Sn}(\mathrm{IV})$ species $\mathbf{4 3}$ was obtained, as depicted in Scheme 9. ${ }^{[13]}$

Reaction of stannylene 27 with $\left\{\mathrm{LiN}\left(\mathrm{BCy}_{2}\right)\left(\mathrm{C}_{6} \mathrm{H}_{3}-2,6-\mathrm{Me}_{2}\right)\right\}_{2}$, lithium salt of aminoborane $\mathrm{HN}\left(\mathrm{BCy}_{2}\right)\left(\mathrm{C}_{6} \mathrm{H}_{3}-2,6-\mathrm{Me}_{2}\right)$ led to $\mathrm{N} \rightarrow \mathrm{Sn}$ coordinated stannylene $\mathrm{L}^{\mathrm{I}} \mathrm{Sn}\left[\mathrm{N}(\mathrm{BCy})\left(\mathrm{C}_{6} \mathrm{H}_{3}-2,6-\mathrm{Me}_{2}\right)\right] .{ }^{[37]}$ Moreover, in order to study the acid/base Lewis behaviour of $\mathbf{2 7}$, the reaction with naphthalene derivatives containing Lewis acid groups $\left(\mathrm{BCy}_{2}\right)$ or Lewis bases $\left(\mathrm{PPh}_{2}, \mathrm{~L}^{\mathrm{I}} \mathrm{Sn}\right)$ were studied. ${ }^{[38]}$ The interactions between the $\mathrm{Sn}(\mathrm{II})$ atom and the Lewis acid groups was demonstrated while the interactions between the $\mathrm{Sn}(\mathrm{II})$ atom and the Lewis bases groups was not identified. 


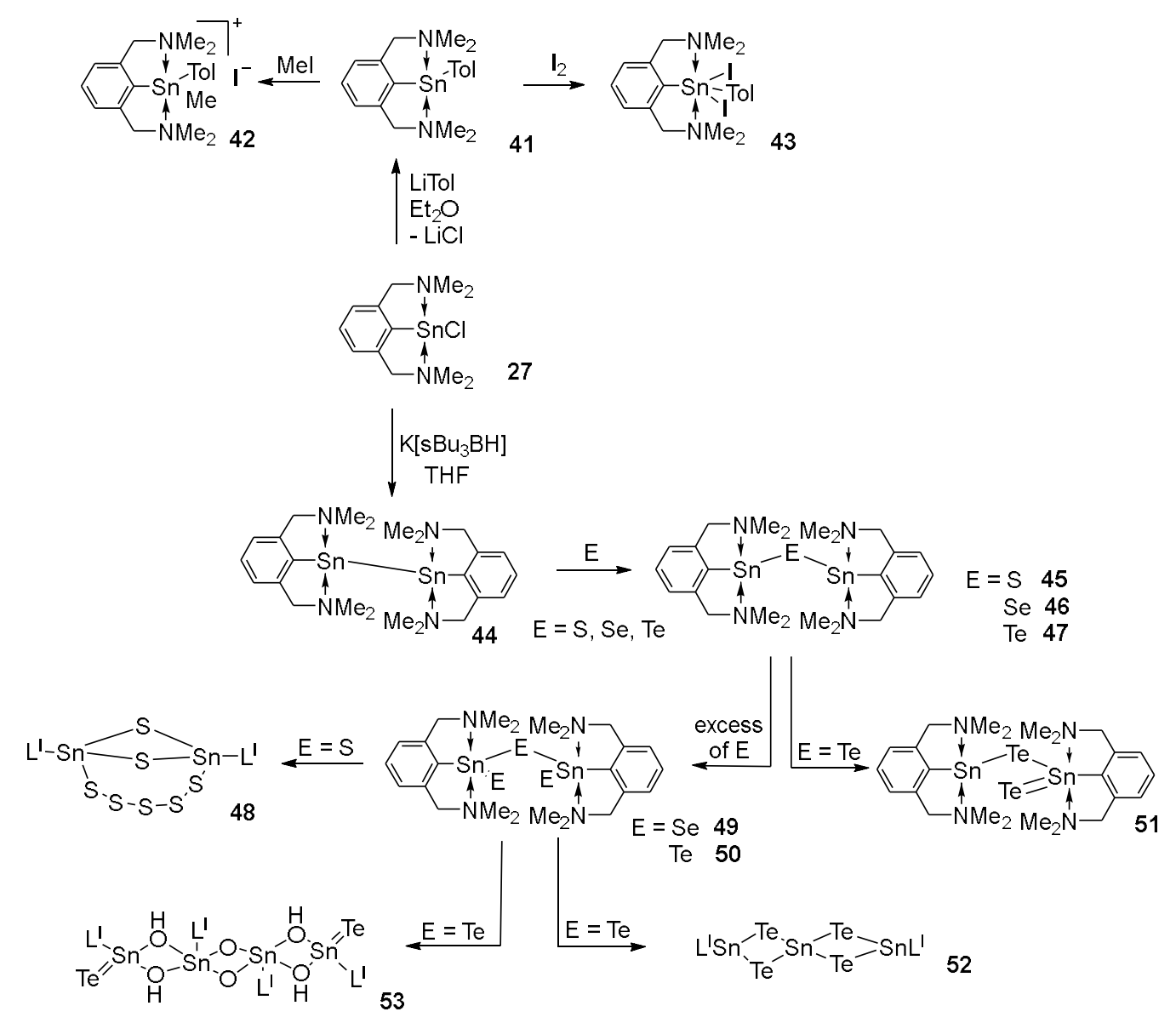

Scheme 9. Reactivity of the stannylene $\mathbf{2 7}$

The reaction of chlorostannylene $\mathbf{2 7}$ with $\mathrm{K}\left[s \mathrm{Bu}_{3} \mathrm{BH}\right]$ led to the formation of a diorganodistannyne 44, as shown in Scheme 9. ${ }^{[39]}$ The data obtained from the X-ray analysis showed that the Sn-Sn bond length of 2.9712(12) $\AA$ is in the range of a tin-tin single bond. ${ }^{[4]}$ The $\mathrm{N} \rightarrow \mathrm{Sn}$ distances of 2.585(9) and of 2.631(9) $\AA$ are values close to the ones seen in the starting chlorostannylene $27 .{ }^{[39]}$

The thus obtained diorganostannyne 44 undergoes oxidation in the presence of $\mathrm{S}_{8}$, Se and Te, forming organotin(II) chalcogenides containing the Sn-E-Sn unit $(E=S, S e, T e)$, as shown in Scheme 9. The formation of these compounds was explained through a two-step oxidation followed by the cleavage of the Sn-Sn bond. All the stable tin(II) chalcogenides $45(\mathrm{E}=\mathrm{S}),{ }^{[40]} 46(\mathrm{E}=\mathrm{Se}),{ }^{[41]} 47(\mathrm{E}=\mathrm{Te})^{[42]}$ were characterized by NMR spectroscopy and X-ray diffraction, revealing the structural characteristics of divalent tin species. The bond lengths obtained from solid state data indicate that the tin-chalcogene display distances in the range of single bonds. (See Table 4) 
Table 4. Chemical-physical data for N,C,N-pincer stabilized L ${ }^{\mathrm{I}} \mathrm{SnCl}$ stannylene derivatives.

\begin{tabular}{|c|c|c|c|c|c|c|c|}
\hline & \begin{tabular}{|c|} 
Cipso-Sn $_{\text {-Sn }}$ \\
bond length \\
$(\AA)$ \\
\end{tabular} & $\begin{array}{l}\text { Sn-R bond } \\
\text { length }(\AA)\end{array}$ & $\begin{array}{c}\mathbf{E} \rightarrow \text { Sn bond length } \\
(\AA ̊)\end{array}$ & $\begin{array}{c}\mathrm{C}_{i p s o}-\mathrm{Sn}-\mathrm{R} \text { bond } \\
\text { angle }\left({ }^{\circ}\right)\end{array}$ & $\begin{array}{c}{ }^{13} \mathrm{C} \text { NMR } \\
\delta \mathrm{C}_{\text {ipso }}(\mathrm{ppm}) \\
\text { (solvent) } \\
\end{array}$ & $\begin{array}{c}{ }^{119} \text { Sn NMR } \\
\text { (ppm) } \\
\text { (solvent) } \\
\end{array}$ & Ref \\
\hline 41 & No RX data & & & & $\begin{array}{c}169.5 \\
{ }^{1} \mathrm{~J}_{\mathrm{C}-\mathrm{Sn}}=272 \mathrm{~Hz} \\
\left(\mathrm{Tol}_{-} \mathrm{D}_{8}\right)\end{array}$ & $\begin{array}{c}209.6 \\
\text { (Tol-D8) }\end{array}$ & [13] \\
\hline 43 & No RX data & & & & Not found & -208.7 & [13] \\
\hline 44 & $\begin{array}{l}2.180(11) \\
2.193(10)\end{array}$ & $\begin{array}{c}\text { Sn-Sn } \\
2.9712(12)\end{array}$ & $\begin{array}{c}2.631(9), 2.593(10) \\
2.585(9), 2.612(7)\end{array}$ & $\begin{array}{c}\text { C }_{\text {ipso }}-\mathrm{Sn}-\mathrm{Sn} \\
94.3(3) \\
94.1(2)\end{array}$ & Not found & $\begin{array}{c}612 \\
\left(\mathrm{C}_{6} \mathrm{D}_{6}\right)\end{array}$ & [39] \\
\hline 45 & $\begin{array}{l}2.188 \\
2.197\end{array}$ & $\begin{array}{c}\text { Sn-S } \\
2.4758(11) \\
2.4889(11) \\
\end{array}$ & $\begin{array}{l}2.584(4), 2.637(3) \\
2.652(3), 2.594(3)\end{array}$ & $\begin{array}{c}\mathbf{C}_{\text {ipso }}-\mathrm{Sn}-\mathrm{S} \\
94.27(11) \\
97.11(1)\end{array}$ & $\begin{array}{l}172.5 \\
\left(\mathrm{C}_{6} \mathrm{D}_{6}\right)\end{array}$ & $\begin{array}{c}289.3 \\
\left(\mathrm{C}_{6} \mathrm{D}_{6}\right)\end{array}$ & {$[40]$} \\
\hline 46 & $\begin{array}{l}2.190(3) \\
2.189(3)\end{array}$ & $\begin{array}{c}\mathrm{Sn}-\mathrm{Se} \\
2.5944(5) \\
2.6056(5) \\
\end{array}$ & $2.546(3)$ & $\begin{array}{c}\mathbf{C}_{\boldsymbol{i p s o} \text {-Sn-Se }} \\
94.58(8) \\
92.23(8) \\
\end{array}$ & Not assigned & 309.5 & [41] \\
\hline 47 & $\begin{array}{l}2.187 \\
2.188\end{array}$ & $\begin{array}{c}\text { Sn-Te } \\
2.8218(7) \\
2.8334(8) \\
\end{array}$ & $\begin{array}{l}2.520,2.685 \\
2.589,2.573\end{array}$ & $\begin{array}{c}\mathbf{C}_{\boldsymbol{i p s o}}-\mathrm{Sn}-\mathrm{Se} \\
95.1(2) \\
95.0(2) \\
\end{array}$ & $\begin{array}{l}168.7 \\
\left(\mathrm{C}_{6} \mathrm{D}_{6}\right)\end{array}$ & $\begin{array}{l}67.8 \\
\left(\mathrm{C}_{6} \mathrm{D}_{6}\right)\end{array}$ & [42] \\
\hline 48 & $\begin{array}{l}2.141 \\
4.142\end{array}$ & $\begin{array}{c}\text { Sn-S } \\
2.4058(12)- \\
2.4468(12) \\
\end{array}$ & $\begin{array}{l}2.877(4), 2.882(4) \\
2.976(3), 2.663(4)\end{array}$ & $\begin{array}{c}\mathrm{C}_{\text {ipso }}-\mathrm{Sn}-\mathrm{S} \text { (bridge) } \\
109.2-118.55\end{array}$ & $\begin{array}{c}143.5 \\
\left(\mathrm{C}_{6} \mathrm{D}_{6}\right)\end{array}$ & $\begin{array}{l}-140.1 \\
\left(\mathrm{C}_{6} \mathrm{D}_{6}\right)\end{array}$ & {$[40]$} \\
\hline 49 & $2.115(5)$ & $\begin{array}{l}\mathrm{Sn}-\mathrm{Se} \text { (bridge) } \\
2.5297(6) \\
\mathrm{Sn}=\mathrm{Se} \\
2.3891(6)\end{array}$ & $\begin{array}{l}2.535(5) \\
2.442(3)\end{array}$ & $\begin{array}{c}\mathbf{C}_{i p s o}-\mathrm{Sn}-\mathrm{Se} \text { (bridge) } \\
106.39(13) \\
\text { Cipso }_{\text {ipn-Se }}-\mathrm{Se} \text { (terminal) } \\
127.84(13)\end{array}$ & Not assigned & $\begin{array}{c}-173.4 \\
{ }^{2} \mathrm{~J}\left({ }^{119} \mathrm{Sn}-\right. \\
\left.{ }^{117} \mathrm{Sn}\right)=186 \mathrm{~Hz} \\
{ }^{1} \mathrm{~J}(\mathrm{Sn}, \mathrm{Se})=1503 \\
\mathrm{~Hz} \\
\left(\mathrm{C}_{6} \mathrm{D}_{6}\right)\end{array}$ & {$[41]$} \\
\hline 50 & No RX data & & & & 138.9 & $\begin{array}{c}-84.6 \\
{ }^{1} \mathrm{~J}_{\mathrm{Sn}-\mathrm{Te}}=7418 \mathrm{~Hz} \\
\left(\mathrm{C}_{6} \mathrm{D}_{6}\right)\end{array}$ & {$[42]$} \\
\hline 51 & $\begin{array}{l}2.193 \\
2.133\end{array}$ & $\begin{array}{c}\mathrm{Sn}-\mathrm{Te} \text { (bridge) } \\
2.8974(3) \text { and } \\
2.7270(3) \\
\mathrm{Sn}^{-\mathrm{Te}} \text { (terminal) } \\
2.6110(4)\end{array}$ & $\begin{array}{l}2.678,2.554 \\
2.535,2.490\end{array}$ & $\begin{array}{c}\text { Cipso-Sn-Te (bridge) }_{\text {ip }} \text { - } \\
\text { 93.79(9), 105.2(1) } \\
\text { Cipso-Sn-Te (terminal) }_{\text {ips }} \text {-Sn } \\
131.86\end{array}$ & 145.1 & $\begin{array}{l}-131 \\
\left(\mathrm{C}_{6} \mathrm{D}_{6}\right)\end{array}$ & [42] \\
\hline 52 & 2.117 & $\begin{array}{c}\mathrm{Sn}-\mathrm{Te} \\
2.6633(5)- \\
3.2162(4)\end{array}$ & $\begin{array}{l}2.474 \\
2.501\end{array}$ & $\begin{array}{c}\mathbf{C}_{\text {ipso }} \text {-Sn-Te } \\
120.18 \\
132.55\end{array}$ & Not found & $\begin{array}{c}-294.4,-295.0 \\
-379.3 \\
(\text { THF-D } 8)\end{array}$ & [42] \\
\hline 53 & $\begin{array}{l}2.133 \\
2.138\end{array}$ & $\begin{array}{l}\mathrm{Sn}-\mathrm{Te} \\
2.638\end{array}$ & $\begin{array}{l}2.510,2.715 \\
2.318,3.728 \\
\end{array}$ & & No data & $\begin{array}{c}-424,-444 \\
\left(\mathrm{C}_{6} \mathrm{D}_{6}\right)\end{array}$ & [42] \\
\hline
\end{tabular}


The Sn-N distances display values between 2.520 and $2.685 \AA$ in all three cases, presenting no significant variation from the values found in the distannyne 44. ${ }^{[40]}$ When Se was used as oxidizing agent, a longer reaction time led to organotin(IV) selenide 49, containing the Sn-Se-Sn moiety and two terminal $\mathrm{Sn}=\mathrm{Se}$ bonds. ${ }^{[41]}$ The formation of analogous compounds were evidenced in the case of sulphur and tellurium, the organotin(IV) polysulfide $48,{ }^{[40,43]}$ its formation explained through a sulphide intermediate and tellurium, derivative $\mathbf{5 0}{ }^{[42]}$, as shown in Scheme 9. Compound $\mathbf{5 0}$ was revealed to be unstable, decomposing to $\mathbf{5 2}$, while in the presence of moisture gave the stannaoxane 53. In the case of tellurium, the unsymmetrical compound $\mathbf{5 1}$ was also obtained, containing tin atoms in both + II and +IV oxidation states. ${ }^{[42]}$ DFT calculations on the tellurium containing derivatives showed highly positive charges on the tin atoms stabilized through the intramolecular coordination of the N,C,N-pincer ligand. ${ }^{[42]}$ Derivative 44 in reaction with diorgano disulfides formed the corresponding organotin(II) thio derivatives. ${ }^{[44]}$ The redox potential of the tin atom in the diorganodistannyne $\mathrm{L}^{\mathrm{I}} \mathrm{SnSnL}^{\mathrm{I}}\left[\mathrm{L}^{\mathrm{I}}=2,6-\left(\mathrm{R}_{2} \mathrm{NCH}_{2}\right)_{2} \mathrm{C}_{6} \mathrm{H}_{3}, \mathrm{R}=\mathrm{Me}\right],{ }^{[45]}$ as well as the reduction ability of these type of distannynes were also studied. ${ }^{[46]}$

The coordination ability of chlorostannylene $\mathbf{2 7}$ was tested towards different transition metal complexes, as show in Scheme 10. The Pd(II) atom in complexes 54, 55, 59 is in a square planar geometry, while the $\mathrm{Sn}$ atom adopts a trans trigonal bipyramidal geometry. The coordination of $\mathrm{Pd}(\mathrm{II})$ atom on the Sn one let unaffected the Sn-N interactions. ${ }^{[47,48]}$

In complex 61, obtained through the coordination of chlorostannylene $\mathbf{2 7}$ to the ruthenium atom, ruthenium adopts an octahedral geometry and the tin atom is 5-fold coordinated in a distorted square-pyramidal geometry. ${ }^{[49]}$

When $\left(\mathrm{PPh}_{3}\right)_{2} \mathrm{PdCl}_{2}{ }^{[47]}$ or $\mathrm{Pd}\left(\mathrm{PPh}_{3}\right)_{4}{ }^{[48]}$ were used in order to obtained new complexes containing a $\mathrm{L}^{\mathrm{I}} \mathrm{SnCl}$ unit as ligand, the dimeric compound $\mathbf{5 6}$ was obtained, containing a $\mathrm{PdCl}_{2}$ moiety bridging two $\mathrm{L}^{\mathrm{I}} \mathrm{SnCl}$ molecules. ${ }^{[47,48]}$ In the presence of $\mathrm{PdI}_{2}$, iodide-substituted palladium complex 66 was formed, with a similar structure as compound 56, ${ }^{[50]}$ with $\mathrm{PtCl}_{2} \mathbf{2 7}$, complex 57 was observed and through reaction with $\mathrm{NaI}$, the iodine substituted analogue $\mathbf{5 8}$ was obtained (Scheme 10). ${ }^{[50]}$ In the last three examples the coordination geometry of the tin atom was described as a distorted trigonal bipyramidal one. ${ }^{[50]}$

Complexes $\mathbf{5 4}^{[47]}$ and $\mathbf{5 9}^{[49]}$, containing Pd(II) atom were also obtained and characterized. The chlorine atom, bonded to the tin atom in complex $\mathbf{5 4}$, was substituted with an acetate group in the presence of AgOAc, thus the new monoacetate complex $\mathbf{5 5}$ was obtained, as shown in Scheme 10. ${ }^{[48]}$

Ruthenium, rhodium and molybdenum complexes 60-65 were obtained starting from chlorostannylene 27 through reaction with $\left[\left(\eta^{6} \text {-benzene }\right) \mathrm{RuCl}\right]_{2}(\mu-\mathrm{Cl})_{2}$ or $\left[\left(\eta^{6} \text { - cymene }\right) \mathrm{RuCl}\right]_{2}(\mu$ $\mathrm{Cl})_{2},{ }^{[49]}\left[(\mathrm{CO})_{3} \mathrm{RuCl}\right]_{2}(\mu-\mathrm{Cl})_{2},{ }^{[49]}\left[(\mathrm{CO})_{2} \mathrm{Rh}\right]_{2}(\mu-\mathrm{Cl})_{2}{ }^{[49]}$ and $\left[\mathrm{Mo}(\mathrm{CO})_{2}\left(\mathrm{CH}_{3} \mathrm{CN}\right)_{2} \mathrm{Cp}\right]^{+} \mathrm{BF}_{4}{ }^{-}{ }^{[48]}$ In the case of the molybdenum complex the observed structure of "four-legged piano stool motif" is considered typical for $\mathrm{CpMoL}_{4}$ type complexes. The geometrical parameters of compound $\mathbf{6 5}$ suggest a strong donor character of the stannylene. ${ }^{[48]}$ 

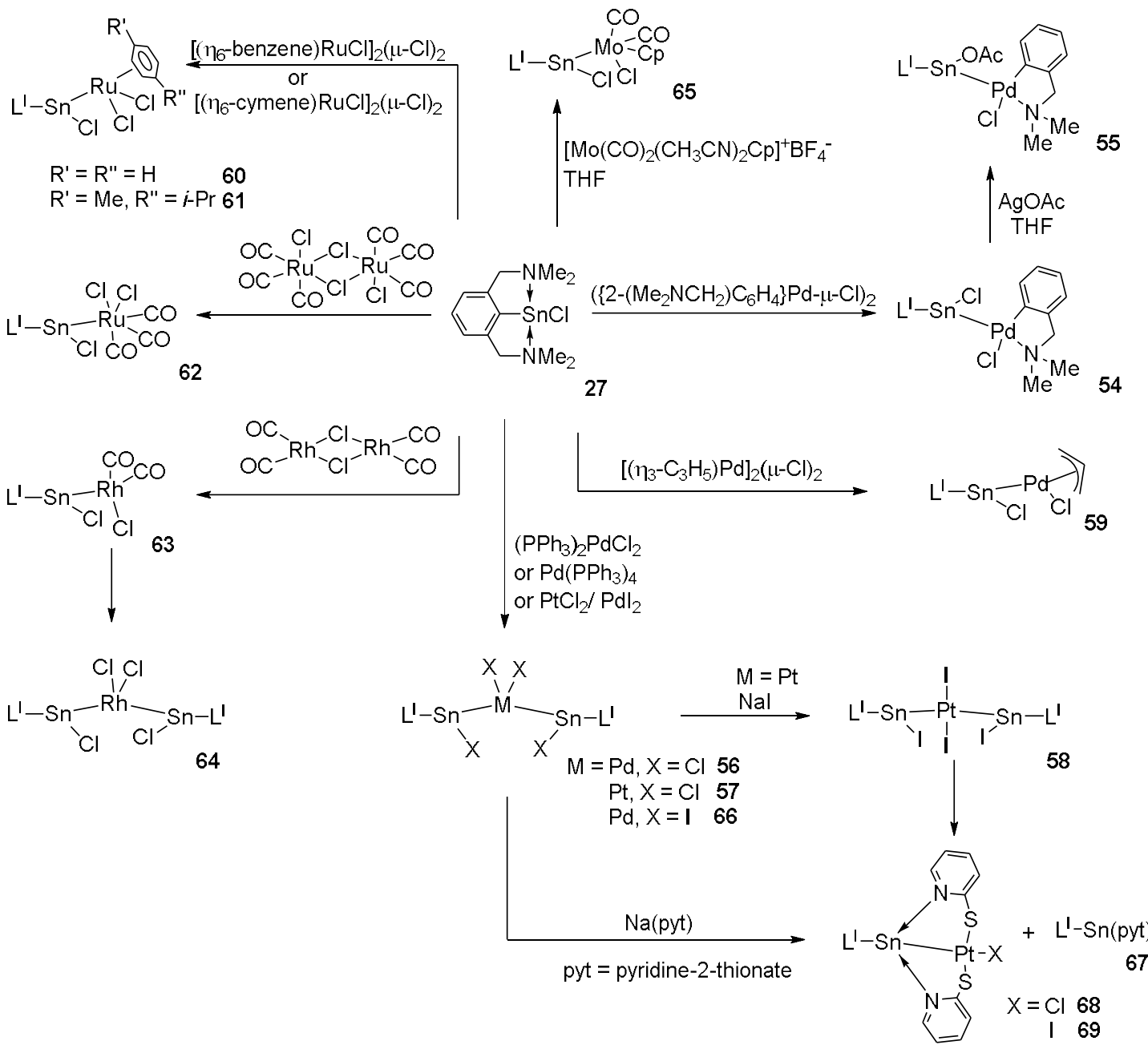

Scheme 10. Reactivity of the chlorostannylene 27 towards transition metal complexes

Similarly to the palladium complexes of stannylene 27, platinum complexes were obtained and characterized, the reactions are depicted in Scheme 10. In both cases the tin atoms are pentacoordinated, with the Sn-Pt distances of 2.4865(4) (Cl substituted Pt, 57) and 2.5532(5) $\AA$ (I substituted Pt, 58) and the Sn-N interactions between 2.439(4) and 4.526(5) Å. The iodine substituted platinum complex $\mathbf{5 8}$ was formed by adding $\mathrm{NaI}$ to the chlorine substituted stannylene-platinum complex 57. A halogen exchange reaction was observed on the tin and platinum atoms and the formation of the trans isomer, considering the halogen atoms. ${ }^{[50]}$

The platinum complexes 57 and $\mathbf{5 8}$ in the presence of $\mathrm{Na}$ (pyt) (pyt = pyridine-2-thionate) formed new complexes $\mathbf{6 8}$ and $\mathbf{6 9}$. The geometrical parameters of the new complexes (see Table 5) determined by single crystal X-ray diffraction, completed by an NBO analysis, showed that the tinplatinum interactions were formed through the donation from a stannylidenium $\left(\mathrm{ArSn}^{\mathrm{II}}\right)^{+}$fragment to a $\left[\mathrm{Pt}(\mathrm{pyt})_{2} \mathrm{Cl}\right]^{-}$anion, the lone electron pair of the tin being shared between this and the platinum atom, forming a tin-platinum covalent bond and a $\mathrm{Pt}^{0} \rightarrow \mathrm{Sn}^{\mathrm{IV}}$ interaction. ${ }^{[51,52]}$ In both cases a pyridine-2thionate coordinated stannylene $\mathbf{6 7}$ was also formed as a secondary product. ${ }^{[1,52]}$ 
Table 5. Chemical-physical data for N,C,N-pincer stabilized $\mathrm{L}^{\mathrm{I}} \mathrm{SnCl}$ stannylene derivatives

\begin{tabular}{|c|c|c|c|c|c|c|c|c|}
\hline & $\begin{array}{c}C_{i p s o}-\text { Sn } \\
\text { bond } \\
\text { length }(\AA)\end{array}$ & $\begin{array}{l}\text { Sn-R bond } \\
\text { length }(\AA)\end{array}$ & $\begin{array}{c}\text { Sn-M } \\
\text { bond } \\
\text { length }(\AA)\end{array}$ & \begin{tabular}{|c|}
$\mathrm{N} \rightarrow \mathrm{Sn}$ \\
bond \\
length $(\AA)$
\end{tabular} & $\begin{array}{l}\mathrm{C}_{i p s o}-\mathrm{Sn}-\mathrm{R} \text { bond } \\
\text { angle }\left(^{\circ}\right)\end{array}$ & 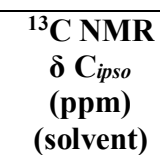 & $\begin{array}{c}{ }^{119} \text { Sn NMR } \\
\text { (ppm) } \\
\text { (solvent) }\end{array}$ & Ref \\
\hline 54 & $2.117(6)$ & $\begin{array}{l}\mathrm{Sn}-\mathrm{Cl} \\
2.431(2)\end{array}$ & $\begin{array}{l}\text { Sn-Pd } \\
2.4956(8)\end{array}$ & $\begin{array}{l}2.424(5) \\
2.504(5)\end{array}$ & $\begin{array}{l}\text { C }_{\text {ipso }} \text {-Sn-Cl 97.19(15) } \\
\text { Cipso }_{\text {ipn-Pd }} \\
138.18(14)\end{array}$ & $\begin{array}{l}\text { Not } \\
\text { assigned }\end{array}$ & $\begin{array}{l}-76.5 \\
\left(\mathrm{C}_{6} \mathrm{D}_{6}\right)\end{array}$ & [47] \\
\hline 55 & $2.123(4)$ & $\begin{array}{l}\mathrm{R}=\mathrm{OAc} \\
2.097(3)\end{array}$ & $\begin{array}{l}\mathrm{M}=\mathrm{Pd} \\
2.4972(6)\end{array}$ & $\begin{array}{l}2.441(3) \\
2.533(3)\end{array}$ & $\begin{array}{l}\mathbf{C}_{i p s o}-\mathrm{Sn}-\mathrm{O} \\
100.52(14) \\
\mathbf{C}_{i p s o}-\mathrm{Sn}-\mathrm{Pd} \\
132.93(11) \\
\end{array}$ & $\begin{array}{l}\text { Not } \\
\text { assigned }\end{array}$ & $\begin{array}{l}-202 \\
\left(\mathrm{C}_{6} \mathrm{D}_{6}\right)\end{array}$ & [48] \\
\hline 56 & $2.121(1)$ & $\begin{array}{l}\mathrm{R}=\mathrm{Cl} \\
2.384(4)\end{array}$ & $\begin{array}{l}\mathrm{M}=\mathrm{Pd} \\
2.5197(9)\end{array}$ & $\begin{array}{l}2.422(1) \\
2.499(1) \\
\end{array}$ & $\begin{array}{l}\mathbf{C}_{i p s o}-\text { Sn-Cl 97.2(4) } \\
\mathbf{C}_{i p s o}-\text { Sn-Pd 137.9(4) }\end{array}$ & $\begin{array}{l}\text { Not } \\
\text { assigned }\end{array}$ & $\begin{array}{l}-122.3 \\
\left(\mathrm{CDCl}_{3}\right)_{3} \\
\end{array}$ & [47] \\
\hline 57 & $2.115(5)$ & $\begin{array}{l}\mathrm{R}=\mathrm{Cl} \\
2.3828(15)\end{array}$ & $\begin{array}{l}\mathrm{M}=\mathrm{Pt} \\
2.4865(4)\end{array}$ & $\begin{array}{l}2.487(4) \\
2.439(4)\end{array}$ & $\begin{array}{l}\text { Cipso-Sn-Cl 98.74(14) }_{\text {Cipso-Sn-Pt 138.6(1) }} \\
\text { C }_{\text {ipt }}\end{array}$ & $\begin{array}{l}\text { Not } \\
\text { assigned }\end{array}$ & $\begin{array}{l}-254 \\
{ }^{1} \mathrm{~J}_{\mathrm{Sn}-\mathrm{Pt}} \\
=12640 \mathrm{~Hz} \\
\left(\mathrm{CDCl}_{3}\right)\end{array}$ & [50] \\
\hline 58 & $2.112(6)$ & $\begin{array}{l}\mathrm{R}=\mathrm{I} \\
2.7672(6) \\
\end{array}$ & $\begin{array}{l}\mathrm{M}=\mathrm{Pt} \\
2.5532(5)\end{array}$ & $\begin{array}{l}2.467(5) \\
2.526(5) \\
\end{array}$ & $\begin{array}{l}\mathbf{C}_{\boldsymbol{i p s} s}-\text { Sn-I 101.8(2) } \\
\mathbf{C}_{\boldsymbol{i p s} \boldsymbol{s}} \text {-Sn-Pt 138.2(2) } \\
\end{array}$ & $\begin{array}{l}\text { Not } \\
\text { assigned }\end{array}$ & $\begin{array}{l}-80 \mathrm{ppm} \\
\left(\mathrm{CDCl}_{3}\right) \\
\end{array}$ & [50] \\
\hline 59 & $2.121(5)$ & $\begin{array}{l}\mathrm{R}=\mathrm{Cl} \\
2.4384(14)\end{array}$ & $\begin{array}{l}\mathrm{M}=\mathrm{Pd} \\
2.5556(5)\end{array}$ & $\begin{array}{l}2.456(4) \\
2.507(4)\end{array}$ & $\begin{array}{l}\text { Cipso-Sn-Cl 99.14(14) } \\
\text { Cipso-Sn-Pd }_{148.24(14)}\end{array}$ & $\begin{array}{l}\text { Not } \\
\text { assigned }\end{array}$ & $\begin{array}{l}126.0 \\
\left(\mathrm{C}_{6} \mathrm{D}_{6}\right)\end{array}$ & [49] \\
\hline 60 & $\begin{array}{l}\text { No RX } \\
\text { data }\end{array}$ & & & & & $\begin{array}{l}\text { Not } \\
\text { assigned }\end{array}$ & $\begin{array}{l}-109.9 \\
\left(\mathrm{C}_{6} \mathrm{D}_{6}\right)\end{array}$ & [49] \\
\hline 61 & $2.122(3)$ & $\begin{array}{l}\mathrm{R}=\mathrm{Cl} \\
2.4362(8)\end{array}$ & $\begin{array}{l}\mathrm{M}=\mathrm{Ru} \\
2.5934(3)\end{array}$ & $\begin{array}{l}2.492(3) \\
2.542(3)\end{array}$ & $\begin{array}{l}\text { C }_{\text {ipso-Sn-Cl 99.14(14) }} \\
\text { Cipso-Sn-Ru }_{\text {ips }} \text {-Ru } \\
148.24(14)\end{array}$ & $\begin{array}{l}\text { Not } \\
\text { assigned }\end{array}$ & $\begin{array}{l}-128.2 \\
\left(\mathrm{CDCl}_{3}\right)\end{array}$ & [49] \\
\hline 62 & $\begin{array}{l}\text { No RX } \\
\text { data }\end{array}$ & & & & & $\begin{array}{l}\text { Not } \\
\text { assigned }\end{array}$ & $\begin{array}{l}26.4 \\
\left(\mathrm{CDCl}_{3}\right) \\
\end{array}$ & [49] \\
\hline 63 & $\begin{array}{l}\text { No RX } \\
\text { data }\end{array}$ & & & & & $\begin{array}{l}152.3 \\
{ }^{2} J_{\mathrm{C}-\mathrm{Rh}}=9 \mathrm{~Hz}\end{array}$ & $\begin{array}{l}60.8 \\
\left(\mathrm{CDCl}_{3}\right)\end{array}$ & [49] \\
\hline 64 & $2.118(4)$ & $\begin{array}{l}\mathrm{R}=\mathrm{Cl} \\
2.4192(12)\end{array}$ & $\begin{array}{l}\mathrm{M}=\mathrm{Rh} \\
2.5485(4)\end{array}$ & $\begin{array}{l}2.468(4) \\
2.503(3)\end{array}$ & $\begin{array}{l}\text { Cipso-Sn-Cl }-\mathrm{Cl} \\
100.76(12) \\
\text { Cipso-Sn-Rh }_{\text {-Sn }} \\
139.99(12)\end{array}$ & No data & No data & [49] \\
\hline 65 & $2.120(10)$ & $\begin{array}{l}\mathrm{R}=\mathrm{Cl} \\
2.452(2)\end{array}$ & $\begin{array}{l}\mathrm{M}=\mathrm{Mo} \\
2.7195(9) \\
\end{array}$ & $\begin{array}{l}2.494(6) \\
2.567(7) \\
\end{array}$ & $\begin{array}{l}\text { C }_{\boldsymbol{i p s o}}-\mathrm{Sn}-\mathrm{Cl} \text { 98.0(2) } \\
\mathbf{C}_{\boldsymbol{i p s} \text { - }} \text {-Sn-Mo 145.8(2) }\end{array}$ & $\begin{array}{l}\text { Not } \\
\text { assigned }\end{array}$ & $\begin{array}{l}105.4 \\
\left(\mathrm{CDCl}_{3}\right)\end{array}$ & {$[48]$} \\
\hline 66 & $2.128(8)$ & $\begin{array}{l}\mathrm{R}=\mathrm{Cl} \\
2.470(2)\end{array}$ & $\begin{array}{l}\mathrm{M}=\mathrm{Pd} \\
2.5138(9)\end{array}$ & $\begin{array}{l}2.437(7) \\
2.534(7)\end{array}$ & 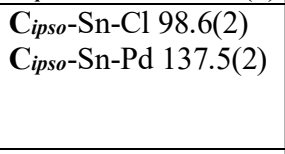 & $\begin{array}{l}\text { Not } \\
\text { assigned }\end{array}$ & $\begin{array}{l}-20 \\
\mathrm{~J}_{\mathrm{Sn}-\mathrm{Sn}}=3885 \\
\mathrm{~Hz} \\
\left(\mathrm{CDCl}_{3}\right) \\
\end{array}$ & [50] \\
\hline 67 & No data & & & & & & $\begin{array}{l}135.1 \\
\left(\mathrm{C}_{6} \mathrm{D}_{6}\right)\end{array}$ & {$[51,52]$} \\
\hline 68 & $2.107(5)$ & $\begin{array}{l}\mathrm{R}=\mathrm{N}(\mathrm{pyt}) \\
2.427(4) \\
2.391(4)\end{array}$ & $\begin{array}{l}\mathrm{M}=\mathrm{Pt} \\
2.4662(4)\end{array}$ & $\begin{array}{l}2.443(4) \\
2.425(4)\end{array}$ & $\begin{array}{l}\text { C }_{\text {ipso }} \text {-Sn-N(pyt) } 88.76 \\
86.15 \\
\text { Cipso-Sn-Pt }_{\text {ips }} \\
177.77(14)\end{array}$ & Not seen & $\begin{array}{l}135 \\
\left(\mathrm{CDCl}_{3}\right)\end{array}$ & {$[52]$} \\
\hline 69 & $2.127(8)$ & $\begin{array}{l}\mathrm{R}=\mathrm{N}(\text { pyt }) \\
2.414(4)\end{array}$ & $\begin{array}{l}\mathrm{M}=\mathrm{Pt} \\
2.4712(5)\end{array}$ & $\begin{array}{l}\mathrm{E}=\mathrm{N} \\
2.437(5)\end{array}$ & $\begin{array}{l}\mathbf{C}_{\text {ipso }}-\mathrm{Sn}-\mathrm{Pt} \\
180.00\end{array}$ & No data & No data & [51] \\
\hline
\end{tabular}


Stannylene tungsten $\mathrm{L}^{\mathrm{I}} \mathrm{Sn}(\mathrm{Cl}) \mathrm{W}(\mathrm{CO})_{5} \mathbf{7 1}$ and chromium $\mathrm{L}^{\mathrm{I}} \mathrm{Sn}(\mathrm{Cl}) \mathrm{Cr}(\mathrm{CO})_{5} \mathbf{7 0}$ complexes were also obtained, as shown in scheme 11 , by adding $(\mathrm{CO})_{5} \mathrm{WSnCl}_{2} \mathrm{THF}$ or $(\mathrm{CO})_{5} \mathrm{CrSnCl}_{2} \mathrm{THF}$ to the carbanion L Li. In complex $\mathbf{7 1}$ the tin atom is five-coordinated with a distorted square-pyramidal configuration and the Sn-N distances are of 2.543(3) and 2.5526(3) $\AA .{ }^{[53]}$ The reactivity of the complexes was tested towards different reagents, mainly to substitute the halogen atom, as depicted in Scheme 11. The reaction of complex 71 with $\mathrm{AgCB}_{11} \mathrm{H}_{12}$ led to organostannylidenium carboranate aqua complex 75, where the tin atom display a 4-fold coordination within strongly distorted tetrahedral geometry. The water molecule is coordinated to the tin atom, further stabilization being achieved thanks to the hydrogen bond formed between this water molecule and the nitrogen atom of one of the flanking dimethylaminomethyl groups. ${ }^{[53]}$<smiles>CN1Cc2cccc3c2[N@@+](Cl)(C(C)(C)C)[N+]1(C)C3</smiles>

70 $\uparrow_{-\mathrm{LiCl}}^{(\mathrm{CO})_{5} \mathrm{CrSnCl}_{2} \cdot \mathrm{THF}}$<smiles>CN(C)Cc1cccc(CN(C)C)c1Cl</smiles>

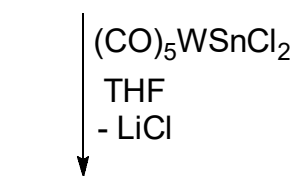

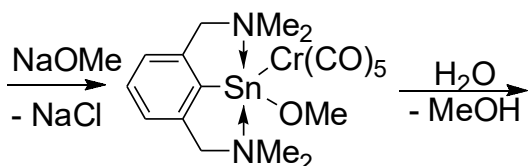

72<smiles>CN1Cc2cccc3c2[N@@+]1([N+](C)(Cl)Cl)[NH+](C)C3</smiles>
71 $\mathrm{K}\left[\mathrm{sBu} \mathrm{BH}_{3} \mathrm{BH}\right.$ $-\mathrm{KCl},-\mathrm{sBu}_{3} \mathrm{~B}$
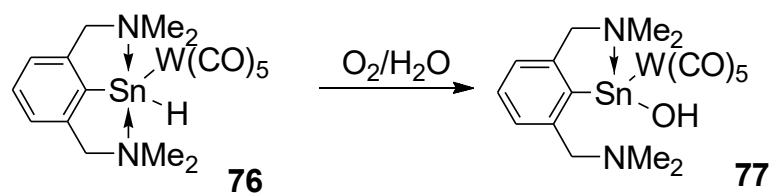

Scheme 11. Synthesis and reactivity of N,C,N-pincer stabilized stannylene-metal complexes 
In reaction with $\mathrm{K}\left[s \mathrm{Bu}_{3} \mathrm{BH}\right]$, compound $\mathbf{7 1}$ gave the corresponding tin(II) hydride $\mathbf{7 6}$, that after hydrolysis led to tin(II) hydroxide 77 , seen as a $\mu$-hydroxido-bridged dimer in the solid state molecular structure. ${ }^{[54]}$

Tungsten complex was also obtained as non-symmetric distannyne from a tin(II) amide $\mathrm{L}^{\mathrm{I} S n N E t} t_{2}$ in reaction with $\left(2-\mathrm{Et}_{2} \mathrm{NCH}_{2}-4,6-t-\mathrm{Bu}_{2}-\mathrm{C}_{6} \mathrm{H}_{2}\right)(\mathrm{H}) \mathrm{Sn} \cdot \mathrm{W}(\mathrm{CO})_{5}$, through an amine elimination reaction. ${ }^{[55]}$

In the case of the chromium complex 70, first a tin(II) methoxide $\mathbf{7 2}$ was obtained in the presence of $\mathrm{NaOMe}$ which is then hydrolyzed to $\mu$-hydroxido-bridged dimer $\mathbf{7 3}$, as depicted in Scheme 11. ${ }^{[56]}$ Compound $\mathbf{7 3}$ in the presence of HOTf gave complex 74 (Scheme 11) where the formation of a cyclization product was observed through the deamination of the $\mathrm{Me}_{2} \mathrm{~N}-\mathrm{CH}_{2}-$ moiety and the formation of a new $\mathrm{C}-\mathrm{O}$ bond. ${ }^{[56]}$

The reactivity of the $\mathrm{L}^{\mathrm{II}} \mathrm{SnCl}$ stannylene $\mathbf{2 8}$, stabilized by the 2,6-bis[N-(2',6'-diisopropyl phenyl)ketimino]phenyl ligand with imino groups in ortho position of the central aromatic ring, was also tested towards various reactives. Stannylene $\mathbf{2 8}$ in reaction with $\mathrm{KC}_{8}$ formed bis-stannylene $\mathbf{7 8}$, containing a Sn-Sn bond, as shown in Scheme 12, with the tin atoms in +1 oxidation state. ${ }^{[31]}$ The solid state structure of $\mathbf{7 8}$ showed differences between the two tin atoms. Thus, one display a four-fold coordination, having interactions with both of the $\mathrm{N}$ atoms of the ortho substituents (2.6879(17) and $2.4129(16) \AA$ ) whereas the other binds to only one of the nitrogen atoms, with a distance of 2.2228(16) $\AA$, that is considerably shorter than the other Sn-N distances (Table 6). Bis-stannylene 78 activates $\mathrm{P}_{4}$, a selective cleavage of one P-P bond was observed, giving derivative $\mathbf{8 1}$, with a $\mathrm{P}_{4}$ tetrahedron inserted into the Sn-Sn bond and the two tin atoms symmetrically four-coordinated, as depicted in Scheme 12. ${ }^{[31]}$ 
Table 6. Chemical-physical data for N,C,N-pincer stabilized stannylene derivatives

\begin{tabular}{|c|c|c|c|c|c|c|c|c|}
\hline & $\begin{array}{c}C_{i p s o}-\mathrm{Sn} \\
\text { bond } \\
\text { length }(\AA)\end{array}$ & $\begin{array}{c}\text { Sn-R } \\
\text { bond } \\
\text { length }(\AA)\end{array}$ & $\begin{array}{l}\text { Sn-M bond } \\
\text { length }(\AA)\end{array}$ & $\begin{array}{c}\mathrm{N} \rightarrow \text { Sn } \\
\text { bond } \\
\text { length }(\AA)\end{array}$ & $\begin{array}{l}\mathrm{C}_{i p s o}-\text { Sn-R bond } \\
\text { angle }\left({ }^{\circ}\right)\end{array}$ & $\begin{array}{c}{ }^{13} \text { C NMR } \\
\text { S Cipso } \\
\text { (ppm) } \\
\text { (solvent) }\end{array}$ & $\begin{array}{l}{ }^{119} \text { Sn NMR } \\
\text { (ppm) } \\
\text { (solvent) }\end{array}$ & Ref \\
\hline 70 & $\begin{array}{l}\text { No RX } \\
\text { data }\end{array}$ & & & & & $\begin{array}{l}154.8 \\
\left(\mathrm{C}_{6} \mathrm{D}_{6}\right)\end{array}$ & $\begin{array}{l}327.4 \\
\left(\mathrm{C}_{6} \mathrm{D}_{6}\right)\end{array}$ & [56] \\
\hline 71 & $2.127(4)$ & $\begin{array}{l}\mathrm{R}=\mathrm{Cl} \\
2.4098(10)\end{array}$ & $\begin{array}{l}\mathrm{M}=\mathrm{W} \\
2.7630(3)\end{array}$ & $\begin{array}{l}2.543(3) \\
2.5526(3)\end{array}$ & $\begin{array}{l}\text { Cipso-Sn-Cl }-\mathrm{Cl} \\
103.89(10) \\
\text { Cipso-Sn-W }-\mathrm{S} \\
146.12(9)\end{array}$ & $\begin{array}{l}153.7 \\
\left(\mathrm{C}_{6} \mathrm{D}_{6}\right)\end{array}$ & $\begin{array}{l}140 \\
{ }^{1} \mathrm{~J}_{\mathrm{Sn}-\mathrm{W}}=1186 \mathrm{~Hz} \\
\left(\mathrm{C}_{6} \mathrm{D}_{6}\right)\end{array}$ & [53] \\
\hline 72 & $\begin{array}{l}\text { No RX } \\
\text { data }\end{array}$ & & & & & $\begin{array}{l}154.9 \\
\left(\mathrm{C}_{6} \mathrm{D}_{6}\right)\end{array}$ & $\begin{array}{l}301.1 \\
\left(\mathrm{C}_{6} \mathrm{D}_{6}\right)\end{array}$ & [56] \\
\hline 73 & $2.174(3)$ & $\begin{array}{l}\mathrm{R}=\mathrm{O} \\
2.064(2)\end{array}$ & $\begin{array}{l}\mathrm{M}=\mathrm{Cr} \\
2.618(1)\end{array}$ & $2.514(2)$ & $\begin{array}{l}\mathbf{C}_{\text {ipso }}-\mathrm{Sn}-\mathrm{O} \\
101.90(8) \\
\mathbf{C}_{\text {ipso }}-\mathrm{Sn}-\mathrm{Cr} 131.41\end{array}$ & $\begin{array}{l}149.7 \\
\left(\mathrm{CDCl}_{3}\right)\end{array}$ & $\begin{array}{l}331.9 \\
\left(\mathrm{CDCl}_{3}\right)\end{array}$ & [56] \\
\hline 74 & $2.111(4)$ & $\begin{array}{l}\mathrm{R}=\mathrm{O} \\
2.345(2)\end{array}$ & $\begin{array}{l}\mathrm{M}=\mathrm{Cr} \\
2.583(1)\end{array}$ & $2.468(3)$ & $\begin{array}{l}\text { Cipso }-\mathrm{Sn}-\mathrm{O} \\
74.50(1) \\
\text { Cipso-Sn-Cr }-\mathrm{Sr} \\
129.82(1)\end{array}$ & $\begin{array}{l}\text { Not } \\
\text { assigned }\end{array}$ & $\begin{array}{l}35.6 \\
\left(\mathrm{THF}-\mathrm{D}_{8}\right)\end{array}$ & [56] \\
\hline 75 & $2.150(3)$ & $\begin{array}{l}\mathrm{R}=\mathrm{O} \\
2.017(2)\end{array}$ & $\begin{array}{l}\mathrm{M}=\mathrm{W} \\
2.7117(33)\end{array}$ & $2.264(2)$ & $\begin{array}{l}\text { Cipso-Sn-O }-\mathrm{O}(10) \\
90.25(10) \\
\text { Cipso-Sn-W } \\
135.95(8)\end{array}$ & $\begin{array}{l}144.1 \\
\left(\mathrm{THF}-\mathrm{D}_{8}\right)\end{array}$ & $\begin{array}{l}-8.4 \\
\left(\mathrm{THF}-\mathrm{D}_{8}\right)\end{array}$ & [53] \\
\hline 76 & $\begin{array}{l}\text { No RX } \\
\text { data }\end{array}$ & & & & & $\begin{array}{l}150.4 \\
\left(\mathrm{C}_{6} \mathrm{D}_{6}\right)\end{array}$ & $\begin{array}{l}199.0 \\
{ }^{1} \mathrm{~J}_{\mathrm{W}-\mathrm{Sn}}=870 \mathrm{~Hz} \\
\left(\mathrm{C}_{6} \mathrm{D}_{6}\right)\end{array}$ & [54] \\
\hline 77 & $2.176(7)$ & $\begin{array}{l}\mathrm{R}=\mathrm{OH} \\
2.068(5)\end{array}$ & $\begin{array}{l}\mathrm{M}=\mathrm{W} \\
2.7644(6)\end{array}$ & $2.501(7)$ & $\begin{array}{l}\text { Cipso-Sn-O }-\mathrm{Sn}(2) \\
102.1(2) \\
\text { Cipso }_{\text {-Sn-W }} \\
130.3(2)\end{array}$ & $\begin{array}{l}154.9 \\
\left(\mathrm{CDCl}_{3}\right)\end{array}$ & $\begin{array}{l}79 \\
\left(\mathrm{CDCl}_{3}\right)\end{array}$ & [54] \\
\hline 78 & $2.1575(18)$ & $\begin{array}{l}\text { Sn-Sn } \\
2.8981(9)\end{array}$ & - & $\begin{array}{l}2.6879(17) \\
2.4129(16) \\
2.2228(16)\end{array}$ & $\begin{array}{l}\text { Cipso-Sn-Sn } \\
96.63(5)\end{array}$ & $\begin{array}{l}186.32 \\
\left(\mathrm{C}_{6} \mathrm{D}_{6}\right)\end{array}$ & Not seen & [31] \\
\hline 79 & $2.146(3)$ & $\begin{array}{l}\text { Sn-Sn } \\
2.9250(5)\end{array}$ & & $\begin{array}{l}2.482(3) \\
2.526(3) \\
2.492(3) \\
2.613(3)\end{array}$ & $\begin{array}{l}\text { Cipso-Sn-Sn }_{108.27(9)} \\
108.20\end{array}$ & No data & $\begin{array}{l}118 \\
\left(\mathrm{C}_{6} \mathrm{D}_{6}\right)\end{array}$ & [32] \\
\hline 80 & $2.148(4)$ & $\begin{array}{l}\text { Sn-Sn } \\
2.9491(4)\end{array}$ & - & $\begin{array}{l}2.482(4) \\
2.636(4)\end{array}$ & $\begin{array}{l}C_{\text {ipso-Sn-Sn }} \text {-S6-12) } \\
101.26(12)\end{array}$ & $\begin{array}{l}\text { Not } \\
\text { assigned }\end{array}$ & $\begin{array}{l}79 \\
\mathrm{~J}_{\text {Sn-Sn }}=4156 \mathrm{~Hz} \\
\text { THF-D } 8\end{array}$ & [33] \\
\hline 81 & $\begin{array}{l}2.165 \\
2.172\end{array}$ & $\begin{array}{l}\mathrm{R}=\mathrm{P} \\
2.7189(9)\end{array}$ & - & $\begin{array}{l}2.471(2) \\
2.492(2) \\
2.519(2) \\
2.456(3)\end{array}$ & $\begin{array}{l}\text { Cipso-Sn-P }_{87} \\
87.61 \\
104.48(9)\end{array}$ & $\begin{array}{l}182.34 \\
\left(\mathrm{C}_{6} \mathrm{D}_{6}\right)\end{array}$ & $\begin{array}{l}703.33 \\
\left(\mathrm{C}_{6} \mathrm{D}_{6}\right)\end{array}$ & [31] \\
\hline 82 & $2.114(4)$ & $\begin{array}{l}\text { Sn-K } \\
3.6144(8)\end{array}$ & - & $2.268(3)$ & & $\begin{array}{l}\text { Not } \\
\text { assigned }\end{array}$ & $\begin{array}{l}310 \\
\left(\mathrm{THF}-\mathrm{D}_{8}\right)\end{array}$ & [33] \\
\hline 83 & $2.1665(16)$ & $\begin{array}{l}\mathrm{R}=\mathrm{H} \\
\text { Calculated } \\
\text { Ge-H } \\
1.787- \\
1.792\end{array}$ & - & $\begin{array}{l}2.4538(13) \\
2.4664(14)\end{array}$ & & $\begin{array}{l}182.34 \\
\left(\mathrm{C}_{6} \mathrm{D}_{6}\right)\end{array}$ & $\begin{array}{l}-114.27 \\
{ }^{1} \mathrm{~J}_{\mathrm{Sn}-\mathrm{H}}=112.9 \mathrm{~Hz} \\
\left(\mathrm{C}_{6} \mathrm{D}_{6}\right)\end{array}$ & [20] \\
\hline 84 & $2.126(7)$ & $\begin{array}{l}\mathrm{R}=\mathrm{Cl} \\
2.440(15)\end{array}$ & $\begin{array}{l}\mathrm{M}=\mathrm{W} \\
2.732(5)\end{array}$ & $\begin{array}{l}2.391(5) \\
2.389(5)\end{array}$ & $\begin{array}{l}C_{i p s o}-\mathrm{Sn}-\mathrm{W} \\
144.19(16) \\
\text { Cipso }_{\text {ipn-Cl }}-\mathrm{Cl} \\
99.63(17)\end{array}$ & Not found & $\begin{array}{l}197 \\
{ }^{19} \mathrm{~J}_{\mathrm{Sn}-\mathrm{W}}=1245 \\
\mathrm{~Hz} \\
\left(\mathrm{C}_{6} \mathrm{D}_{6}\right)\end{array}$ & {$[57]$} \\
\hline 85 & $2.129(3)$ & $\begin{array}{l}\mathrm{R}=\mathrm{Cl} \\
2.382(11)\end{array}$ & $\begin{array}{l}\mathrm{M}=\mathrm{W} \\
2.7655(4)\end{array}$ & $\begin{array}{l}2.464(3) \\
2.513(3)\end{array}$ & $\begin{array}{l}\mathbf{C}_{i p s o}-\mathrm{Sn}-\mathrm{W} \\
130.03(10) \\
\mathbf{C}_{i p s o}-\mathrm{Sn}-\mathrm{Cl} \\
104.45(10)\end{array}$ & 151.9 & $\begin{array}{l}257 \\
{ }^{1} \mathrm{~J}_{\mathrm{Sn}-\mathrm{W}}=1289 \\
\mathrm{~Hz} \\
\left(\mathrm{C}_{6} \mathrm{D}_{6}\right)\end{array}$ & {$[57]$} \\
\hline 86 & $\begin{array}{l}\text { No RX } \\
\text { data }\end{array}$ & & & & & 145.9 & $\begin{array}{l}299 \\
{ }^{1} \mathrm{~J}_{\mathrm{Sn}-\mathrm{W}}=1242\end{array}$ & [57] \\
\hline
\end{tabular}




\begin{tabular}{|c|c|c|c|c|c|c|c|c|}
\hline & & & & & & & $\begin{array}{l}\mathrm{Hz} \\
\left(\mathrm{C}_{6} \mathrm{D}_{6}\right)\end{array}$ & \\
\hline 87 & $2.129(4)$ & $\begin{array}{l}\mathrm{R}=\mathrm{Cl} \\
2.3936(12)\end{array}$ & $\begin{array}{l}\mathrm{M}=\mathrm{Cr} \\
2.5809(8)\end{array}$ & $\begin{array}{l}2.393(3) \\
2.407(3)\end{array}$ & $\begin{array}{l}\text { Cipso }_{\text {ipn-Cr }}-\mathrm{Cr} \\
146.06(11) \\
\text { Cipso-Sn-Cl }_{1}-\mathrm{Sn}-\mathrm{C} \\
104.45(10) \\
99.93(11)\end{array}$ & 151.0 & $\begin{array}{l}396.3 \\
\left(\mathrm{C}_{6} \mathrm{D}_{6}\right)\end{array}$ & [58] \\
\hline 88 & $2.109(4)$ & $\begin{array}{l}\mathrm{R}=\mathrm{O} \\
2.118(4)\end{array}$ & $\begin{array}{l}\mathrm{M}=\mathrm{Cr} \\
2.5598(7)\end{array}$ & $\begin{array}{l}2.331(3) \\
2.401(3)\end{array}$ & $\begin{array}{l}\mathbf{C}_{i p s o}-\mathrm{Sn}-\mathrm{Cr} \\
151.72(11) \\
\mathbf{C}_{i p s s}-\mathrm{Sn}-\mathrm{O} \\
96.34(15)\end{array}$ & 149.8 & $\begin{array}{l}224 \\
\left(\mathrm{THF}-\mathrm{D}_{8}\right)\end{array}$ & [58] \\
\hline 89 & $2.102(13)$ & $\begin{array}{l}\mathrm{R}=\mathrm{O} \\
2.435(8) \\
2.431(7)\end{array}$ & $\begin{array}{l}\mathrm{M}=\mathrm{Cr} \\
2.561(2)\end{array}$ & $2.376(5)$ & $\begin{array}{l}\mathbf{C}_{i p s o}-\mathrm{Sn}-\mathrm{Cr} \\
177.7(3) \\
\mathbf{C}_{i p s o}-\mathrm{Sn}-\mathrm{O} \\
81.5(4)\end{array}$ & 149.7 & $\begin{array}{l}249.9 \\
\left(\mathrm{THF}-\mathrm{D}_{8}\right)\end{array}$ & [58] \\
\hline
\end{tabular}

Similarly to germylene $\mathbf{3}$, the tin analogue $\mathbf{2 8}$ formed the corresponding hydride $\mathbf{8 3}$ in the presence of K-selectride, as shown in Scheme 12. The solid state structure showed that the tin atom is four-coordinated, with the Sn-N interactions of 2.4538(3) and 2.4664(14) $\AA .{ }^{[20]}$

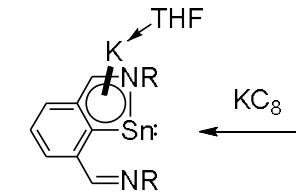

$\mathrm{R}=t-\mathrm{Bu}, \mathrm{R}^{\prime}=\mathrm{H}, 82$<smiles>[R][R17]1nc([R])c2cccc(C([R])=[NH2+])c12</smiles>

个 $\mathrm{R}=2,6-i-\mathrm{Pr}_{2} \mathrm{C}_{6} \mathrm{H}_{3}, \mathrm{R}^{\prime}=\mathrm{Me}, 78$ $\begin{array}{ll}\mathrm{KC}_{8} \quad 2,6-\mathrm{Me}_{2}-\mathrm{C}_{6} \mathrm{H}_{3} \mathrm{R}^{\prime}=\mathrm{H}, & 79 \\ \mathrm{~T} & \end{array}$ THF $t$-Bu, $\mathrm{R}^{\prime}=\mathrm{H}$,

$\mathrm{P}_{4} /$ toluene

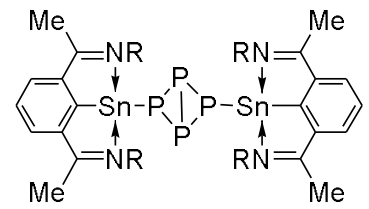

$\mathrm{R}=2,6-\mathrm{iPr}_{2} \mathrm{C}_{6} \mathrm{H}_{3}, \mathrm{R}^{\prime}=\mathrm{Me}, 81$
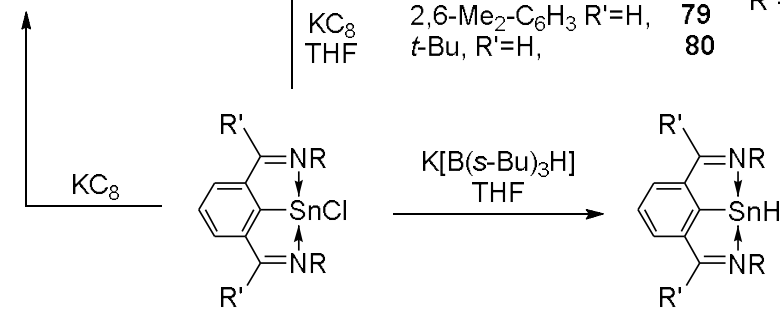

$\mathrm{R}=2,6-i-\mathrm{Pr}_{2} \mathrm{C}_{6} \mathrm{H}_{3}, \mathrm{R}^{\prime}=\mathrm{Me}, \quad 28$ $2,6-\mathrm{Me}_{2}-\mathrm{C}_{6} \mathrm{H}_{3} \mathrm{R}^{\prime}=\mathrm{H}, \quad 29$ $t$-Bu R'=H

$\mathrm{R}=2,6-i-\mathrm{Pr}_{2} \mathrm{C}_{6} \mathrm{H}_{3}, \mathrm{R}^{\prime}=\mathrm{Me}, 83$ 30

Scheme 12. Synthesis and reactivity of imino-N,C,N-pincer stabilized stannylene 
Using 2,6-dimethylphenyl and tert-butyl as substituents on the ortho-imino groups of the 2,6bis(imino)phenyl ligand, chlorostannylenes $\mathbf{2 9}$ and $\mathbf{3 0}$ were obtained and characterized. In the case of the stannylene 30, the X-ray analysis revealed Sn-N distances of 2.507(2) and of 2.597(2) $\AA$, similar to other Sn-N interaction, however the Sn-Cl bond of 2.5624(5) Å was observed to be slightly longer than in other chlorostannylenes. ${ }^{[33]}$ In the presence of $\mathrm{KC}_{8}$, in both cases, a distannyne was obtained and characterized. The solid state structures showed Sn-Sn bond lengths of 2.9250(5) $\AA$ (79), $2.9491(4) \AA$ (80), indicating Sn-Sn single bond, whereas the Sn-N interactions are comparable to intramolecular Sn-N coordinations. ${ }^{[32,33]}$ The reaction of distannyne $\mathbf{8 0}$ with an excess of $\mathrm{KC}_{8}$ led to the cleavage of the tin-tin bond and formed potassium stannylidenide $\mathbf{8 2}$. The $\mathrm{K}$ atom is coordinated with a THF molecule and is $\eta^{5}$-coordinated to the SnCCCN five-membered ring, where an electron delocalization is suggested to stabilize the negative charge on the tin atom. ${ }^{[33]}$

Using an O,C,O-type pincer ligand, where the ortho substituents on the aromatic ring are Odonor ether groups, stannylenes $\mathbf{3 1}$ and $\mathbf{3 2}$ were synthesized, as illustrated in Scheme $8 .{ }^{[57,59]}$ Both stannylenes were characterized by NMR spectroscopy and mass spectrometry, exhibiting the characteristics for a pincer stabilized chlorostannylene. ${ }^{[57]}$

By adding $\mathrm{W}(\mathrm{CO})_{5} \mathrm{SnCl}_{2}$ to $\left[2,6-\left(\mathrm{ROCH}_{2}\right)_{2} \mathrm{C}_{6} \mathrm{H}_{3}\right] \mathrm{Li} \quad(\mathrm{R}=\mathrm{Me}, t-\mathrm{Bu})$, stannylene pentacarbonyl-tungsten complexes $\mathbf{8 4}$ and $\mathbf{8 5}$ were obtained, as presented in Scheme 13. ${ }^{[57]}$

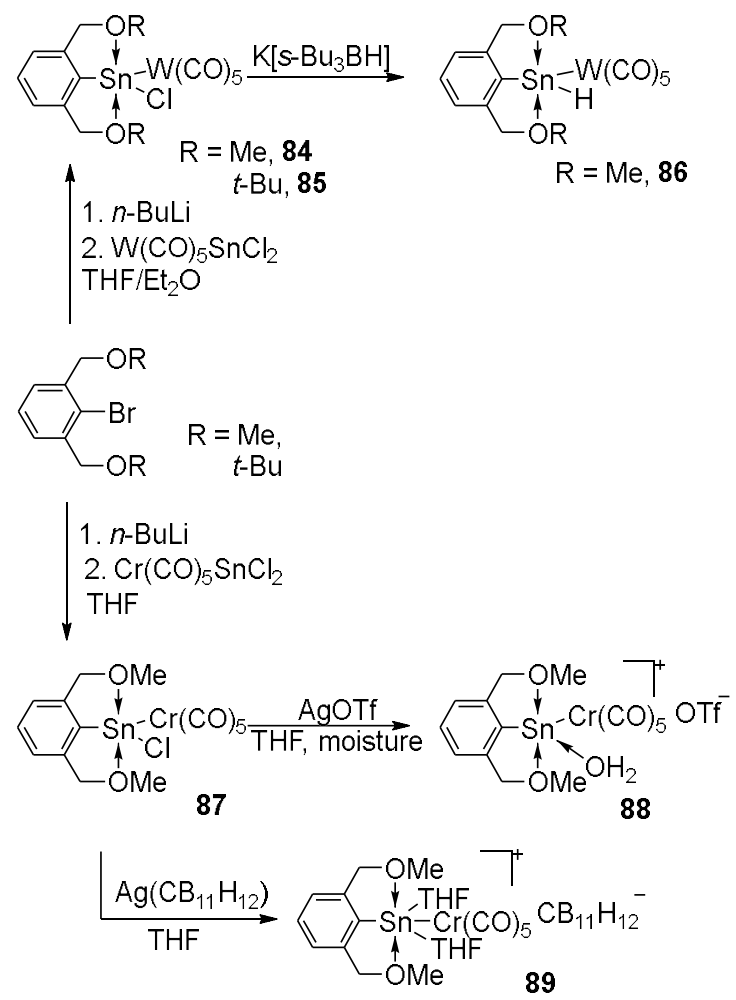

Scheme 13. Synthesis of O,C,O-pincer stabilized stannylene and stannylene-tungsten complex stannylene-chromium complex 
The solid state structures of $\mathbf{8 4}$ and $\mathbf{8 5}$ showed that the Sn-O interactions in the methylsubstituted complex are of 2.391(5) and 2.389(5) $\AA$, while in the tert-butyl substituted one 2.464(3) and 2.513(3) $\AA$. The Sn-Cl bond length in the methyl-substituted complex is 2.440(15) $\AA$ and in the tert-butyl substituted complex is $2.382(11) \AA$. These values, along with the data gained from the NMR spectroscopy suggest that the $\mathrm{O} \rightarrow$ Sn coordination is influenced by the substituents on the oxygen atom in the ortho-substituents of the aromatic ring in the pincer ligand, stronger in the methyl substituted complex than in the tert-butyl substituted one. The interactions increase the stability of the complexes, so that the methyl-substituted stannylene-tungsten complex 84 is stable at exposure to air. The reaction of this complex with $\mathrm{K}\left[s-\mathrm{Bu} \mathrm{u}_{3} \mathrm{BH}\right]$ results in the corresponding stannylene-tungsten hydride 86 (Scheme 13). The NMR spectroscopy indicates the characteristic signals for such compounds. ${ }^{[57]}$

In a similar manner, chromium complex $\mathbf{8 8}$ was also obtained (Scheme 13). [46] $\mathrm{Cr}(\mathrm{CO})_{5} \mathrm{SnCl}_{2} \cdot \mathrm{THF}$ was added to $\left[2,6-\left(\mathrm{MeOCH}_{2}\right)_{2} \mathrm{C}_{6} \mathrm{H}_{3}\right] \mathrm{Li}$ to form stannylenepentacarbonylchromium complex 87. The structure of the complex is similar to that with tungsten (Scheme 13), the Sn-O distances are of 2.393(3) and 2.409(3) $\AA$, suggesting strong interactions. Starting from the chlorostannylene chromium complex $\mathbf{8 7}$, an organostannylidenium trifluorosulfonate aqua complex $\mathbf{8 8}$ was formed in the presence of AgOTf, while with $\mathrm{Ag}\left[\mathrm{CB}_{11} \mathrm{H}_{12}\right]$ the stannylidenium carbaborate $\mathbf{8 9}$ was obtained. ${ }^{[58]}$

The stannylenes were also obtained starting from monoanionic $\mathrm{O}, \mathrm{C}, \mathrm{O}-\mathrm{chelating}$ pincer type ligand, the 4-t-Bu-2,6-[P(O)(OR $\left.)_{2}\right]_{2}-\mathrm{C}_{6} \mathrm{H}_{2}, \mathrm{~L}^{\mathrm{IV}}$, with phosphonate groups in ortho positions of the aromatic ring. Stannylenes 33-37 were obtained by adding LDA to the 1,3-bis(dialkylphosphonyl)-5$t$-butylbenzene, followed by $\mathrm{SnX}_{2}, \mathrm{SnBr}_{2}$, or $\mathrm{SnI}_{2}$. (Scheme 8) ( $^{[34,35,60]}$

The reactivity of these stannylenes was tested in reaction with a large number of compounds, obtaining a series of new derivatives, as shown in Scheme 14.

Stannylene 33 reacted with lithium derivatives to give new divalent tin compounds 9093. ${ }^{[34,35]}$ 


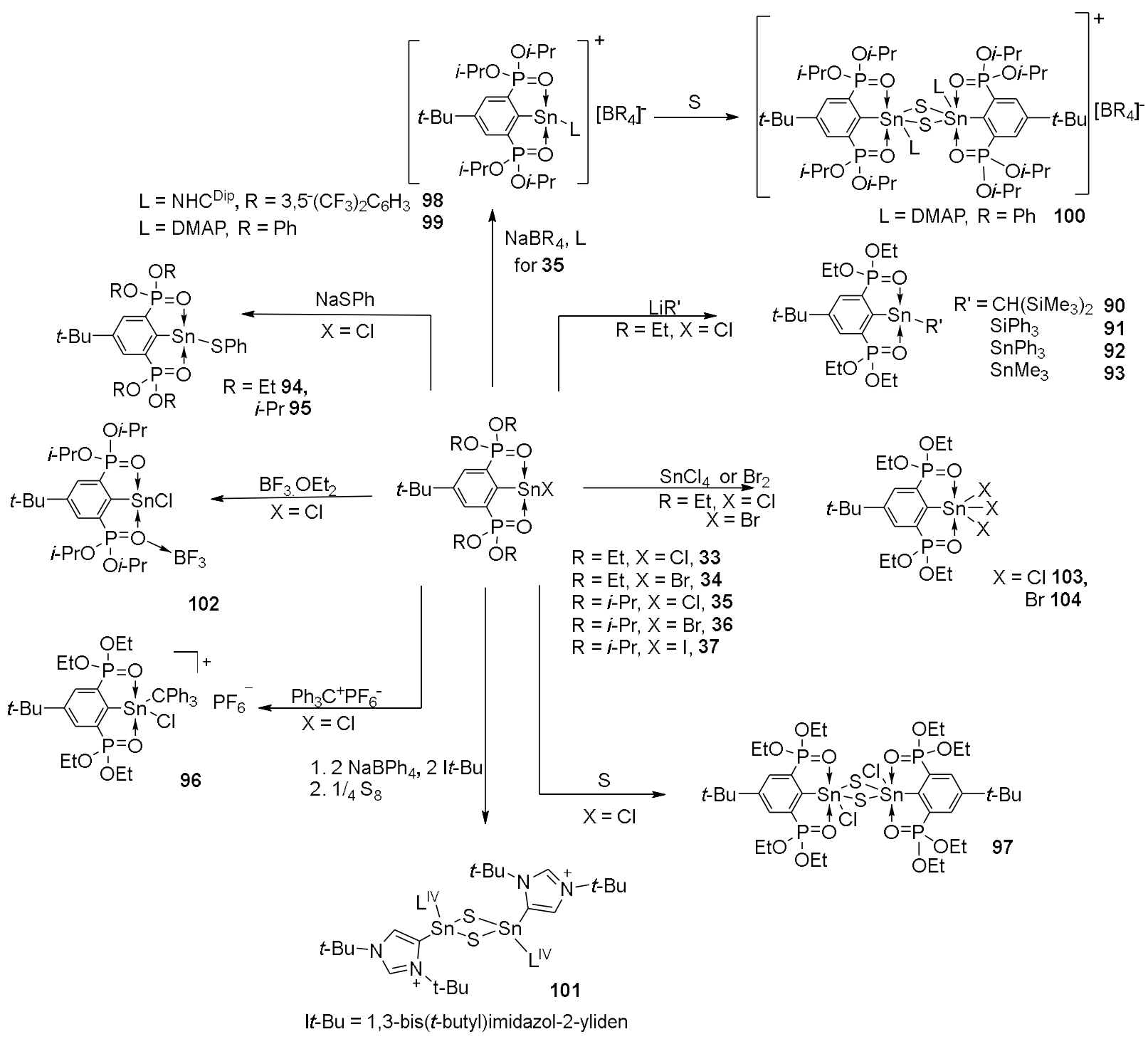

Scheme 14. Reactivity of the O,C,O-pincer stabilized stannylenes

Oxidative addition at stannylenes $\mathbf{3 3}$ and $\mathbf{3 4}$ was achieved by adding sulphur, bromine or $\mathrm{Ph}_{3} \mathrm{C}^{+} \mathrm{PF}_{6}^{-}$, giving tetravalent tin derivatives 97, 104 and diorganotin cation 96, as shown in Scheme 14. ${ }^{[34]}$ By adding $\mathrm{SnCl}_{4}$ to chlorostannylene 33, a redox process took place to form trichlorotin derivative 103, where the tin atom is hexacoordinated. ${ }^{[61]}$ The ${ }^{119} \mathrm{Sn}$ chemical shift at $-528.8 \mathrm{ppm}$ (see Table 7) for compound $\mathbf{1 0 3}$ suggests the high donor capacity of the O,C,O-pincer ligand, with strong Sn-O interactions and the X-ray analysis shows the Sn-O interactions of 2.225(3) and 2.221(3) $\AA$. ${ }^{[61]}$

Tin(II) containing cations of stannylene 35 were obtained being stabilized by intermolecular coordination of the Lewis bases of the type 1,3-bis(2,6-diisopropylphenyl)imidazol-2-ylidene $\left(\mathrm{NHC}^{\mathrm{Dip}}\right)$ or 4-dimethylaminopyridine (DMAP), as shown in Scheme $14 .{ }^{[62]}$ The structural features of the products 98 and 99 exhibit some steric constraints and a high $s$ character of the lone pair of electrons on the tin atoms. In the ${ }^{119}$ Sn NMR spectra of compounds 98 and $\mathbf{9 9}$, the triplet signals at 169 and $-170 \mathrm{ppm}$, respectively, showed the similar electronic environment of the tin atoms. The 
tin(II)-DMAP adduct 99 in reaction with elemental sulphur gave dimeric derivative 100, bridging sulphur atoms linking the two stannylene monomers. ${ }^{[62]}$ (Scheme 14) A similar dimeric species, the a NHC-stabilized organotin(IV) sulphide dication 101, was formed through the reaction of stannylene 35 with $\mathrm{NaBPh}_{4}$ and 1,3-bis(tert-butyl)imidazol-2-yliden (It-Bu) and subsequent treatment of the reaction mixture with elemental sulphur. ${ }^{[63]}$

Reaction of stannylene 35 with $\mathrm{BF}_{3} \cdot \mathrm{OEt}_{2}$ gave adduct 102 with an $\mathrm{O} \rightarrow \mathrm{BF}_{3}$ interaction (Scheme 14). ${ }^{[63]}$ Structural analyses carried out on 102 showed very different Sn-O coordinations, with the bond lengths of 2.222(2) and of 2.7477(18) $\AA$, as a result of the $\mathrm{O}-\mathrm{BF}_{3}$ coordination. The ${ }^{119} \mathrm{Sn}$ NMR exhibits two signals (-25 and $-100 \mathrm{ppm}$ ), explained by an equilibrium between the stannylene and its adduct with $\mathrm{BF}_{3}{ }^{[63]}$

Transition metal complexes were also obtained starting from the O,C,O-pincer stabilized stannylenes $\mathbf{3 4}$ and 35, forming tungsten, chromium and iron complexes, as shown in Scheme 15. ${ }^{[34,35,64]}$ The ${ }^{119} \mathrm{Sn}$ NMR spectra showed shifts for the signals of the complexes ranging from -74 to 131 ppm for complexes 105-107, compared to $-68 \mathrm{ppm}$ for stannylene $34(\mathrm{R}=\mathrm{Et}){ }^{[34]}$ In the case of complexes 108-113 and 115-116 the chemical shifts in the ${ }^{119} \mathrm{Sn}$ NMR can be observed between -75 and 127.9 ppm, downfield shifted compared to stannylene 35 (-99 ppm). ${ }^{[35,64,65]}$ In the case of complex 114, where a fluorine atom is linked to the tin atom, the signal in the ${ }^{119} \mathrm{Sn}$ NMR appeared upfield shifted compared to stannylene 35 . ${ }^{[64]}$

The solid state structures of compounds 105 - 109 showed that Sn-O bond lengths range inbetween 2.313(2) and 2.354(2) $\AA$, suggesting stronger interactions than in the starting stannylenes. ${ }^{[34,35,64]}$ 
Table 7. Chemical-physical data for $\mathrm{O}, \mathrm{C}, \mathrm{O}-$ pincer stabilized $\mathrm{L}^{\mathrm{IV}} \mathrm{SnCl}$ stannylene derivatives

\begin{tabular}{|c|c|c|c|c|c|c|c|c|}
\hline & $\begin{array}{c}\mathrm{C}_{i p s o}-\mathrm{Sn} \\
\text { bond } \\
\text { length }(\AA)\end{array}$ & $\begin{array}{l}\text { Sn-R bond } \\
\text { length }(\AA)\end{array}$ & $\begin{array}{c}\text { Sn-M } \\
\text { bond } \\
\text { length }(\AA)\end{array}$ & $\begin{array}{c}\mathrm{O} \rightarrow \mathrm{Sn} \\
\text { bond } \\
\text { length }(\AA)\end{array}$ & $\begin{array}{l}\text { Cipso-Sn-R } \\
\text { bond } \\
\text { angle }\left({ }^{\circ}\right)\end{array}$ & $\begin{array}{c}{ }^{13} \mathrm{C} \mathrm{NMR} \\
\delta \mathrm{C}_{i p s o}(\mathrm{ppm}) \\
\text { (solvent) }\end{array}$ & $\begin{array}{c}{ }^{119} \text { Sn NMR } \\
\text { (ppm) } \\
\text { (solvent) }\end{array}$ & Ref \\
\hline 90 & No RX data & & & & & $\begin{array}{l}189.8, \mathrm{t} \\
{ }^{2} \mathrm{~J}_{\mathrm{C}-\mathrm{P}}=37 \mathrm{~Hz} \\
\left(\mathrm{Tol}-\mathrm{D}_{8}\right)\end{array}$ & $\begin{array}{l}259, \mathrm{t} \\
\mathrm{J}_{\mathrm{P}-\mathrm{Sn}}=106 \mathrm{~Hz}\end{array}$ & {$[34]$} \\
\hline 91 & $2.228(3)$ & $\begin{array}{l}\mathrm{R}=\mathrm{Si} \\
2.751(1)\end{array}$ & - & $\begin{array}{l}2.543(3) \\
2.446(2)\end{array}$ & $96.35(9)$ & $\begin{array}{l}185.5, \mathrm{t}, \\
{ }^{2} \mathrm{~J}_{\mathrm{C}-\mathrm{P}}=36 \mathrm{~Hz} \\
\left(\mathrm{THF}-\mathrm{D}_{8} / \mathrm{D}_{2} \mathrm{O}-\right. \\
\text { cap) }\end{array}$ & $\begin{array}{l}192, \mathrm{t} \\
\mathrm{J}_{\mathrm{P}-\mathrm{Sn}}=96 \mathrm{~Hz}\end{array}$ & [34] \\
\hline 92 & No RX data & & & & & No data & $\begin{array}{l}109, \mathrm{t} \\
\mathrm{J}_{\mathrm{Sn}-\mathrm{P}}=98 \mathrm{~Hz} \\
\mathrm{~J}_{\mathrm{Sn}-\mathrm{Sn}}= \\
9130 / 9550 \mathrm{~Hz} \\
\text { (THF-D } / \mathrm{D}_{2} \mathrm{O}- \\
\text { cap.) }\end{array}$ & {$[34]$} \\
\hline 93 & No RX data & & & & & No data & $\begin{array}{l}217, \mathrm{t} \\
\mathrm{J}_{\mathrm{Sn}-\mathrm{P}}=93 \mathrm{~Hz} \\
\mathrm{~J}_{\mathrm{Sn}-\mathrm{Sn}}= \\
7976 / 8346 \mathrm{~Hz} \\
\left(\mathrm{THF}-\mathrm{D}_{8} / \mathrm{D}_{2} \mathrm{O}-\right. \\
\text { cap. })\end{array}$ & {$[34]$} \\
\hline 94 & No RX data & & & & & $\begin{array}{l}182.7, \mathrm{t} \\
{ }^{3} \mathrm{~J}_{\mathrm{C}-\mathrm{P}}=35 \mathrm{~Hz} \\
\left(\mathrm{CDCl}_{3}\right)\end{array}$ & $\begin{array}{l}2, \mathrm{t} \\
\mathrm{J}_{\mathrm{Sn}-\mathrm{P}}=96 \mathrm{~Hz} \\
\left(\mathrm{Tol}-\mathrm{D}_{8} / \mathrm{D}_{2} \mathrm{O}-\right. \\
\text { cap.) }\end{array}$ & [34] \\
\hline 95 & $2.231(3)$ & $\begin{array}{l}\mathrm{R}=\mathrm{S} \\
2.512(1)\end{array}$ & - & $\begin{array}{l}2.478(2) \\
2.434(2)\end{array}$ & $89.38(8)$ & $\begin{array}{l}182.9, \mathrm{t} \\
{ }^{2} \mathrm{~J}_{\mathrm{C}-\mathrm{P}}=35.2 \mathrm{~Hz} \\
\left(\mathrm{Tol}_{-} \mathrm{D}_{8}\right)\end{array}$ & 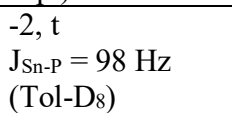 & {$[35]$} \\
\hline 96 & $2.149(4)$ & $\begin{array}{l}\mathrm{R} 1=\mathrm{Cl}, 2.504 \\
\mathrm{R} 2=\mathrm{S} \\
2.357(1)\end{array}$ & - & $\begin{array}{l}2.260(3) \\
2.267(3)\end{array}$ & $\begin{array}{l}\mathbf{C}_{i p s o}-\mathrm{Sn}- \\
\mathrm{Cl} 87.8(1) \\
\text { C }_{i p s o}-\mathrm{Sn}-\mathrm{S} \\
179.0(1)\end{array}$ & $\begin{array}{l}156.3, \mathrm{t} \\
{ }^{2} \mathrm{~J}_{\mathrm{C}-\mathrm{P}}=16 \mathrm{~Hz} \\
\left(\text { acetone- } \mathrm{D}_{6}\right)\end{array}$ & $\begin{array}{l}-322, \mathrm{t} \\
\mathrm{J}_{\mathrm{Sn}-\mathrm{P}}=52 \mathrm{~Hz} \\
\left(\text { acetone- } \mathrm{D}_{6} \text { ) }\right.\end{array}$ & [34] \\
\hline 97 & No RX data & $\begin{array}{l}\mathrm{R}=\mathrm{S} \\
2.357(1)\end{array}$ & & $\begin{array}{l}2.260(3) ; \\
2.267(3)\end{array}$ & $\begin{array}{l}\mathbf{C}_{i p s o}-\mathrm{Sn}-\mathrm{S} \\
179.0(1) \\
\mathbf{C}_{i p s o}-\mathrm{Sn}- \\
\mathrm{Cl} \\
93.1(1)\end{array}$ & $\begin{array}{l}177.5 \mathrm{t}, \\
{ }^{2} J_{\mathrm{C}-\mathrm{P}}=19 \mathrm{~Hz} \\
\left(\mathrm{THF}-\mathrm{D}_{8}\right)\end{array}$ & $\begin{array}{l}-439 \mathrm{t}, \\
\mathrm{J}_{\text {Sn-P }}=84 \mathrm{~Hz} \\
\left(\mathrm{THF}-\mathrm{D}_{8}\right)\end{array}$ & [34] \\
\hline 98 & $2.202(4)$ & $\begin{array}{l}\mathrm{R}=\mathrm{C} \\
2.287(4)\end{array}$ & - & $\begin{array}{l}2.423(3) \\
2.360(2)\end{array}$ & $101.2(1)$ & $\begin{array}{l}177.6, \mathrm{t},{ }^{3} \mathrm{~J}_{\mathrm{C}-\mathrm{P}}= \\
33 \mathrm{~Hz} \\
\left(\mathrm{CD}_{2} \mathrm{Cl}_{2}\right)\end{array}$ & $\begin{array}{l}-169, \mathrm{t}, \mathrm{J}_{\mathrm{Sn}-\mathrm{P}}= \\
142 \mathrm{~Hz} \\
\left(\mathrm{CD}_{2} \mathrm{Cl}_{2}\right)\end{array}$ & {$[62]$} \\
\hline 99 & $2.234(2)$ & $\begin{array}{l}\mathrm{R}=\mathrm{N} \\
2.243(2)\end{array}$ & - & $\begin{array}{l}2.407(2) \\
2.482(2)\end{array}$ & $91.73(8)$ & $\begin{array}{l}180.4, \mathrm{t} \\
{ }^{3} \mathrm{~J}_{\mathrm{C}-\mathrm{P}}=34 \mathrm{~Hz} \\
\left(\mathrm{CD}_{2} \mathrm{Cl}_{2}\right)\end{array}$ & $\begin{array}{l}-170, \mathrm{t} \\
\mathrm{J}_{\mathrm{Sn}-\mathrm{P}}=135 \mathrm{~Hz} \\
\left(\mathrm{CD}_{2} \mathrm{Cl}_{2}\right)\end{array}$ & [62] \\
\hline 100 & $2.143(2)$ & $\begin{array}{l}\mathrm{R}=\mathrm{N} \\
2.297(2) \\
\mathrm{R}=\mathrm{S} \\
2.3472(5) \\
2.5515(5)\end{array}$ & - & $\begin{array}{l}2.25(1) \\
2.227(1)\end{array}$ & $\begin{array}{l}\mathbf{C}_{i p s o}-\mathrm{Sn}-\mathrm{N} \\
91.19(6)\end{array}$ & $\begin{array}{l}168.2, \mathrm{t} \\
{ }^{3} \mathrm{~J}_{\mathrm{C}-\mathrm{P}}=19 \mathrm{~Hz} \\
\left(\mathrm{CD}_{2} \mathrm{Cl}_{2}\right)\end{array}$ & $\begin{array}{l}-423, \mathrm{t}, \mathrm{J}_{\mathrm{Sn}-\mathrm{P}}= \\
108 \mathrm{~Hz} \\
\mathrm{~J}_{\mathrm{Sn}-\mathrm{Sn}}=341 \mathrm{~Hz} \\
\left(\mathrm{CD}_{2} \mathrm{Cl}_{2}\right)\end{array}$ & {$[62]$} \\
\hline 101 & $2.1698(19)$ & $\begin{array}{l}\mathrm{R}=\mathrm{C}(\mathrm{NHC}) \\
2.1555(19) \\
\mathrm{R}=\mathrm{S} \\
2.4357(5) \\
2.4181(5)\end{array}$ & - & $\begin{array}{l}2.7977(13) \\
2.5554(13)\end{array}$ & $\begin{array}{l}\mathbf{C}_{i p s o}-\mathrm{Sn}-\mathrm{S} \\
107.24(5) \\
119.62(5)\end{array}$ & $\begin{array}{l}157.4, \mathrm{t} \\
{ }^{2} \mathrm{~J}_{\mathrm{C}-\mathrm{P}}=18.5 \mathrm{~Hz} \\
\left(\mathrm{CD}_{3} \mathrm{CN}\right)\end{array}$ & $\begin{array}{l}-225, \mathrm{t}, \mathrm{J}_{\mathrm{Sn}-\mathrm{P}}=60 \\
\mathrm{~Hz} \\
\mathrm{~J}_{\mathrm{Sn}-\mathrm{Sn}}=287 \mathrm{~Hz} \\
\left(\mathrm{CD}_{3} \mathrm{CN}\right)\end{array}$ & {$[66]$} \\
\hline 102 & $2.245(3)$ & $\begin{array}{l}\mathrm{R}=\mathrm{Cl} \\
2.4620(8)\end{array}$ & - & $\begin{array}{l}2.222(2) \\
2.7477(18)\end{array}$ & $86.84(7)$ & No data & $\begin{array}{l}-25, \mathrm{~s} ;-110, \mathrm{~s} \\
\left(\mathrm{C}_{6} \mathrm{D}_{6}\right)\end{array}$ & [63] \\
\hline 103 & $2.132(4)$ & $\begin{array}{l}\mathrm{R}=\mathrm{Cl} \\
2.332(1) \\
\mathrm{R} 2=\mathrm{Cl} \\
2.434(1) \\
\mathrm{R} 3=\mathrm{Cl} \\
4.422(1)\end{array}$ & - & $\begin{array}{l}2.225(3) \\
2.221(2)\end{array}$ & $\begin{array}{l}177.8(1) \\
90.91(1) \\
91.8(1)\end{array}$ & $\begin{array}{l}173.1, \mathrm{t} \\
{ }^{2} \mathrm{~J}_{\mathrm{C}-\mathrm{P}}=17 \mathrm{~Hz} \\
\left(\mathrm{CDCl}_{3}\right)\end{array}$ & $\begin{array}{l}-522.9 \\
\mathrm{~J}_{\mathrm{Sn}-\mathrm{P}}=286 \mathrm{~Hz} \\
\left(\mathrm{CDCl}_{3}\right)\end{array}$ & [61] \\
\hline 104 & No RX data & & & & & $\begin{array}{l}175.0, \mathrm{t} \\
{ }^{2} \mathrm{~J}_{\mathrm{C}-\mathrm{P}}=18 \mathrm{~Hz}\end{array}$ & $\begin{array}{l}-885, \mathrm{t} \\
\mathrm{J}_{\mathrm{Sn}-\mathrm{P}}=230 \mathrm{~Hz}\end{array}$ & {$[34]$} \\
\hline
\end{tabular}




\begin{tabular}{|c|c|c|c|c|c|c|c|c|}
\hline & & & & & & $\left(\mathrm{CDCl}_{3}\right)$ & $\left(\mathrm{CDCl}_{3}\right)$ & \\
\hline 105 & No RX data & & & & & $\begin{array}{l}170.4, t \\
{ }^{2} J_{C-P}=25 \mathrm{~Hz} \\
\left(\mathrm{C}_{6} \mathrm{D}_{6}\right)\end{array}$ & $\begin{array}{l}-74, \mathrm{t} \\
\mathrm{J}_{\mathrm{Sn}-\mathrm{P}}=161 \mathrm{~Hz} \\
{ }^{1} \mathrm{~J}_{\mathrm{Sn}-\mathrm{W}}=1372 \mathrm{~Hz} \\
\text { (Tol-D } 8 / \mathrm{D}_{2} \mathrm{O}- \\
\text { cap.) }\end{array}$ & [34] \\
\hline 106 & $2.174(3)$ & $2.394(2)$ & $\begin{array}{l}\mathrm{M}=\mathrm{Cr} \\
2.5835(6)\end{array}$ & $\begin{array}{l}2.335(2) \\
2.354(2)\end{array}$ & $\begin{array}{l}\text { Cipso-Sn-Si }_{10} \\
100.76(8) \\
\text { Cipso-Sn- }_{\text {Cr }} \\
\text { 139.23(8) } \\
\end{array}$ & $\begin{array}{l}172.8, \mathrm{t} \\
{ }^{2} \mathrm{~J}_{\mathrm{C}-\mathrm{P}}=25 \mathrm{~Hz} \\
\left(\mathrm{C}_{6} \mathrm{D}_{6}\right)\end{array}$ & $\begin{array}{l}131, \mathrm{t} \\
\mathrm{J}_{\text {Sn-P }}=179 \mathrm{~Hz} \\
\text { (Tol- } \mathrm{D}_{8} / \mathrm{D}_{2} \mathrm{O}- \\
\text { cap.) }\end{array}$ & [34] \\
\hline 107 & No RX data & & & & & $\begin{array}{l}168.4, \mathrm{t} \\
{ }^{2} \mathrm{~J}_{\mathrm{C}-\mathrm{P}}=22 \mathrm{~Hz} \\
\left(\mathrm{CDCl}_{3}\right)\end{array}$ & $\begin{array}{l}54, \mathrm{t} \\
\mathrm{J}_{\text {Sn-P }}=165 \mathrm{~Hz} \\
\text { (Tol-D } / \mathrm{D}_{2} \mathrm{O}- \\
\text { cap.) }\end{array}$ & [34] \\
\hline 108 & $2.181(3)$ & $\begin{array}{l}\mathrm{R}=\mathrm{Cl} \\
2.401(1)\end{array}$ & $\begin{array}{l}\mathrm{M}=\mathrm{W} \\
2.7263(11)\end{array}$ & $\begin{array}{l}2.313(2) \\
2.346(2)\end{array}$ & $97.4(1)$ & $\begin{array}{l}170.6, \mathrm{t} \\
{ }^{2} \mathrm{~J}_{\mathrm{C}-\mathrm{P}}=24 \mathrm{~Hz} \\
\left(\mathrm{C}_{6} \mathrm{D}_{6}\right)\end{array}$ & $\begin{array}{l}-75, \mathrm{t}, \mathrm{J}_{\mathrm{Sn}-\mathrm{P}}=164 \\
\mathrm{~Hz} \\
{ }^{1} \mathrm{~J}_{\mathrm{Sn}-\mathrm{W}}=1366 \mathrm{~Hz} \\
\left(\mathrm{C}_{6} \mathrm{D}_{6}\right)\end{array}$ & {$[64]$} \\
\hline 109 & $2.177(2)$ & $\begin{array}{l}\mathrm{R}=\mathrm{Cl} \\
2.403(1)\end{array}$ & $\begin{array}{l}\mathrm{M}=\mathrm{Cr} \\
2.5783(4)\end{array}$ & $\begin{array}{l}2.316(2) \\
2.347(2)\end{array}$ & $\begin{array}{l}\text { C }_{\text {ipso-Sn- }}- \\
\mathrm{Cl} \\
97.54(6) \\
\text { Cipso-Sn- }_{\text {in }} \\
\mathrm{Cr} \\
141.24(6)\end{array}$ & $\begin{array}{l}171.7, \mathrm{t} \\
{ }^{2} \mathrm{~J}_{\mathrm{C}-\mathrm{P}}=25.8 \mathrm{~Hz} \\
\left(\mathrm{C}_{6} \mathrm{D}_{6}\right)\end{array}$ & $\begin{array}{l}127.9, \mathrm{~J}_{\mathrm{Sn}-\mathrm{P}}=182 \\
\mathrm{~Hz} \\
\left(\mathrm{C}_{6} \mathrm{D}_{6}\right)\end{array}$ & [35] \\
\hline 110 & $2.167(4)$ & $\begin{array}{l}\mathrm{R}=\mathrm{O} \\
2.170(3)\end{array}$ & $\begin{array}{l}\mathrm{M}=\mathrm{Cr} \\
2.5732(7)\end{array}$ & $\begin{array}{l}2.291(3) \\
2.347(3)\end{array}$ & $\begin{array}{l}\text { Cipso-Sn-R } \\
87.7(1)\end{array}$ & $\begin{array}{l}170.4, t,{ }^{2} \mathrm{~J}_{\mathrm{C}-\mathrm{P}}= \\
23.4 \mathrm{~Hz} \\
\left(\mathrm{Tol}_{-} \mathrm{D}_{8}\right)\end{array}$ & $\begin{array}{l}81, \mathrm{t}, \mathrm{J}_{\mathrm{Sn}-\mathrm{P}}=194 \\
\mathrm{~Hz} \\
\left(\mathrm{Tol}-\mathrm{D}_{8}\right)\end{array}$ & [65] \\
\hline 111 & $2.176(3)$ & $\begin{array}{l}\mathrm{R}=\mathrm{O} \\
2.178(3)\end{array}$ & $\begin{array}{l}\mathrm{M}=\mathrm{Cr} \\
2.5546(6)\end{array}$ & $\begin{array}{l}2.322(2) \\
2.332(2)\end{array}$ & $\begin{array}{l}\text { Cipso-Sn-R }_{\text {in }} \\
88.6(1)\end{array}$ & $\begin{array}{l}170.6, t,{ }^{2} \mathrm{~J}_{\mathrm{C}-\mathrm{P}}= \\
23.6 \mathrm{~Hz} \\
\left(\mathrm{Tol}-\mathrm{D}_{8}\right)\end{array}$ & $\begin{array}{l}71, \mathrm{t}, \mathrm{J}_{\mathrm{Sn}-\mathrm{P}}=193 \\
\mathrm{~Hz} \\
\left(\mathrm{Tol}-\mathrm{D}_{8}\right)\end{array}$ & {$[65]$} \\
\hline 112 & $2.157(3)$ & $\begin{array}{l}\mathrm{R}=\mathrm{N} \\
2.166(3)\end{array}$ & $\begin{array}{l}\mathrm{M}=\mathrm{Cr} \\
2.5744(6)\end{array}$ & $\begin{array}{l}2.300(2) \\
2.325(2)\end{array}$ & $\begin{array}{l}\text { C }_{i p s o}-\mathrm{Sn}-\mathrm{R} \\
99.2(1)\end{array}$ & $\begin{array}{l}167.6, t,{ }^{2} \mathrm{~J}_{\mathrm{C}-\mathrm{P}}= \\
22.4 \mathrm{~Hz} \\
\left(\mathrm{C}_{6} \mathrm{D}_{6}\right)\end{array}$ & $\begin{array}{l}115, \mathrm{t}, \mathrm{J}_{\mathrm{Sn}-\mathrm{P}}=143 \\
\mathrm{~Hz} \\
\left(\mathrm{C}_{6} \mathrm{D}_{6}\right)\end{array}$ & {$[65]$} \\
\hline 113 & $2.151(3)$ & $\begin{array}{l}\mathrm{R}=\mathrm{O} \\
2.104(2)\end{array}$ & $\begin{array}{l}\mathrm{M}=\mathrm{Cr} \\
2.5660(5)\end{array}$ & $\begin{array}{l}2.269(2) \\
2.358(2) \\
\end{array}$ & $\begin{array}{l}\text { Cipso }_{\text {ipsn-R }} \\
88.38(9) \\
\end{array}$ & $\begin{array}{l}170.2 \\
\left(\mathrm{CD}_{2} \mathrm{Cl}_{2}\right)\end{array}$ & $\begin{array}{l}67 \\
\left(\mathrm{CD}_{2} \mathrm{Cl}_{2}\right)\end{array}$ & {$[65]$} \\
\hline 114 & $2.188(5)$ & $\begin{array}{l}\mathrm{R}=\mathrm{F} \\
1.974(3)\end{array}$ & $\begin{array}{l}M=W \\
2.7342(4)\end{array}$ & $\begin{array}{l}2.333(4) \\
2.323(4)\end{array}$ & $95.5(1)$ & $\begin{array}{l}170.8, \mathrm{t} \\
{ }^{2} \mathrm{~J}_{\mathrm{C}-\mathrm{P}}=24.8 \mathrm{~Hz} \\
\left(\mathrm{C}_{6} \mathrm{D}_{6}\right)\end{array}$ & $\begin{array}{l}-134, \mathrm{dt}, \mathrm{J}_{\mathrm{Sn}-\mathrm{P}}= \\
164 \mathrm{~Hz} \\
\mathrm{~J}_{\mathrm{Sn}-\mathrm{F}}=3203 \mathrm{~Hz} \\
{ }^{1} \mathrm{~J}_{\mathrm{Sn}-\mathrm{W}}=1389 \mathrm{~Hz} \\
\left(\mathrm{C}_{6} \mathrm{D}_{6}\right)\end{array}$ & [64] \\
\hline 115 & $2.182(3)$ & $\begin{array}{l}\mathrm{R}=\mathrm{P} \\
2.558(1)\end{array}$ & $\begin{array}{l}M=W \\
2.767(3)\end{array}$ & $\begin{array}{l}2.431(2) \\
2.361(2)\end{array}$ & 101.2(1) & $\begin{array}{l}173, \mathrm{~s} \\
\left(\mathrm{C}_{6} \mathrm{D}_{6}\right)\end{array}$ & $\begin{array}{l}\text { 97, dt, } \mathrm{J}_{\mathrm{Sn}-\mathrm{P}}=120 \\
\mathrm{~Hz} \\
\mathrm{~J}_{\mathrm{Sn}-\mathrm{P}}=982 \mathrm{~Hz} \\
\left(\mathrm{C}_{6} \mathrm{D}_{6}\right)\end{array}$ & {$[64]$} \\
\hline 116 & $2.189(3)$ & $\begin{array}{l}\mathrm{R}=\mathrm{P} \\
2.605(1)\end{array}$ & $\begin{array}{l}M=W \\
2.7660(3)\end{array}$ & $\begin{array}{l}2.315(2) \\
2.391(2)\end{array}$ & $99.8(1)$ & $\begin{array}{l}169.5, t,{ }^{2} J_{C-P}= \\
24.6 \mathrm{~Hz} \\
\left(\mathrm{C}_{6} \mathrm{D}_{6}\right)\end{array}$ & $\begin{array}{l}24, \mathrm{~d}, \mathrm{~J}_{\mathrm{Sn}-\mathrm{P}}= \\
1036 \mathrm{~Hz} \\
\left(\mathrm{C}_{6} \mathrm{D}_{6}\right)\end{array}$ & [64] \\
\hline
\end{tabular}




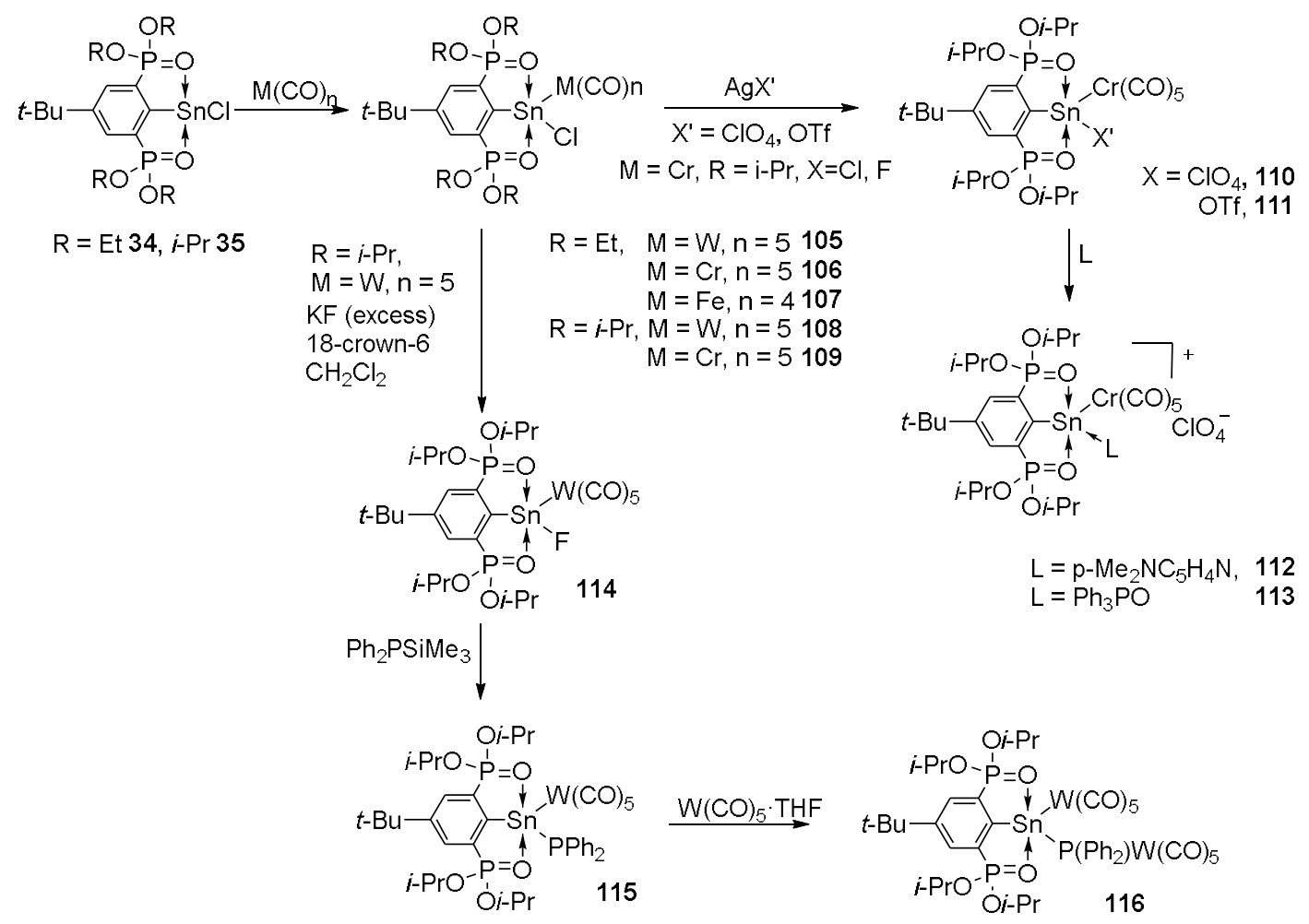

Scheme 15. Formation of stannylene-transition metal complexes and their reactivity

The tungsten-pentacarbonyl complex $\mathbf{1 0 8}$ underwent a halogen exchange in the presence of an excess of $\mathrm{KF}$ to form a fluorido-substituted stannylene complex 114. ${ }^{[64]}$ Complex 114 reacted with $\mathrm{Ph}_{2} \mathrm{PSiMe}_{3}$ to form diphenylphosphanido-substituted derivative 115, which in the presence of $\mathrm{W}(\mathrm{CO})_{5} \cdot \mathrm{THF}$ gave the trimetallic complex 116 through coordination of the lone pair of electrons of the phosphorus atom, as presented in Scheme 15. ${ }^{[64]}$

The chromium-pentacarbonyl stannylene complex 109 gave substitution reactions of the chlorine atom, as depicted in Scheme 15. Triflate- and perchlorate-substituted stannylenes $\mathbf{1 1 0}$ and 111 were obtained by adding AgOTf or $\mathrm{AgClO}_{4}$ to complex 109. The structural features of the substituted complexes are similar to the starting chlorine-substituted complex. ${ }^{[65]}$ Further substitution takes place with the addition of 4-dimethylaminopyridine or triphenylphosphane oxide to form donor stabilized tin(II) perchlorate salts 112 and 113. ${ }^{[65]}$

Other transition metal complexes of the stannylene $\mathbf{3 5}$ were obtained with platinum, palladium and ruthenium, ${ }^{[50,67]}$ as show in Scheme 16. 

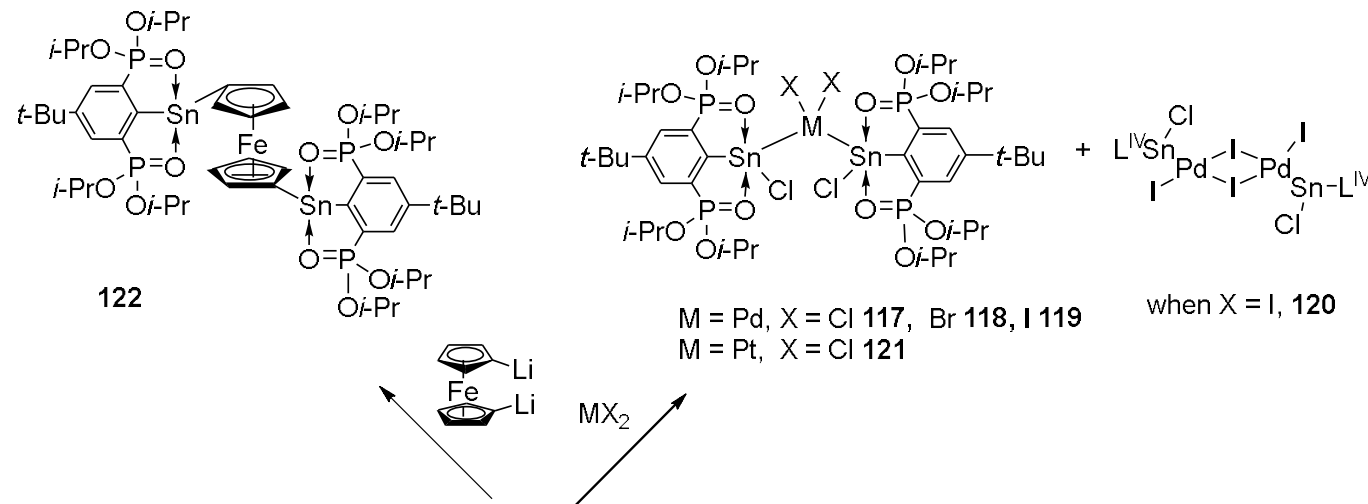

$$
M=P d X=C l 117, B r 118, \mid 119 \quad \text { when } X=I, 120
$$

$M=P t, X=C l 121$
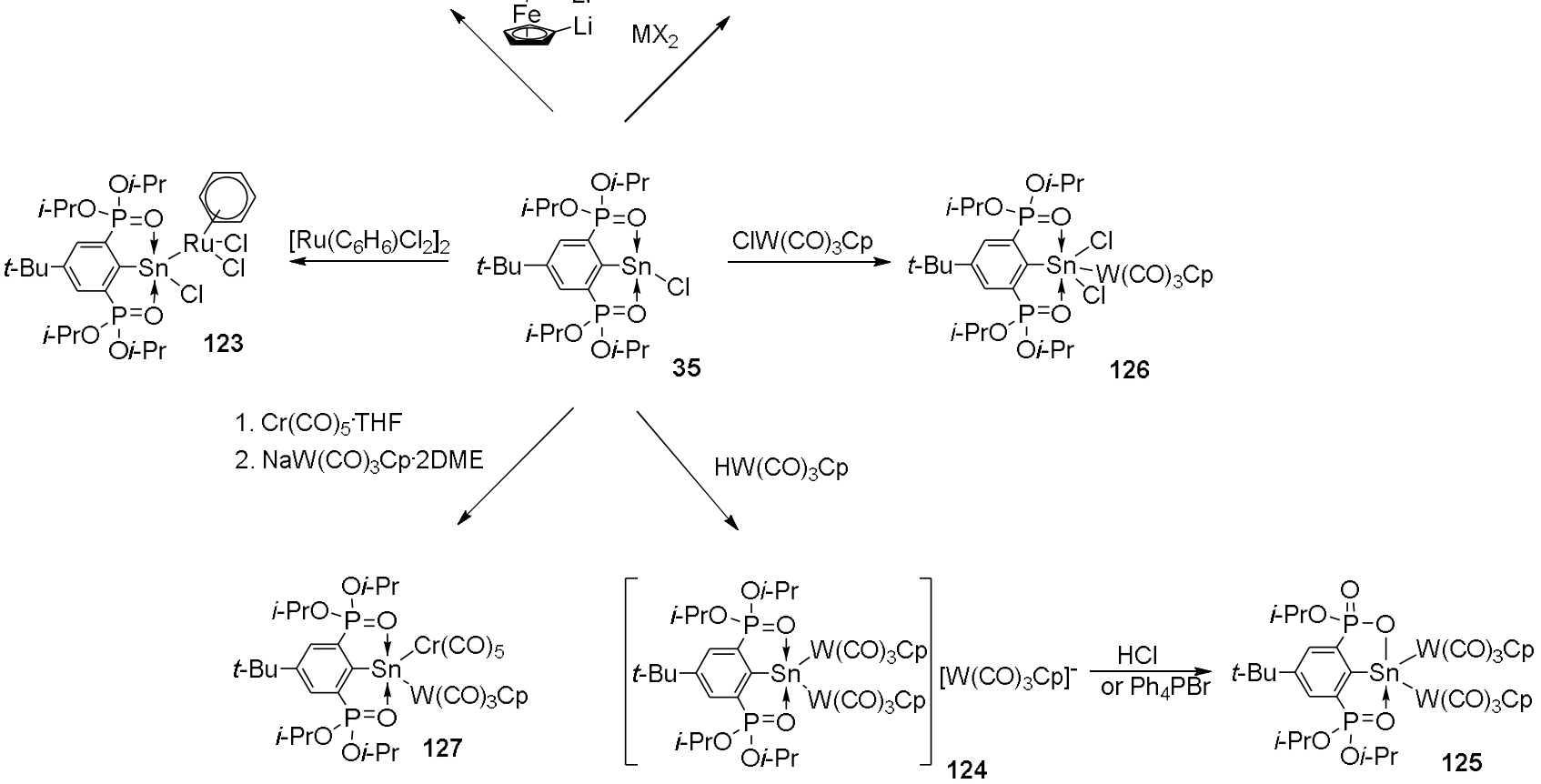

Scheme 16. Reactivity of the stannylene towards transition metals

The NMR spectroscopic analysis and X-ray diffraction showed the characteristics for $\operatorname{Pd}(\mathbf{1 1 7}, 118$, 119), $\mathrm{Pt}(\mathbf{1 2 1})$ and $\mathrm{Ru}(\mathbf{1 2 3})$ complexes, where the stannylenes act as ligands for the metals through coordination of their lone electron pair. The Sn-M (M = Pt, Pd, Ru) distances and the Sn-O distances are in the range of values for similar compounds. ${ }^{[50,67]}$

Stannylene complexes were also obtained containing two transition metal moieties by adding $\mathrm{HW}(\mathrm{CO})_{3} \mathrm{Cp}$ to stannylene 35 to form 124 or by adding $\mathrm{NaW}(\mathrm{CO})_{3} \mathrm{Cp} 2 \mathrm{DME}$ to its chromium complex $\mathrm{L}^{\mathrm{IV}} \mathrm{SnCl}\left(\mathrm{Cr}(\mathrm{CO})_{5}\right)$ to form 127. ${ }^{[68]}$ In the first case $124{ }^{[68]}$ was formed through a spontaneous auto-ionization process of the intermediary $\mathrm{L}^{\mathrm{IV}} \mathrm{Sn}\left\{\mathrm{W}(\mathrm{CO})_{3} \mathrm{Cp}\right\}_{3}$ species. A ferrocenylbridged bis-stannylene 122 was obtained from stannylene $\mathbf{3 5}$ by adding 1,1'-dilithiumferrocenyl, as shown in Scheme 16. Then, in reaction with $\mathrm{W}(\mathrm{CO})_{6}$ and $\mathrm{C}_{7} \mathrm{H}_{8} \mathrm{Cr}(\mathrm{CO})_{4}$ transition metal complexes formed, where the bis-stannylene acts as a bis-monodentate ligand (in the case of the tungsten complex) or as a bidentate-chelating ligand (in the case of the chromium complex). ${ }^{[69]}$ These compounds were tested for their redox activity by electrochemical techniques, showing that the stannylene moieties act as electron donors, increasing the electron density on the ferrocene core, resulting an easier oxidation than in the case of the unsubstituted ferrocene. ${ }^{[69]}$ 
Table 8. Physical-chemical data for O,C,O-pincer stabilized stannylene derivatives

\begin{tabular}{|c|c|c|c|c|c|c|c|c|}
\hline & $\begin{array}{c}\text { Cipso-Sn bond }_{\text {ingth }(\AA)} \\
\text { lents }\end{array}$ & $\begin{array}{l}\text { Sn-R bond } \\
\text { length }(\AA)\end{array}$ & $\begin{array}{l}\text { Sn-M bond } \\
\text { length }(\AA)\end{array}$ & $\begin{array}{c}\mathrm{O} \rightarrow \text { Sn bond } \\
\text { length }(\AA)\end{array}$ & $\begin{array}{c}\mathrm{C}_{i p s s}-\mathrm{Sn}-\mathrm{R} \\
\text { bond angle }\left({ }^{\circ}\right)\end{array}$ & $\begin{array}{c}{ }^{13} \mathrm{C} \text { NMR } \\
\delta \mathrm{C}_{\text {ipso }}(\mathrm{ppm}) \\
\text { (solvent) } \\
\end{array}$ & $\begin{array}{c}{ }^{119} \text { Sn NMR } \\
\text { (ppm) } \\
\text { (solvent) } \\
\end{array}$ & Ref \\
\hline 117 & $\begin{array}{l}2.171(4) \\
2.175(4)\end{array}$ & $\begin{array}{l}\mathrm{R}=\mathrm{Cl} \\
2.390(1) \\
2.391(1)\end{array}$ & $\begin{array}{l}\mathrm{M}=\mathrm{Pd} \\
2.4742(5) \\
2.4659(5)\end{array}$ & $\begin{array}{l}2.304(3) \\
2.302(3) \\
2.339(3) \\
2.314(3)\end{array}$ & $\begin{array}{l}C_{i p s o}-\mathrm{Sn}-\mathrm{Cl} \\
95.88(9) \\
94.7(1) \\
\text { Cipso-Sn-M }_{1} \\
134.67(9) \\
137.76(9)\end{array}$ & $\begin{array}{l}166.1, \mathrm{t} \\
{ }^{2} \mathrm{~J}_{\mathrm{C}-\mathrm{P}}=21.4 \mathrm{~Hz} \\
\left(\mathrm{CD}_{2} \mathrm{Cl}_{2}\right)\end{array}$ & $\begin{array}{l}-363, \mathrm{t} \\
\mathrm{J}_{\mathrm{Sn}-\mathrm{P}}=178 \mathrm{~Hz} \\
\mathrm{~J}_{\mathrm{Sn}-\mathrm{Sn}}=4490 \mathrm{~Hz} \\
\left(\mathrm{CD}_{2} \mathrm{Cl}_{2}\right)\end{array}$ & {$[50]$} \\
\hline 118 & $\begin{array}{l}2.145(10) \\
2.146(9)\end{array}$ & $\begin{array}{l}\mathrm{R}=\mathrm{Cl} \\
2.493(3) \\
2.464(3)\end{array}$ & $\begin{array}{l}\mathrm{M}=\mathrm{Pd} \\
2.474(1) \\
2.464(1)\end{array}$ & $\begin{array}{l}2.325(6) \\
2.302(6) \\
2.361(6) \\
2.291(6)\end{array}$ & $\begin{array}{l}\text { Cipso-Sn-Cl }_{\text {ins }}-\mathrm{S} .6(2) \\
95.0(2) \\
94.0 \\
\text { Cipso-Sn-M }_{1} \text { 136.9(2) } \\
137.1(2) \\
\end{array}$ & $\begin{array}{l}167.8, \mathrm{t} \\
{ }^{2} \mathrm{~J}_{\mathrm{C}-\mathrm{P}}=21.4 \mathrm{~Hz} \\
\left(\mathrm{CD}_{2} \mathrm{Cl}_{2}\right)\end{array}$ & $\begin{array}{l}-321, \mathrm{t} \\
\mathrm{J}_{\mathrm{Sn}-\mathrm{P}}=178 \mathrm{~Hz} \\
\mathrm{~J}_{\mathrm{Sn}-\mathrm{Sn}}=5640 \mathrm{~Hz} \\
\left(\mathrm{CD}_{2} \mathrm{Cl}_{2}\right)\end{array}$ & {$[50]$} \\
\hline 119 & $2.159(3)$ & $\begin{array}{l}\mathrm{R}=\mathrm{Cl} \\
2.398(1)\end{array}$ & $\begin{array}{l}\mathrm{M}=\mathrm{Pd} \\
2.4945(3)\end{array}$ & $\begin{array}{l}2.326(2) \\
2.335(2)\end{array}$ & $\begin{array}{l}\text { Cipso- }_{\text {ipn-Cl }} \\
94.75(8) \\
\text { Cipso-Sn-M }_{\text {ips }} \\
135.95(8) \\
\end{array}$ & $\begin{array}{l}170.6, \mathrm{t} \\
{ }^{2} \mathrm{~J}_{\mathrm{C}-\mathrm{P}}=21.4 \mathrm{~Hz} \\
\left(\mathrm{CD}_{2} \mathrm{Cl}_{2}\right)\end{array}$ & $\begin{array}{l}-257, \mathrm{t}, \\
\mathrm{J}_{\mathrm{Sn}-\mathrm{P}}=192 \mathrm{~Hz} \\
\mathrm{~J}_{\mathrm{Sn}-\mathrm{Sn}}=6480 \mathrm{~Hz} \\
\left(\mathrm{CD}_{2} \mathrm{Cl}_{2}\right)\end{array}$ & {$[50]$} \\
\hline 120 & $2.147(15)$ & $\begin{array}{l}\mathrm{R}=\mathrm{Cl} \\
2.419(4)\end{array}$ & $\begin{array}{l}\mathrm{M}=\mathrm{Pd} \\
2.4804(15)\end{array}$ & $\begin{array}{l}2.312(9) \\
2.272(8)\end{array}$ & $\begin{array}{l}\mathbf{C}_{i p s o}-\mathrm{Sn}-\mathrm{Cl} \\
102.3(4) \\
\text { C }_{\text {ipso }}-\mathrm{Sn}-\mathrm{M} \\
135.5(4)\end{array}$ & No data & No data & {$[50]$} \\
\hline 121 & $\begin{array}{l}2.172(13) \\
2.186(14)\end{array}$ & $\begin{array}{l}\mathrm{R}=\mathrm{Cl} \\
2.380(1) \\
2.388(4)\end{array}$ & $\begin{array}{l}\mathrm{M}=\mathrm{Pt} \\
2.469(1) \\
2.476(1)\end{array}$ & $\begin{array}{l}2.272(9) \\
2.295(8) \\
2.318(9) \\
2.316(8)\end{array}$ & $\begin{array}{l}C_{i p s o}-\mathrm{Sn}-\mathrm{Cl} \\
101.1(3) \\
102.7(3) \\
\text { Cipso-Sn-M }_{1} \\
126.9(3) \\
128.5(3) \\
\end{array}$ & $\begin{array}{l}163.9, \mathrm{t} \\
{ }^{2} \mathrm{~J}_{\mathrm{C}-\mathrm{P}}=20.9 \mathrm{~Hz} \\
\left(\mathrm{CD}_{2} \mathrm{Cl}_{2}\right)\end{array}$ & $\begin{array}{l}-438, \mathrm{t} \\
\mathrm{J}_{\mathrm{Sn}-\mathrm{P}}=130 \mathrm{~Hz} \\
\mathrm{~J}_{\mathrm{Sn}-\mathrm{Sn}}=1500 \mathrm{~Hz} \\
\left(\mathrm{CD}_{2} \mathrm{Cl}_{2}\right)\end{array}$ & {$[50]$} \\
\hline 121 & $2.115(5)$ & $\begin{array}{l}\mathrm{R}=\mathrm{Cl} \\
2.3828(15)\end{array}$ & $\begin{array}{l}\mathrm{M}=\mathrm{Pt} \\
2.4865(4)\end{array}$ & & $\begin{array}{l}\mathbf{C}_{i p s o}-\mathrm{Sn}-\mathrm{Cl} \\
98.74(14) \\
\text { C-Sn-M } \\
138.6(1) \\
\end{array}$ & Not assigned & $\begin{array}{l}-254 \\
\mathrm{~J}_{\mathrm{Sn}-\mathrm{Pt}}=12640 \\
\mathrm{~Hz} \\
\left(\mathrm{CDCl}_{3}\right)\end{array}$ & {$[50]$} \\
\hline 122 & $2.241(2)$ & $\begin{array}{l}\mathrm{R}=\mathrm{C} \\
2.181(2)\end{array}$ & - & $\begin{array}{l}2.472(2) \\
2.491(2)\end{array}$ & $91.80(7)$ & $\begin{array}{l}187.4, \mathrm{t} \\
{ }^{2} \mathrm{~J}_{\mathrm{C}-\mathrm{P}}=37.9 \mathrm{~Hz} \\
\left(\mathrm{C}_{6} \mathrm{D}_{6}\right)\end{array}$ & $\begin{array}{l}117, J_{\text {Sn-P }}=92 \\
\mathrm{~Hz} \\
\left(\mathrm{C}_{6} \mathrm{D}_{6}\right)\end{array}$ & [69] \\
\hline 123 & $2.158(4)$ & $\begin{array}{l}\mathrm{R}=\mathrm{Cl} \\
2.4283(13)\end{array}$ & $\begin{array}{l}\mathrm{M}=\mathrm{Ru} \\
2.5856(6)\end{array}$ & $\begin{array}{l}2.291(3) \\
2.394(3)\end{array}$ & $\begin{array}{l}\text { Cipso-Sn-Cl }-\mathrm{S} \\
96.04(12) \\
\text { Cipso-Sn-M }_{12} \\
140.99(12) \\
\end{array}$ & No data & $\begin{array}{l}-387, \mathrm{t}, \\
\mathrm{J}_{\mathrm{Sn}-\mathrm{P}}=242 \mathrm{~Hz} \\
\left(\mathrm{C}_{6} \mathrm{D}_{6}\right)\end{array}$ & {$[67]$} \\
\hline 124 & $2.207(8)$ & - & $\begin{array}{l}\mathrm{M}=\mathrm{W} \\
2.8557(7) \\
2.8391(8)\end{array}$ & $\begin{array}{l}2.363(6) \\
2.415(6)\end{array}$ & $\begin{array}{l}\text { Cipso-Sn-M }_{1} \\
117.1(2) \\
116.5(2)\end{array}$ & $\begin{array}{l}164.7, \mathrm{t} \\
{ }^{2} \mathrm{~J}_{\mathrm{C}-\mathrm{P}}=24.0 \mathrm{~Hz} \\
\left(\mathrm{CDCl}_{3}\right)\end{array}$ & $\begin{array}{l}1, \mathrm{t}, \\
\mathrm{J}_{\mathrm{Sn}-\mathrm{P}}=103 \mathrm{~Hz} \\
\mathrm{~J}_{\mathrm{Sn}-\mathrm{W}}=468 \mathrm{~Hz} \\
\left(\mathrm{THF} / \mathrm{C}_{6} \mathrm{D}_{6^{-}}\right. \\
\text {capillary) }\end{array}$ & {$[68]$} \\
\hline 125 & No RX data & & & & & Not assigned & $\begin{array}{l}-53, \mathrm{dd} \\
\mathrm{J}_{\mathrm{Sn}-\mathrm{P}}=67 \mathrm{~Hz} \\
\mathrm{~J}_{\mathrm{Sn}-\mathrm{P}}=115 \mathrm{~Hz} \\
\left(\mathrm{CDCl}_{3}\right)\end{array}$ & {$[68]$} \\
\hline 126 & $2.154(4)$ & $\begin{array}{l}\mathrm{R}=\mathrm{Cl} \\
2.6006(12) \\
2.5893(13)\end{array}$ & $\begin{array}{l}M=W \\
2.8034(4)\end{array}$ & $\begin{array}{l}2.360(3) \\
2.293(3)\end{array}$ & $\begin{array}{l}\text { C }_{\text {ipso }} \text {-Sn-Cl } \\
81.53 \\
83.42 \\
\text { C }_{\text {ipso }}-\mathrm{Sn}-\mathrm{M} \\
172.51(13) \\
\end{array}$ & No data & $\begin{array}{l}-564, \mathrm{t} \\
\mathrm{J}_{\mathrm{Sn}-\mathrm{P}}=95 \mathrm{~Hz} \\
\mathrm{~J}_{\mathrm{Sn}-\mathrm{W}}=1366 \mathrm{~Hz} \\
\left(\mathrm{C}_{6} \mathrm{D}_{6}\right)\end{array}$ & {$[68]$} \\
\hline 127 & $2.212(4)$ & & $\begin{array}{l}\mathrm{M}=\mathrm{W} \\
2.8883(4) \\
\mathrm{M}=\mathrm{Cr} \\
2.6397(8)\end{array}$ & $\begin{array}{l}2.406(3) \\
2.415(3)\end{array}$ & $\begin{array}{l}\mathbf{C}_{\text {ipso-Sn-M }}-\mathrm{S} \\
110.23(12) \\
125.97(12)\end{array}$ & $\begin{array}{l}174.4, \mathrm{t} \\
{ }^{2} \mathrm{~J}_{\mathrm{C}-\mathrm{P}}=26.7 \mathrm{~Hz} \\
\left(\mathrm{CDCl}_{3}\right)\end{array}$ & $\begin{array}{l}407, \mathrm{t} \\
\mathrm{J}_{\mathrm{Sn}-\mathrm{P}}=127 \mathrm{~Hz} \\
\left(\mathrm{THF} / \mathrm{D}_{2} \mathrm{O}-\right. \\
\text { capillary) }\end{array}$ & {$[68]$} \\
\hline 128 & $\begin{array}{l}2.238(6) \\
2.254(6)\end{array}$ & $\begin{array}{l}\mathrm{R}=\mathrm{Sn} \\
3.0486(6)\end{array}$ & - & $\begin{array}{l}2.459(4) \\
2.527(5) \\
2.510(4) \\
2.504(4)\end{array}$ & $\begin{array}{l}\mathbf{C}_{i p s o}-\mathrm{Sn}-\mathrm{Sn} \\
97.87(16) \\
98.14(16)\end{array}$ & $\begin{array}{l}195, \mathrm{t} \\
{ }^{2} \mathrm{~J}_{\mathrm{C}-\mathrm{P}}=36 \mathrm{~Hz} \\
\left(\mathrm{C}_{6} \mathrm{D}_{6}\right)\end{array}$ & $\begin{array}{l}359, \mathrm{t}, \mathrm{J}_{\mathrm{Sn}-\mathrm{P}}= \\
81 \mathrm{~Hz} \\
\mathrm{~J}_{\mathrm{Sn}-\mathrm{Sn}}=1455 \mathrm{~Hz} \\
\left(\mathrm{C}_{6} \mathrm{D}_{6}\right)\end{array}$ & {$[70]$} \\
\hline 129 & $2.295(2)$ & - & - & $\begin{array}{l}2.4970(14) \\
3.1302(14)\end{array}$ & $\begin{array}{l}\text { Cipso-Sn- }_{\text {-Sn }} \\
\text { Cipso } \mathrm{A} \\
\end{array}$ & $\begin{array}{l}193, \mathrm{t} \\
{ }^{2} \mathrm{~J}_{\mathrm{C}-\mathrm{P}}=36 \mathrm{~Hz}\end{array}$ & $\begin{array}{l}3, \text { quintet } \\
\mathrm{J}_{\mathrm{Sn}-\mathrm{P}}=101 \mathrm{~Hz}\end{array}$ & [70] \\
\hline
\end{tabular}




\begin{tabular}{|c|c|c|c|c|c|c|c|c|}
\hline & & & & & $99.10(10)$ & $\left(\mathrm{C}_{6} \mathrm{D}_{6}\right)$ & $\left(\mathrm{C}_{6} \mathrm{D}_{6}\right)$ & \\
\hline 130 & No RX data & & & & & No data & $\begin{array}{l}-560, \mathrm{t} \\
\mathrm{J}_{\mathrm{Sn}-\mathrm{P}}=38 \mathrm{~Hz} \\
\left(\mathrm{C}_{6} \mathrm{D}_{6} / \mathrm{THF}\right)\end{array}$ & [71] \\
\hline 131 & $2.155(3)$ & $\begin{array}{l}\mathrm{R}=\mathrm{S} \\
2.4907(9) \\
2.5016(9)\end{array}$ & & $\begin{array}{l}2.1335(19) \\
2.8425(19)\end{array}$ & $\begin{array}{l}\text { Cipso-Sn-S }_{1}-{ }_{10} \\
106.96 \\
109.67\end{array}$ & $\begin{array}{l}158.1, \mathrm{dd} \\
{ }^{2} \mathrm{~J}_{\mathrm{C}-\mathrm{P}}=14.1 \mathrm{~Hz} \\
{ }^{2} \mathrm{~J}_{\mathrm{C}-\mathrm{P}}=19.0 \mathrm{~Hz} \\
\left(\mathrm{C}_{6} \mathrm{D}_{6}\right)\end{array}$ & $\begin{array}{l}-503, \mathrm{dd} \\
\mathrm{J}_{\mathrm{Sn}-\mathrm{P}}=51 \mathrm{~Hz} \\
\mathrm{~J}_{\mathrm{Sn}-\mathrm{P}}=130 \mathrm{~Hz} \\
\left(\mathrm{C}_{6} \mathrm{D}_{6}\right)\end{array}$ & [71] \\
\hline 132 & $2.234(5)$ & $\begin{array}{l}\mathrm{R}=\mathrm{O} \\
2.112(3)\end{array}$ & - & $\begin{array}{l}2.455(3) \\
2.421(3)\end{array}$ & $84.02(15)$ & $\begin{array}{l}187, \mathrm{t} \\
{ }^{2} \mathrm{~J}_{\mathrm{C}-\mathrm{P}}=36.7 \mathrm{~Hz} \\
\left(\mathrm{C}_{6} \mathrm{D}_{6}\right)\end{array}$ & $\begin{array}{l}-229, \mathrm{t} \\
\mathrm{J}_{\mathrm{Sn}-\mathrm{P}}=106 \mathrm{~Hz} \\
\left(\mathrm{C}_{6} \mathrm{D}_{6}\right)\end{array}$ & [70] \\
\hline 133 & $2.223(2)$ & $\begin{array}{l}\mathrm{R}=\mathrm{Se} \\
2.6373(3)\end{array}$ & - & $\begin{array}{l}2.4612(14) \\
2.4406(14)\end{array}$ & $89.56(5)$ & $\begin{array}{l}183.5, \mathrm{t} \\
{ }^{2} \mathrm{~J}_{\mathrm{C}-\mathrm{P}}=35.0 \mathrm{~Hz} \\
\left(\mathrm{C}_{6} \mathrm{D}_{6}\right)\end{array}$ & $\begin{array}{l}45, \mathrm{t}, \mathrm{J}_{\mathrm{Sn}-\mathrm{P}}=98 \\
\mathrm{~Hz} \\
\mathrm{~J}_{\mathrm{Sn}-\mathrm{Se}}=985 \mathrm{~Hz} \\
\left(\mathrm{C}_{6} \mathrm{D}_{6}\right)\end{array}$ & [71] \\
\hline \begin{tabular}{|l|}
134 \\
\end{tabular} & $2.221(3)$ & $\begin{array}{l}\mathrm{R}=\mathrm{Te} \\
2.8514(3)\end{array}$ & - & $\begin{array}{l}2.437(2) \\
2.456(2)\end{array}$ & $88.74(8)$ & $\begin{array}{l}182.8, \mathrm{t} \\
{ }^{2} \mathrm{~J}_{\mathrm{C}-\mathrm{P}}=34.9 \mathrm{~Hz} \\
\left(\mathrm{C}_{6} \mathrm{D}_{6}\right)\end{array}$ & $\begin{array}{l}97, \mathrm{t} \\
\mathrm{J}_{\mathrm{Sn}-\mathrm{P}}=101 \mathrm{~Hz} \\
\mathrm{~J}_{\mathrm{Sn}-\mathrm{Te}}=2117 \mathrm{~Hz} \\
\left(\mathrm{C}_{6} \mathrm{D}_{6}\right)\end{array}$ & [71] \\
\hline 135 & $2.240(3)$ & $\begin{array}{l}\mathrm{R}=\mathrm{S} \\
2.5280(7)\end{array}$ & - & $\begin{array}{l}2.4069(17) \\
2.4971(17)\end{array}$ & $85.45(6)$ & $\begin{array}{l}185.5, \mathrm{t} \\
{ }^{2} \mathrm{~J}_{\mathrm{C}-\mathrm{P}}=36.0 \mathrm{~Hz} \\
\left(\mathrm{C}_{6} \mathrm{D}_{6}\right)\end{array}$ & $\begin{array}{l}-88.5, \mathrm{t} \\
\mathrm{J}_{\mathrm{Sn}-\mathrm{P}}=94 \mathrm{~Hz} \\
\left(\mathrm{C}_{6} \mathrm{D}_{6}\right)\end{array}$ & [71] \\
\hline 136 & $2.141(4)$ & $\begin{array}{l}\mathrm{R}=\mathrm{Se} \\
2.5056(5) \\
\mathrm{R} 2=\mathrm{Cl} \\
2.4544(10) \\
\mathrm{R} 3=\mathrm{Cl} \\
2.5108(11)\end{array}$ & & $\begin{array}{l}2.241(3) \\
2.235(3)\end{array}$ & $170.42(11)$ & $\begin{array}{l}175.2, \mathrm{t} \\
{ }^{2} \mathrm{~J}_{\mathrm{C}-\mathrm{P}}=18.0 \mathrm{~Hz} \\
\left(\mathrm{C}_{6} \mathrm{D}_{6}\right)\end{array}$ & $\begin{array}{l}-588, \mathrm{t} \\
\mathrm{J}_{\mathrm{Sn}-\mathrm{P}}=83 \mathrm{~Hz} \\
\left(\mathrm{C}_{6} \mathrm{D}_{6}\right)\end{array}$ & [71] \\
\hline 137 & No RX data & & & & & $\begin{array}{l}134.6 \\
\left(\mathrm{THF}-\mathrm{D}_{8}\right)\end{array}$ & Not seen & {$[28]$} \\
\hline \begin{tabular}{|l|}
138 \\
\end{tabular} & $2.194(4)$ & $\begin{array}{l}\mathrm{R}=\mathrm{O}_{\text {quinone }} \\
2.023(3) \\
2.007(2) \\
\mathrm{R}=\mathrm{O}_{\text {bridge }} \\
2.069(3 \\
2.112(3)\end{array}$ & & $\begin{array}{l}3.309(3) \\
2.308(3)\end{array}$ & $\begin{array}{l}\text { Cipso-Sn- }-{ } \\
\text { Obridge } \\
111.98(14) \\
98.15(12)\end{array}$ & Not seen & Not seen & [28] \\
\hline \begin{tabular}{|l|}
139 \\
\end{tabular} & $2.389(6)$ & $\mathrm{R}=\mathrm{Cl}$ & $\begin{array}{l}\mathrm{M}=\mathrm{Fe} \\
2.442(1)\end{array}$ & $\begin{array}{l}2.354(2) \\
2.377(2) \\
\end{array}$ & $98.42(6)$ & $\begin{array}{l}150.6 \\
\left(\mathrm{THF}-\mathrm{D}_{8}\right)\end{array}$ & $\begin{array}{l}192.5 \\
\left(\mathrm{THF}-\mathrm{D}_{8}\right)\end{array}$ & {$[22]$} \\
\hline 140 & $2.162(4)$ & $\begin{array}{l}\mathrm{R}=\mathrm{Cl} \\
2.358(1)\end{array}$ & $\begin{array}{l}M=W \\
2.718(5)\end{array}$ & $\begin{array}{l}2.381(3) \\
2.416(3)\end{array}$ & $97.20(12)$ & $\begin{array}{l}147.9 \\
\left(\mathrm{CDCl}_{3}\right)\end{array}$ & No data & [22] \\
\hline
\end{tabular}


The reaction of stannylene 35 with $\mathrm{KC}_{8}$ or sodium naphthalenide gave the organotin(I) derivative 128. ${ }^{[70]}$ The solid state structure revealed that the $\mathrm{Sn}-\mathrm{Sn}$ bond length is of 3.0486(6) $\AA$, suggesting a single bond. The Sn-O interactions of 2.430(2) and 2.427(2) A (see Table 8) are slightly longer than in the starting stannylene 35. The tin(I) compound disproportionated to form a diorganostannylene 129 and elemental tin. When adding PySSPy, the tetravalent tin derivative 130 was formed with three -SPy groups linked to the tin atom, then after heating gave a benzoxaphosphastannole derivative $\mathbf{1 3 1}$ through a cyclization reaction, as shown in Scheme 17. [71] The organotin(I) compound 128 in the presence of $\mathrm{PhI}(\mathrm{OAc})_{2}$ gave tin(II) acetate 132. ${ }^{[70]}$

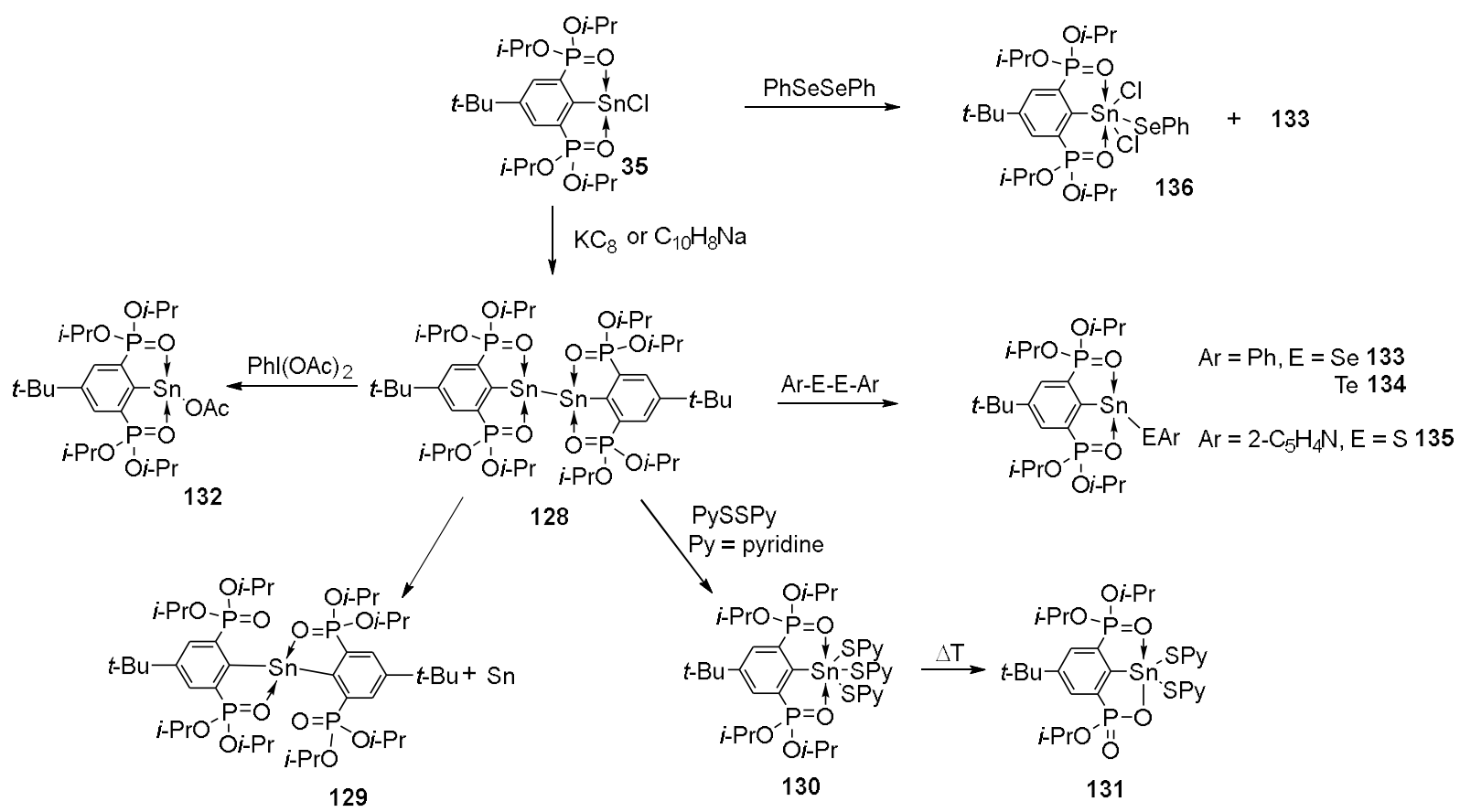

Scheme 17. Synthesis and reactivity of tin(I) derivative

The organotin(I) derivative 128 reacted with diaryl dichalcogenides (Ar-E-E-Ar, E = S, Se, $\mathrm{Te}, \mathrm{Ar}=\mathrm{Ph}, \mathrm{Py})$ to give divalent and tetravalent tin derivatives, as shown in Scheme 17. ${ }^{[7]}$ In the tin(II) arylchalcogenolates $\mathbf{1 3 3}, \mathbf{1 3 4}, \mathbf{1 3 5}$, the tin atom is four coordinated and the Sn-O coordinative bond lengths have values between 2.4069(17) and 2.4971(17) $\AA,{ }^{[71]}$ close to those in chlorostannylene 35. The $\mathbf{C}_{i p s o}-\mathrm{Sn}-\mathrm{E}(\mathrm{E}=\mathrm{S}, \mathrm{Se}, \mathrm{Te})$ bond angles in compounds $\mathbf{1 3 3}, \mathbf{1 3 4}, 135$ are relatively small $\left(85.45(6)^{\circ}-89.56(5)^{\circ}\right)$ suggesting a high $s$ character of the lone electron pair on the divalent tin atom. [71] 

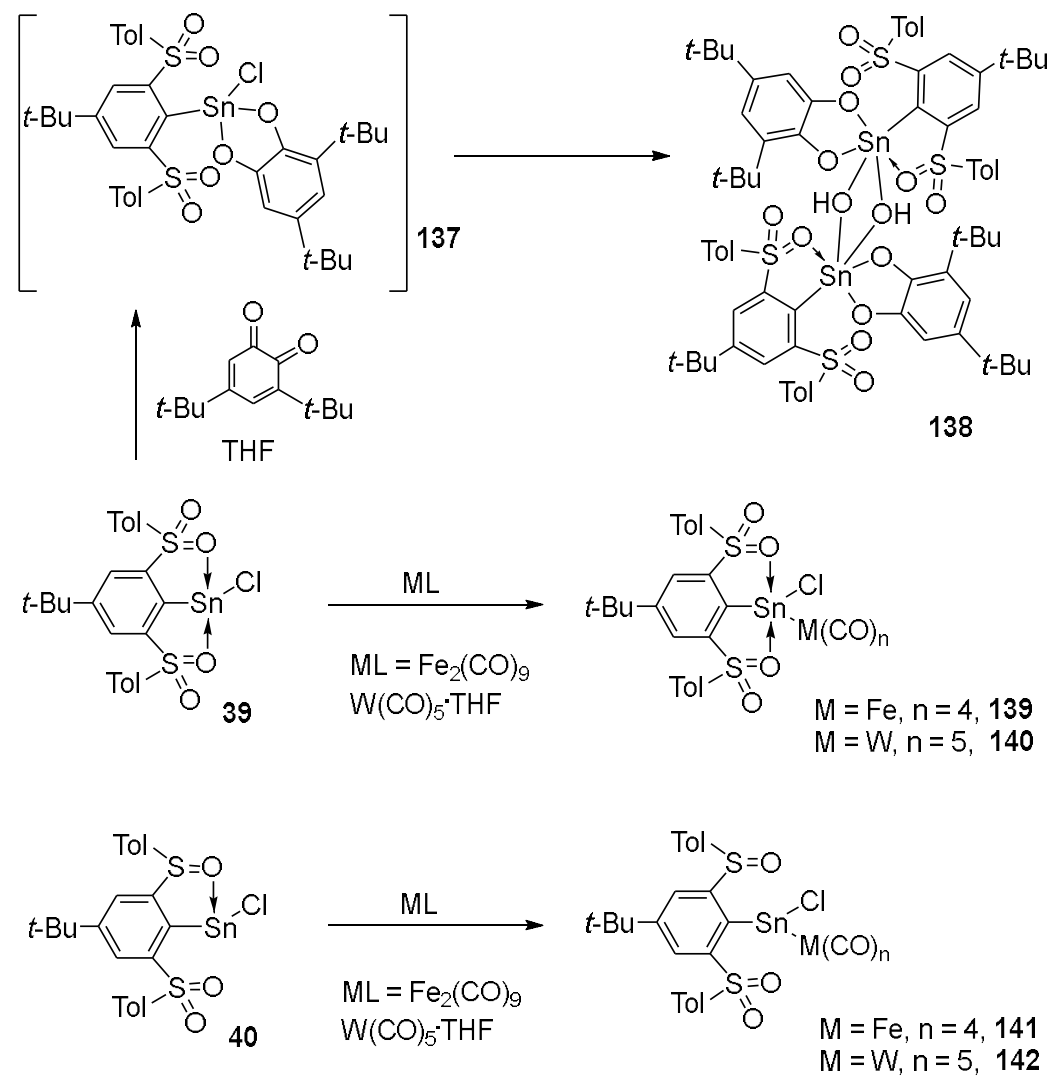

Scheme 18. Reactivity of stannylenes

The stannylenes 39 and 40 , stabilized by the bis-sulfone ligand $\mathrm{L}^{\mathrm{V}}(\mathrm{R}=t$-Bu) and the sulfonesulfoxide ligand $\mathrm{L}^{\mathrm{VI}}$, showed good reactivity towards iron and tungsten carbonyls forming complexes 139-142. (Scheme 18$)^{[22,23]}$ Stannylene 39 reacted with o-benzoquinone, leading to cycloadduct 137, that over time formed the dimeric compound $\mathbf{1 3 8}$ in presence of traces of moisture. (Scheme 18) ${ }^{[28]}$

\section{Plumbylenes}

In the case of plumbylenes, there are a few examples where the stabilization is realized through a pincer ligand; however, these were not as much investigated as the corresponding germanium and tin species.

Plumbylene 143 was obtained, as shown in Scheme 19. The NMR spectra showed characteristic signals for pincer ligand stabilized metallylenes, while the X-ray analysis revealed that the 2,6-diiminophenyl group acts as a tridentate ligand to the divalent lead atom. The $\mathrm{Pb}-\mathrm{N}$ interactions are 2.637(16) and 2.691(17) $\AA .{ }^{[72]}$ The reaction plumbylene 143 with $\mathrm{Li}$ in excess led to the formation of a plumbylidene anion. The treatment of anionic species 144 with $\mathrm{SnCl}_{2}$ in THF gave the 2,6-diiminophenyl-lead(I) dimer 145, as presented in Scheme 19. ${ }^{[72]}$ 


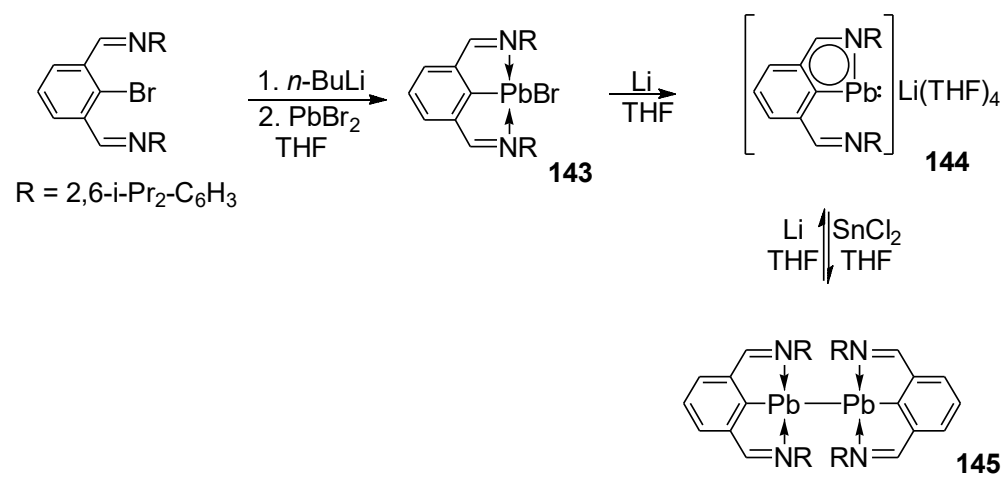

Scheme 19. Synthesis and reactivity of the N,C,N-pincer stabilized plumbylene

Phosphonate based O,C,O-pincer ligands were also used to obtain plumbylenes (146 and 147), as shown in Scheme 20. ${ }^{[35,73]}$

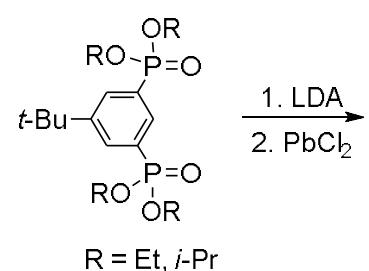

$\mathrm{R}=\mathrm{Et} \cdot \mathrm{i}-\mathrm{Pr}$

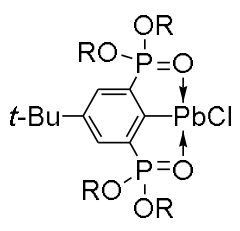

$\begin{array}{ll}\mathrm{R}=\mathrm{Et} & \mathbf{1 4 6} \\ i-\mathrm{Pr} & \mathbf{1 4 7}\end{array}$

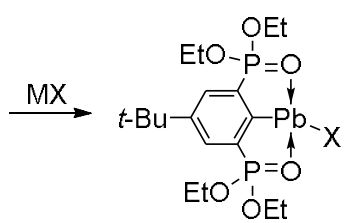

$\mathrm{R}=\mathrm{Et}, \mathrm{M}=\mathrm{Na} \cdot \mathrm{X}=\mathrm{SPh}$

$\mathrm{M}=\mathrm{Li}, \mathrm{X}=\mathrm{N}(i-\mathrm{Pr})_{2}$ $\mathrm{X}=\mathrm{CH}\left(\mathrm{SiMe}_{3}\right)_{2} \quad 150$

Scheme 20. Synthesis and reactivity of the O,C,O-pincer stabilized plumbylenes.

The NMR data revealed the characteristic signals of metallylenes stabilized by such ligands. The solid state structures showed that the Pb-O distances are 2.518(2) $\AA$ in 146 and 2.560(2) $\AA$ in analogue 147 (Scheme 20, Table 9). ${ }^{[35,73]}$ 
Table 9. Physical-chemical data for pincer stabilized plumbylenes and their derivatives

\begin{tabular}{|c|c|c|c|c|c|c|}
\hline & $\begin{array}{l}\text { C-Pb bond } \\
\text { length }(\AA)\end{array}$ & $\begin{array}{l}\text { Pb-R bond } \\
\text { length }(\AA)\end{array}$ & $\begin{array}{c}\mathbf{E} \rightarrow \mathbf{P b} \text { bond } \\
\text { length }(\AA)\end{array}$ & $\begin{array}{c}\text { C-Pb-R bond angle } \\
\left({ }^{\circ}\right)\end{array}$ & $\begin{array}{c}{ }^{13} \mathrm{C} \text { NMR } \\
\delta \mathrm{C}_{i p s o}(\mathrm{ppm}) \\
\text { (solvent) }\end{array}$ & Ref \\
\hline 143 & $2.289(19)$ & $\begin{array}{c}\mathrm{R}=\mathrm{Br} \\
2.701(2)\end{array}$ & $\begin{array}{c}E=N \\
2.637(16) \\
2.691(17)\end{array}$ & $95.0(4)$ & 150.47 & [72] \\
\hline 144 & $2.180(5)$ & - & $\begin{array}{c}\mathrm{E}=\mathrm{N} \\
2.425(5)\end{array}$ & - & 154.24 & [72] \\
\hline 145 & $\begin{array}{l}2.287(11) \\
2.240(11)\end{array}$ & $\begin{array}{c}\mathrm{R}=\mathrm{Pb} \\
3.1283(6)\end{array}$ & $\begin{array}{c}\mathrm{E}=\mathrm{N} \\
2.613(10) \\
2.706(9) \\
2.715(9) \\
2.650(8) \\
\end{array}$ & $\begin{array}{l}111.3(3) \\
105.7(3)\end{array}$ & 149.75 & {$[72]$} \\
\hline 146 & $2.305(5)$ & $\begin{array}{c}\mathrm{R}=\mathrm{Cl} \\
2.795(1)\end{array}$ & $\begin{array}{c}\mathrm{E}=\mathrm{O} \\
2.518(2)\end{array}$ & 89.1(1) & $\begin{array}{c}250.7, \mathrm{t} \\
{ }^{2} \mathrm{~J}_{\mathrm{C}, \mathrm{P}}=35 \mathrm{~Hz} \\
\left(\mathrm{C}_{6} \mathrm{D}_{6}\right)\end{array}$ & [73] \\
\hline 147 & $2.334(4)$ & $\begin{array}{c}\mathrm{R}=\mathrm{Cl} \\
2.836(1) \\
2.879(1)\end{array}$ & $\begin{array}{c}\mathrm{E}=\mathrm{O} \\
2.560(2)\end{array}$ & $90.5(1)$ & No data & [35] \\
\hline 148 & $2.327(3)$ & $\begin{array}{c}\mathrm{R}=\mathrm{S} \\
2.7090(9)\end{array}$ & $\begin{array}{c}\mathrm{E}=\mathrm{O} \\
2.671(2) 2.520(2)\end{array}$ & $84.96(8)$ & $\begin{array}{c}145.3 \\
(\mathrm{THF}-\mathrm{D} 8)\end{array}$ & [73] \\
\hline 149 & No RX data & & & & $\begin{array}{c}236.8, \mathrm{t} \\
{ }^{2} \mathrm{~J}_{\mathrm{C}, \mathrm{P}}=38 \mathrm{~Hz} \\
\left(\mathrm{C}_{6} \mathrm{D}_{6}\right)\end{array}$ & [73] \\
\hline 150 & No RX data & & & & $\begin{array}{c}231.8, \mathrm{t} \\
{ }^{2} \mathrm{~J}_{\mathrm{C}, \mathrm{P}}=37 \mathrm{~Hz} \\
\left(\mathrm{C}_{6} \mathrm{D}_{6}\right)\end{array}$ & [73] \\
\hline
\end{tabular}

In the case of the ethoxy substituted ligand the reactivity of plumbylene 146 was tested towards lithium diisopropylamide, lithium bis(trimethylsilyl)methanide and sodium thiophenolate to give the corresponding organolead(II) derivatives 148-150. ${ }^{[73]}$

\section{Conclusions}

Monoanionic pincer ligands, commonly used in the field of transition metal chemistry as a privileged platform due to their fine-tunable properties, have been intensively applied in organic synthesis, catalysis and material sciences. These types of ligands have more recently been employed for the stabilization of metallylenes, divalent species of group 14 elements, in order to exploit the particular structure of these species, with a lone pair of electrons and vacant $p$ orbital. Thus, monoanionic pincer ligands have been successfully used for the stabilization of stannylenes, germylenes and, more sporadically plumbylenes, however not yet of silylenes.

The peculiar structure of these ligands, with the flanking arms, containing $2 \mathrm{e}$ donor atoms, such as amino, imino, alkoxy, phosphonato, sulfonyl or sulfenyl groups, play an important role in the stabilization of the group 14 elements. The original reactivity of these compounds was highlighted, thus making it possible to imagine their applications in molecular chemistry. More recently, the development of asymmetric pincer systems, substituted by two different flanking arms, allows us to 
envisage a fine electronic modulation of the metallylenes by associating the hemilabile character of the ligand to the stabilization of the group 14 centre, for potential applications in catalysis.

\section{Acknowledgement}

This work was supported by the Centre National de la Recherche Scientifique (CNRS), the Université de Toulouse (UPS) and by Babeș-Bolyai University of Cluj-Napoca, by a grant of Ministry of Research and Innovation, CNCS - UEFISCDI, project number PN-III-P4-ID-PCE-2016-0351, within PNCDI III.

\section{References}

[1] W. P. Neumann, Chem. Rev. 1991, 91, 311-334.

[2] N. Tokitoh, R. Okazaki, Coord. Chem. Rev. 2000, 210, 251-277.

[3] Y. Mizuhata, T. Sasamori, N. Tokitoh, Chem. Rev. 2009, 109, 3479-3511.

[4] V. Y. Lee, A. Sekiguchi, Organometallic Compounds of Low-Coordinate Si, Ge, Sn and Pb, Wiley-VCH, Chichester, UK, 2010.

[5] The Privileged Pincer-Metal Platform: Coordination Chemistry \& Applications (Eds.: G. Van Koten, R. A. Gossage), Springer International Publishing, Cham, 2016.

[6] Organometallic Pincer Chemistry (Eds.: G. van Koten, D. Milstein), Springer, Berlin, Heidelberg, 2013.

[7] Pincer Compounds (Ed.:D. Morales-Morales), Elsevier, 2018.

[8] The Chemistry of Pincer Compounds (Eds.: D. Morales-Morales, C. Jensen), Elsevier Science, Amsterdam, 2007.

[9] D. Morales-Morales, Rev. la Soc. Química México 2004, 48, 338-346.

[10] R. Jambor, L. Dostál, in Organometallic Pincer Chemistry (Eds.: G. van Koten, D. Milstein), Springer, Berlin, Heidelberg, 2013, pp. 175-202.

[11] L. Dostál, R. Jambor, in Pincer Compounds (Ed.: D. Morales-Morales), Elsevier, 2018, pp. 47-65.

[12] M. P. Bigwood, P. J. Corvan, J. J. Zuckerman, J. Am. Chem. Soc. 1981, 103, 7643-7646.

[13] J. T. B. H. Jastrzebski, P. A. Van der Schaaf, J. Boersma, G. Van Koten, M. C. Zoutberg, D. Heijdenrijk, Organometallics 1989, 8, 1373-1375.

[14] C. Chuit, R. J. P. Corriu, A. Mehdi, C. Reyé, Angew. Chem. Int. Ed. 1993, 32, 1311-1313.

[15] K. Dannappel, M. Schürmann, B. Costisella, K. Jurkschat, Organometallics 2005, 24, 10311034.

[16] A. Bockholt, P. Jutzi, A. Mix, B. Neumann, A. Stammler, H.-G. Stammler, Z. Anorg. Allg. Chem. 2009, 635, 1326-1334.

[17] C. Bibal, S. Mazières, H. Gornitzka, C. Couret, Angew. Chem. Int. Ed. 2001, 40, 952-954.

[18] C. Bibal, S. Mazières, H. Gornitzka, C. Couret, Polyhedron 2002, 21, 2827-2834.

[19] S.-P. Chia, H.-X. Yeong, C.-W. So, Inorg. Chem. 2012, 51, 1002-1010.

[20] S. Khan, P. P. Samuel, R. Michel, J. M. Dieterich, R. A. Mata, J.-P. Demers, A. Lange, H. W. Roesky, D. Stalke, Chem. Commun. 2012, 48, 4890-4892.

[21] C. Seow, H.-W. Xi, Y. Li, C.-W. So, Organometallics 2016, 35, 1060-1063.

[22] N. Deak, P. M. Petrar, S. Mallet-Ladeira, L. Silaghi-Dumitrescu, G. Nemeş, D. Madec, Chem. Eur. J. 2016, 22, 1349-1354.

[23] N. Deak, O. Thillaye du Boullay, I.-T. Moraru, S. Mallet-Ladeira, D. Madec, G. Nemes, Dalton Trans. 2019, 48, 2399-2406.

[24] R. Chauvin, J. Phys. Chem. 1992, 96, 9194-9197.

[25] A. Bondi, J. Phys. Chem. 1964, 68, 441-451. 
[26] C. Bibal, S. Mazières, H. Gornitzka, C. Couret, Organometallics 2002, 21, 2940-2943.

[27] S. P. Chia, Y. Li, C. W. So, Organometallics 2013, 32, 5231-5234.

[28] N. Deak, I.-T. Moraru, N. Saffon-Merceron, D. Madec, G. Nemes, Eur. J. Inorg. Chem. 2017, 2017, 4214-4220.

[29] S.-P. Chia, E. Carter, H.-W. Xi, Y. Li, C.-W. So, Angew. Chem. Int. Ed. 2014, 53, 8455-8458.

[30] C. Seow, M. L. Bin Ismail, H.-W. Xi, Y. Li, K. H. Lim, C.-W. So, Organometallics 2018, 37, $1368-1372$.

[31] S. Khan, R. Michel, J. M. Dieterich, R. A. Mata, H. W. Roesky, J. P. Demers, A. Lange, D. Stalke, J. Am. Chem. Soc. 2011, 133, 17889-17894.

[32] M. Novák, M. Bouška, L. Dostál, A. Růžička, A. Hoffmann, S. Herres-Pawlis, R. Jambor, Chem. Eur. J. 2015, 21, 7820-7829.

[33] S. P. Chia, R. Ganguly, Y. Li, C. W. So, Organometallics 2012, 31, 6415-6419.

[34] M. Mehring, C. Löw, M. Schürmann, F. Uhlig, K. Jurkschat, B. Mahieu, Organometallics 2000, 19, 4613-4623.

[35] M. Henn, V. Deáky, S. Krabbe, M. Schürmann, M. H. Prosenc, S. Herres-Pawlis, B. Mahieu, K. Jurkschat, Z. Anorg. Allg. Chem. 2011, 637, 211-223.

[36] M. El Ezzi, R. Lenk, D. Madec, J.-M. Sotiropoulos, S. Mallet-Ladeira, A. Castel, Angew. Chem. Int. Ed. 2015, 54, 805-808.

[37] M. Aman, O. Mrózek, L. Dostál, Z. Růžičková, R. Jambor, J. Organomet. Chem. 2018, 872, $1-7$.

[38] M. Aman, L. Dostál, Z. Růžičková, S. Mebs, J. Beckmann, R. Jambor, Organometallics 2019, $38,816-828$.

[39] R. Jambor, B. Kašná, K. N. Kirschner, M. Schürmann, K. Jurkschat, Angew. Chem. Int. Ed. 2008, 47, 1650-1653.

[40] M. Bouška, L. Dostál, A. Růžička, L. Beneš, R. Jambor, Chem. Eur. J. 2011, 17, 450-454.

[41] M. Bouška, L. Dostál, F. de Proft, A. Růžička, A. Lyčka, R. Jambor, Chem. Eur. J. 2011, 17, 455-459.

[42] M. Bouška, L. Dostál, Z. Padělková, A. Lyčka, S. Herres-Pawlis, K. Jurkschat, R. Jambor, Angew. Chem. Int. Ed. 2012, 51, 3478-3482.

[43] T. Řičica, L. Střižík, L. Dostál, M. Bouška, M. Vlček, L. Beneš, T. Wágner, R. Jambor, Appl. Organomet. Chem. 2015, 29, 176-180.

[44] M. Bouška, M. Novák, L. Dostál, A. Růžička, T. Mikysek, R. Metelka, R. Jambor, Eur. J. Inorg. Chem. 2014, 2014, 310-318.

[45] M. Novák, T. Mikysek, A. Růžička, L. Dostál, R. Jambor, Chem. Eur. J. 2018, 24, 1104-1111.

[46] M. Bouška, J. Tydlitát, R. Jirásko, A. Růžička, L. Dostál, S. Herres-Pawlis, A. Hoffmann, R. Jambor, Eur. J. Inorg. Chem. 2018, 2018, 2038-2044.

[47] J. Martincová, L. Dostál, A. Růžička, J. Taraba, R. Jambor, Organometallics 2007, 26, 41024104.

[48] J. Martincová, R. Jambor, M. Schürmann, K. Jurkschat, J. Honzíček, F. A. Almeida Paz, Organometallics 2009, 28, 4778-4782.

[49] J. Martincová, R. Dostálová, L. Dostál, A. Růžička, R. Jambor, Organometallics 2009, 28, 4823-4828.

[50] M. Wagner, V. Deáky, C. Dietz, J. Martincová, B. Mahieu, R. Jambor, S. Herres-Pawlis, K. Jurkschat, Chem. Eur. J. 2013, 19, 6695-6708.

[51] J. Martincová, L. Dostál, A. Rủžička, S. Herres-Pawlis, R. Jambor, Z. Anorg. Allg. Chem. 2012, 638, 1672-1675.

[52] J. Martincová, L. Dostál, S. Herres-Pawlis, A. Růžička, R. Jambor, Chem. Eur. J. 2011, 17, $7423-7427$.

[53] R. Jambor, B. Kašná, S. G. Koller, C. Strohmann, M. Schürmann, K. Jurkschat, Eur. J. Inorg. Chem. 2010, 2010, 902-908.

[54] R. Jambor, S. Herres-Pawlis, M. Schürmann, K. Jurkschat, Eur. J. Inorg. Chem. 2011, 2011, 344-348.

[55] M. Novák, L. Dostál, Z. Růžičková, S. Mebs, J. Beckmann, R. Jambor, Organometallics 2019, 38, 2403-2407.

[56] L. Dostál, A. Růžička, R. Jambor, Eur. J. Inorg. Chem. 2014, 2014, 5266-5270. 
[57] B. Kašná, R. Jambor, M. Schürman, K. Jurkschat, J. Organomet. Chem. 2008, 693, 34463450 .

[58] R. Dostálová, L. Dostál, A. Růžička, R. Jambor, Organometallics 2011, 30, 2405-2410.

[59] R. Jambor, L. Dostál, A. Rủžička, I. Císařová, J. Brus, M. Holčapek, J. Holeček, Organometallics 2002, 21, 3996-4004.

[60] M. Mehring, M. Schürmann, K. Jurkschat, Organometallics 1998, 17, 1227-1236.

[61] M. Mehring, C. Löw, M. Schürmann, K. Jurkschat, Eur. J. Inorg. Chem. 1999, 1999, 887-898.

[62] M. Wagner, T. Zöller, W. Hiller, M. H. Prosenc, K. Jurkschat, Chem. Eur. J. 2013, 19, $9463-$ 9467.

[63] M. Wagner, M. Lutter, C. Dietz, M. H. Prosenc, K. Jurkschat, Eur. J. Inorg. Chem. 2015, 2015, 2152-2158.

[64] M. Wagner, K. Dorogov, M. Schürmann, K. Jurkschat, Dalton Trans. 2011, 40, 8839.

[65] M. Wagner, M. Henn, C. Dietz, M. Schürmann, M. H. Prosenc, K. Jurkschat, Organometallics 2013, 32, 2406-2415.

[66] M. Wagner, T. Zöller, W. Hiller, M. H. Prosenc, K. Jurkschat, Chem. Commun. 2013, 49, 8925.

[67] V. Deáky, M. Schürmann, K. Jurkschat, Z. Anorg. Allg. Chem. 2009, 635, 1380-1383.

[68] S. Krabbe, M. Wagner, C. Lo, C. Dietz, M. Schu, A. Ho, S. Herres-pawlis, M. Lutter, K. Jurkschat, Organometallics 2014, 33, 4433-4441.

[69] M. Henn, M. Schürmann, B. Mahieu, P. Zanello, A. Cinquantini, K. Jurkschat, J. Organomet. Chem. 2006, 691, 1560-1572.

[70] M. Wagner, C. Dietz, S. Krabbe, S. G. Koller, C. Strohmann, K. Jurkschat, Inorg. Chem. 2012, $51,6851-6859$.

[71] M. Wagner, C. Dietz, M. Bouška, L. Dostál, Z. Padĕlková, R. Jambor, K. Jurkschat, Organometallics 2013, 32, 4973-4984.

[72] S. P. Chia, H. W. Xi, Y. Li, K. H. Lim, C. W. So, Angew. Chem. Int. Ed. 2013, 52, 6298-6301.

[73] K. Jurkschat, K. Peveling, M. Schürmann, Eur. J. Inorg. Chem. 2003, 3563-3571. 